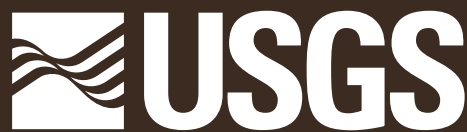

science for a changing world

Prepared under the auspices of the U.S. Agency for International Development

\title{
Geology, Water, and Wind in the Lower Helmand Basin, Southern Afghanistan
}

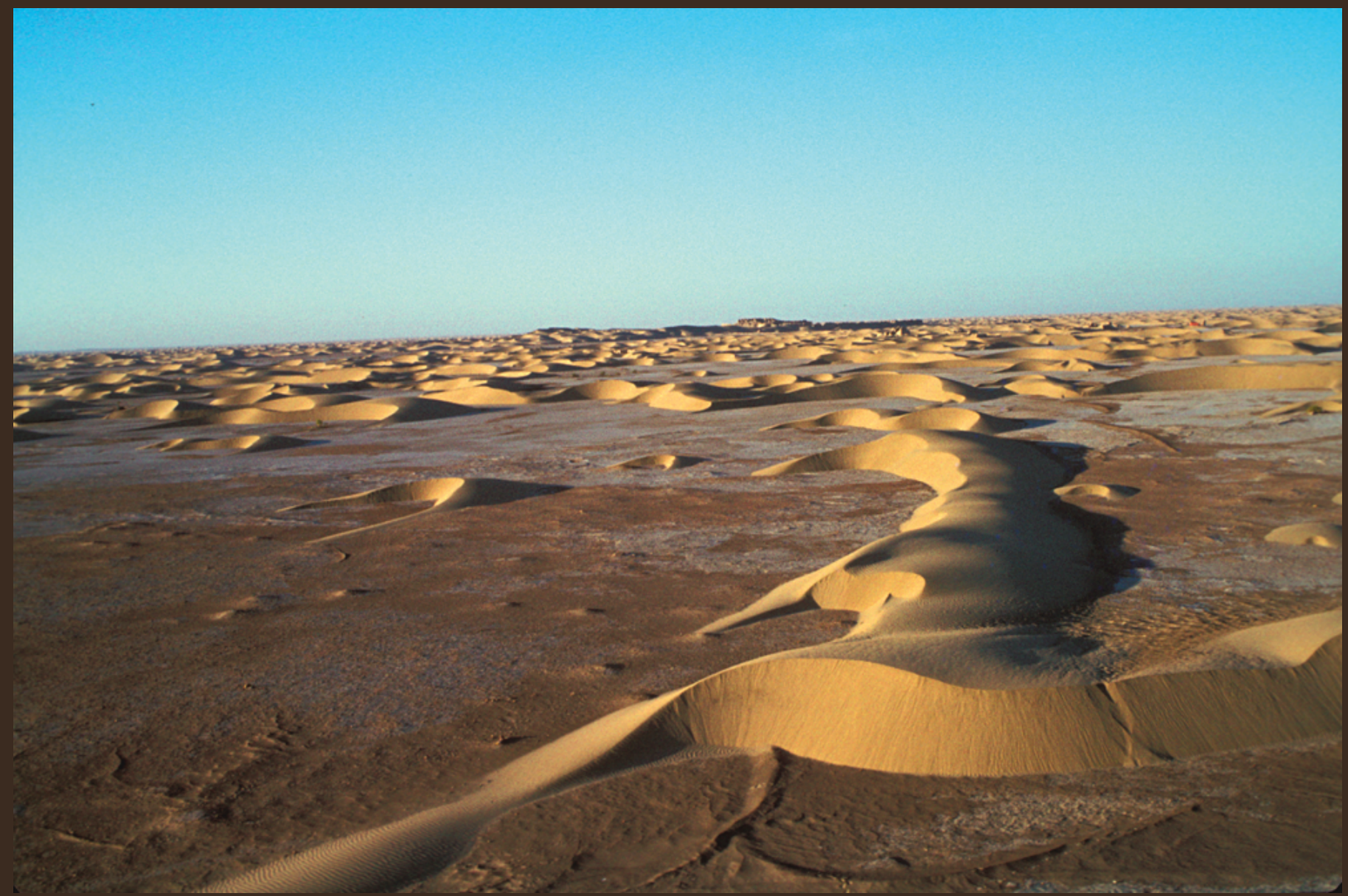

Scientific Investigations Report 2006-5182 
Cover photograph: Barchan dunes on the Sar-0-Tar agricultural plain, Sistan, Afghanistan. 


\section{Geology, Water, and Wind in the Lower Helmand Basin, Southern Afghanistan}

By John W. Whitney

Prepared under the auspices of the U.S. Agency for International Development

Scientific Investigations Report 2006-5182 


\section{U.S. Department of the Interior DIRK KEMPTHORNE, Secretary}

\section{U.S. Geological Survey \\ Mark D. Myers, Director}

U.S. Geological Survey, Reston, Virginia: 2006

For sale by U.S. Geological Survey, Information Services
Box 25286, Denver Federal Center
Denver, C0 80225
For more information about the USGS and its products:
Telephone: 1-888-ASK-USGS
World Wide Web: http://www.usgs.gov/

Any use of trade, product, or firm names in this publication is for descriptive purposes only and does not imply endorsement by the U.S. Government.

Although this report is in the public domain, permission must be secured from the individual copyright owners to reproduce any copyrighted materials contained within this report.

Suggested citation:

Whitney, J.W., 2006, Geology, water, and wind in the lower Helmand Basin, southern Afghanistan: U.S. Geological Survey Scientific Investigations Report 2006-5182, 40 p. 


\section{Contents}

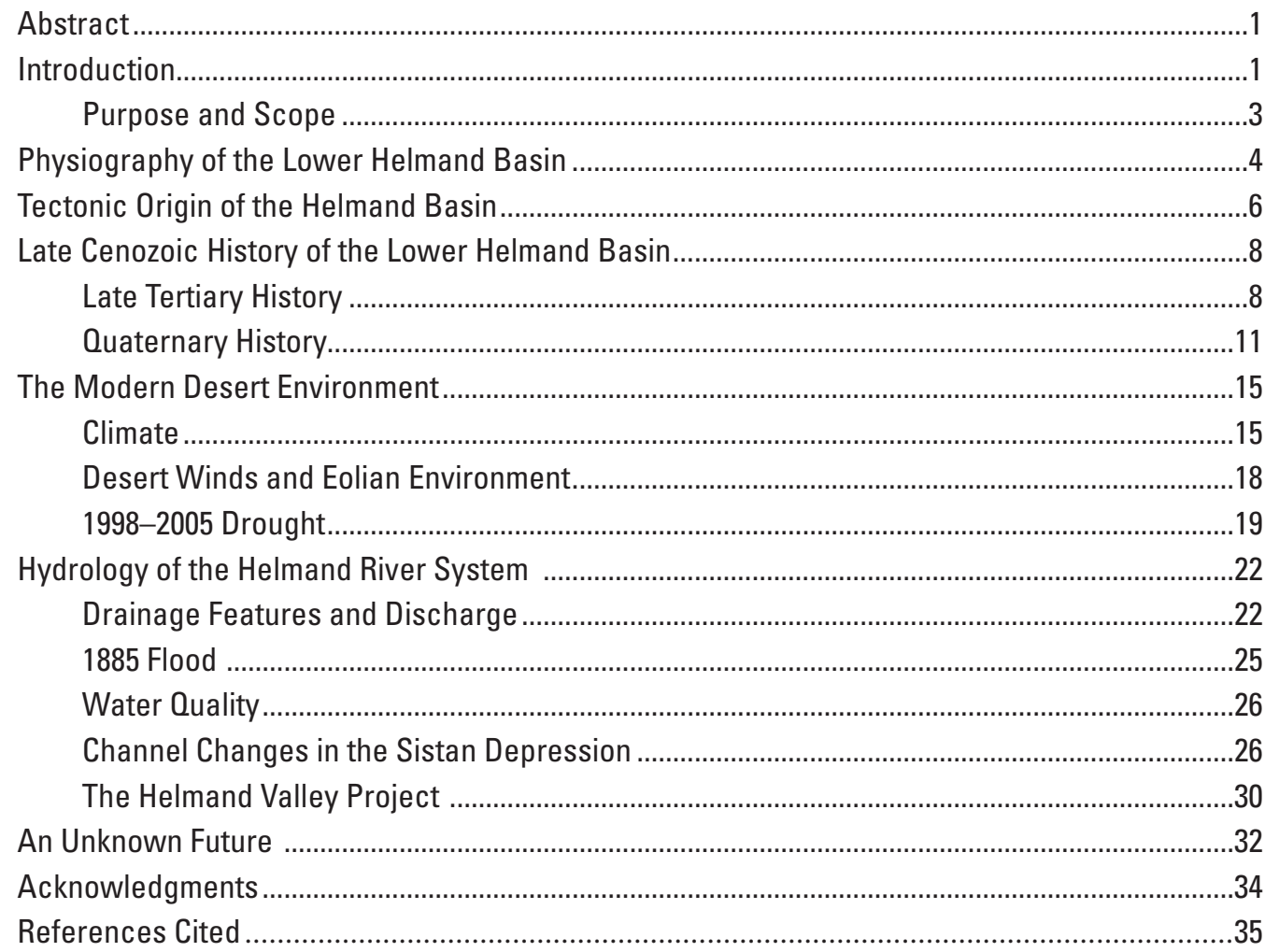




\section{Figures}

1. Landsat 5 image showing the lower Helmand Basin in southern Afghanistan.................2

2. Map showing geography of the lower Helmand Basin showing the location of physical features and streams.................................................................................

3. Map showing tectonic setting of the Helmand Basin and adjacent areas........................4

4. Photograph showing the two main stream terraces of the Helmand River downstream from the junction of the Arghandab and Helmand Rivers

5. Photograph showing multiple episodes of subsidence in the Sistan depression are recorded in the tilted basin-fill sediments (dipping to right) and uplifted erosional surfaces along the Afghan-Pakistan border near Jali Robat.............................

6. Geologic map of the lower Helmand Basin ...................................................................

7. Photograph showing a 13.6-meter-thick section of Sistan beds exposed south of Rudbar at the northern edge of the Gaud-i Zirreh ......................................................10

8. Map showing eolian deposits and wind directions in the lower Helmand Basin............13

9. Graph showing monthly and annual pan evaporation rates for the lower

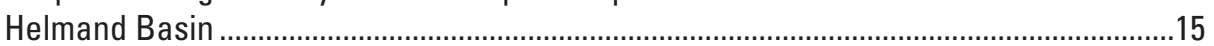

10. Climate diagrams for the Helmand Basin and adjacent areas .......................................17

11. Graph showing mean monthly wind velocities for Zaranj and Lashkar Gah ..................19

12. Photographs showing landsat images of the Sistan delta and hamuns in 1976 and 2001.

13. Photograph showing MODIS image (weather satellite) of dust deflation from the dry hamuns in Sistan on September 13, 2003.

14. Diagram showing stream profile of the Helmand River with mean annual discharges shown along the profile

15. Graphs showing monthly maximum, median, and minimum discharges of the Helmand River from the Kajakai Reservoir and of the Arghandab River from the Arghandab Reservoir

16. Graph showing average annual discharge of the Helmand River from the Kajakai Reservoir and of Arghandab River from the Arghandab Reservoir .....................24

17. Graph showing annual peak discharges of the Helmand River at Chahar Burjak ..........25

18. Map showing channel changes on the Helmand River delta in the Sistan depression

19. Map of agricultural lands irrigated by the Kajakai and Arghandab Dams of the Helmand Valley Project.

20. Photograph showing Kajakai Reservoir on the Helmand River in 1976.

21. Photograph showing a tamarisk band (a porous dam) on the Helmand River raises the water level in order to irrigate on the flood plain

22. Photograph showing a small village on the Helmand River flood plain near Qala-i Fath at the head of the delta is engulfed by dunes

\section{Table}

1. Calculations of flood discharges for the $1885,1903,1904$, and 1905 floods by T.R.J. Ward. 


\section{Conversion Factors}

\begin{tabular}{|c|c|c|}
\hline Multiply & By & To obtain \\
\hline \multicolumn{3}{|c|}{ Length } \\
\hline mile (mi) & 1.61 & kilometers (km) \\
\hline \multicolumn{3}{|c|}{ Area } \\
\hline acre & 4,047 & square meter $\left(\mathrm{m}^{2}\right)$ \\
\hline square foot $\left(\mathrm{ft}^{2}\right)$ & 0.09290 & square meter $\left(\mathrm{m}^{2}\right)$ \\
\hline \multicolumn{3}{|c|}{ Volume } \\
\hline cubic foot $\left(\mathrm{ft}^{3}\right)$ & 28.32 & cubic decimeter $\left(\mathrm{dm}^{3}\right)$ \\
\hline \multicolumn{3}{|c|}{ Flow rate } \\
\hline foot per second (ft/s) & 0.3048 & meter per second $(\mathrm{m} / \mathrm{s})$ \\
\hline cubic foot per second $\left(\mathrm{ft}^{3} / \mathrm{s}\right)$ & 0.02832 & cubic meter per second $\left(\mathrm{m}^{3} / \mathrm{s}\right)$ \\
\hline Multiply & By & To obtain \\
\hline \multicolumn{3}{|c|}{ Length } \\
\hline kilometer $(\mathrm{km})$ & 0.62 & mile (mi) \\
\hline meter $(\mathrm{m})$ & 3.28 & foot (ft) \\
\hline \multicolumn{3}{|c|}{ Area } \\
\hline hectare (ha) & 2.471 & acre \\
\hline square meter $\left(\mathrm{m}^{2}\right)$ & 10.76 & square foot $\left(\mathrm{ft}^{2}\right)$ \\
\hline \multicolumn{3}{|c|}{ Volume } \\
\hline cubic meter $\left(\mathrm{m}^{3}\right)$ & 35.31 & cubic foot $\left(\mathrm{ft}^{3}\right)$ \\
\hline cubic meter $\left(\mathrm{m}^{3}\right)$ & 264.2 & gallon (gal) \\
\hline \multicolumn{3}{|c|}{ Flow rate } \\
\hline meter per second $(\mathrm{m} / \mathrm{s})$ & 3.281 & foot per second $(\mathrm{ft} / \mathrm{s})$ \\
\hline
\end{tabular}

1 gallon per second $=646,316.9$ gallons per day

1 gallon per second for one year $=723.97$ acre-feet per year

1 cubic foot $=7.48$ gallons

1 million gallons $=3.07$ acre-feet

1 acre-foot $=1.233$ million liters $=1.233$ megaliters

Temperature in degrees Celsius $\left({ }^{\circ} \mathrm{C}\right)$ may be converted to degrees Fahrenheit $\left({ }^{\circ} \mathrm{F}\right)$ as follows: ${ }^{\circ} \mathrm{F}=\left(1.8 \times{ }^{\circ} \mathrm{C}\right)+32$

Temperature in degrees Fahrenheit $\left({ }^{\circ} \mathrm{F}\right)$ may be converted to degrees Celsius $\left({ }^{\circ} \mathrm{C}\right)$ as follows: ${ }^{\circ} \mathrm{C}=\left({ }^{\circ} \mathrm{F}-32\right) / 1.8$ 


\section{Southern Afghanistan Orthography (spelling of locations)}

\begin{tabular}{ll}
\hline Preferred (translation) & \multicolumn{1}{c}{ Other transliterations } \\
\hline Chahar Burjak & Char Burjak \\
Chankhansur & Chakansur \\
Dasht-i Margo & Dasht-e Margo, Daste Margo, Margo Desert, Margow Desert \\
Gaud-i Zirreh & Goud-e Zirreh, Gawd-e Zireh, Gowd-e-Zereh, Zirreh or Zereh Depression \\
Hamun (lake) & Hamoon, Hamoun \\
Hamun-i Helmand & Hamoon Hirmand, Daryacheh-ye Sistan \\
Hamun-i Puzak & Hamoon-e Puzak, Hamun-e Puzak, Hamoon-e-Puzak \\
Hamun-i Sabari & Hamoon-e Saberi, Hamoun-e Saburi, Hamun-e-Saberi \\
Harirud & Hari Rud \\
Helmand & Hirmand, Hilmand \\
Kabul & Kabol \\
Kajakai Dam & Band-e Kajakai \\
Kandahar & Qandahar \\
Koh-i Kannesin & Koh-e Khan Nassin, Koh-i Kannasin, Kuh-e Khannesin \\
Registan & Rigistan, Rigestan \\
Rud (river) & Rod \\
Sar-o-Tar & Tar-o-Sar \\
Shahr-i & Shahr-e \\
Shela Rud & Rud-e Shela, Rud-e Shelah, Shile River \\
Sistan & Seistan, Sejestan \\
Zabol & Zabul \\
& Hata
\end{tabular}

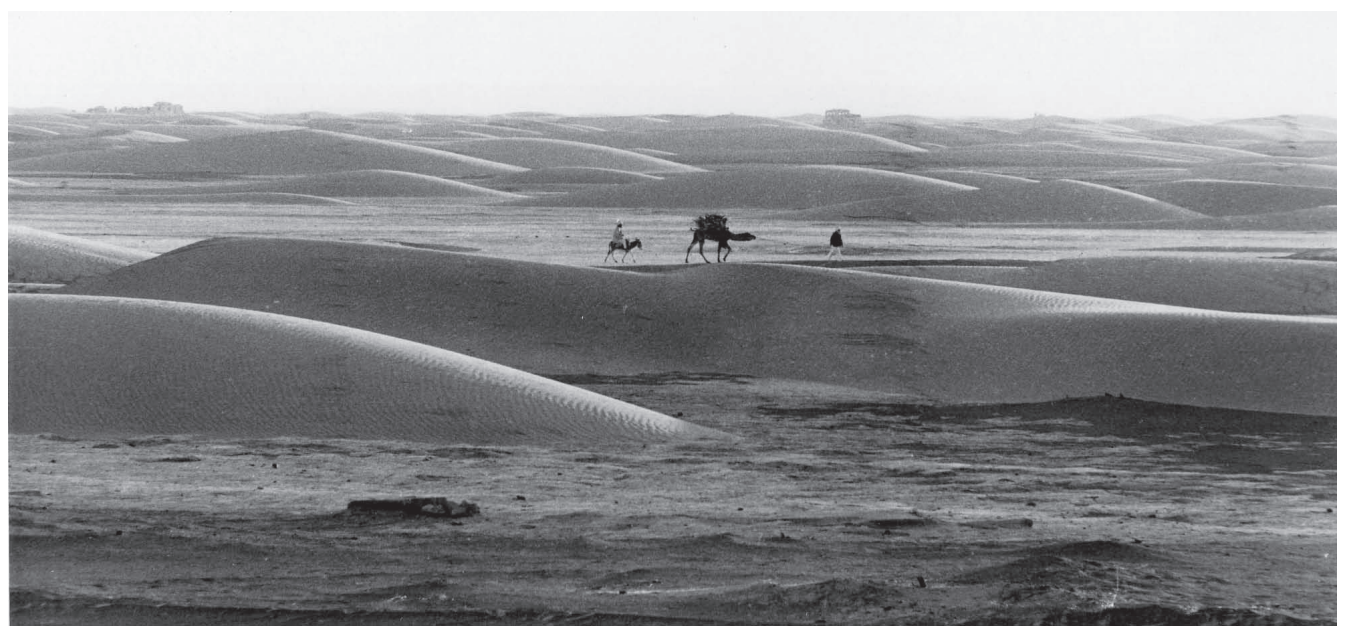




\title{
Geology, Water, and Wind in the Lower Helmand Basin, Southern Afghanistan
}

\author{
By John W. Whitney
}

\section{Abstract}

This report presents an overview of the geology, hydrology, and climate of the lower Helmand Basin, a large, closed, arid basin in southern Afghanistan. The basin is drained by the Helmand River, the only perennial desert stream between the Indus and Tigris-Euphrates Rivers. The Helmand River is the lifeblood of southern Afghanistan and has supported desert civilizations in the Sistan depression for over 6,000 years.

The Helmand Basin is a structurally closed basin that began to form during the middle Tertiary as a consequence of the collision of several Gondwanaland fragments. Aeromagnetic studies indicate the basin is 3-5 kilometers deep over basement rocks. Continued subsidence along basin-bounding faults in Iran and Pakistan throughout the Neogene has formed the Sistan depression in the southwest corner of the basin.

Lacustrine, eolian, and fluvial deposits are commonly exposed in the basin and were intruded by latest Miocene-middle Quaternary volcanoes, which indicates that depositional environments in the lower Helmand Basin have not substantially changed for nearly 10 million years.

Lakes expanded in the Sistan depression during the Quaternary; however, the size and extent of these pluvial lakes are unknown. Climate conditions in the lower Helmand Basin likely mirrored climate changes in the Rajasthan Desert to the east and in Middle Eastern deserts to the west: greater aridity during global episodes of colder temperatures and increased available moisture during episodes of warmer temperatures.

Eolian processes are unusually dominant in shaping the landscape in the basin. A strong wind blows for 120 days each summer, scouring dry lakebeds and creating dune fields from annual flood deposits. Nearly one-third of the basin is mantled with active or stabilized dunes. Blowing winds combined with summer temperatures over $50^{\circ}$ Celsius and voluminous insect populations hatched from the deltaic wetlands create an environment referred to as the "most odious place on earth" by 19 th century visitors. During dry years, large plumes of dust originating from Sistan are recorded by weather satellites.

The Helmand River drains about 40 percent of Afghanistan and receives most of its moisture from melting snow and spring storms. Similar to many desert streams, the Helmand and its main tributary, the Arghandab River, are characterized by large fluctuations in monthly and annual discharges. Water from the Helmand accumulates in several hamuns (shallow lakes) in the Sistan depression. The wetlands surrounding these hamuns are the largest in western Asia and are directly affected by droughts and floods on the Helmand. Average annual discharge on the Helmand is about 6.12 million megaliters (million cubic meters), and the annual discharge varies by a factor of five. In 2005, the region was just beginning to recover from the longest drought (1998-2005) of record back to 1830 . Annual peak discharges range from less than 80 cubic meters per second in 1971 to nearly 19,000 cubic meters per second in 1885. Large floods fill each hamun to overflowing to create one large lake that overflows into the normally dry Gaud-i Zirreh basin. The interaction of flooding, active subsidence, and wind erosion causes frequent channel changes on the Helmand delta.

A major development effort on the Helmand River was initiated after World War II with substantial aid from the United States. Two dams and several major canals were completed in the 1950s; however, poor drainage conditions on the newly prepared agricultural fields caused extensive waterlogging and salinization. New drains were installed and improved agricultural methods were implemented in the 1970s, and some lands became more productive. Since 1980, Afghanistan has endured almost constant war and civil and political strife. In 2005, the country was on a path to rebuild much of its technical infrastructure. Revitalization of agricultural lands in the lower Helmand Basin and improved management of surface- and ground-water resources are crucial to the country's reconstruction efforts.

\section{Introduction}

Sistan is the depression that receives the discharge of the Helmand River in the lower Helmand Basin and was often described by explorers, military men, and natural scientists of the 19th and early 20th centuries as one of the most desolate deserts on Earth. It still is. A large and remote desert basin, extremely arid and known for its windstorms, extreme floods, and droughts, the lower Helmand Basin in Afghanistan (fig. 1) is considered to be the easternmost extension of the Iranian Highlands. The closed basin receives the waters of the Helmand River, the only major perennial river in western Asia 


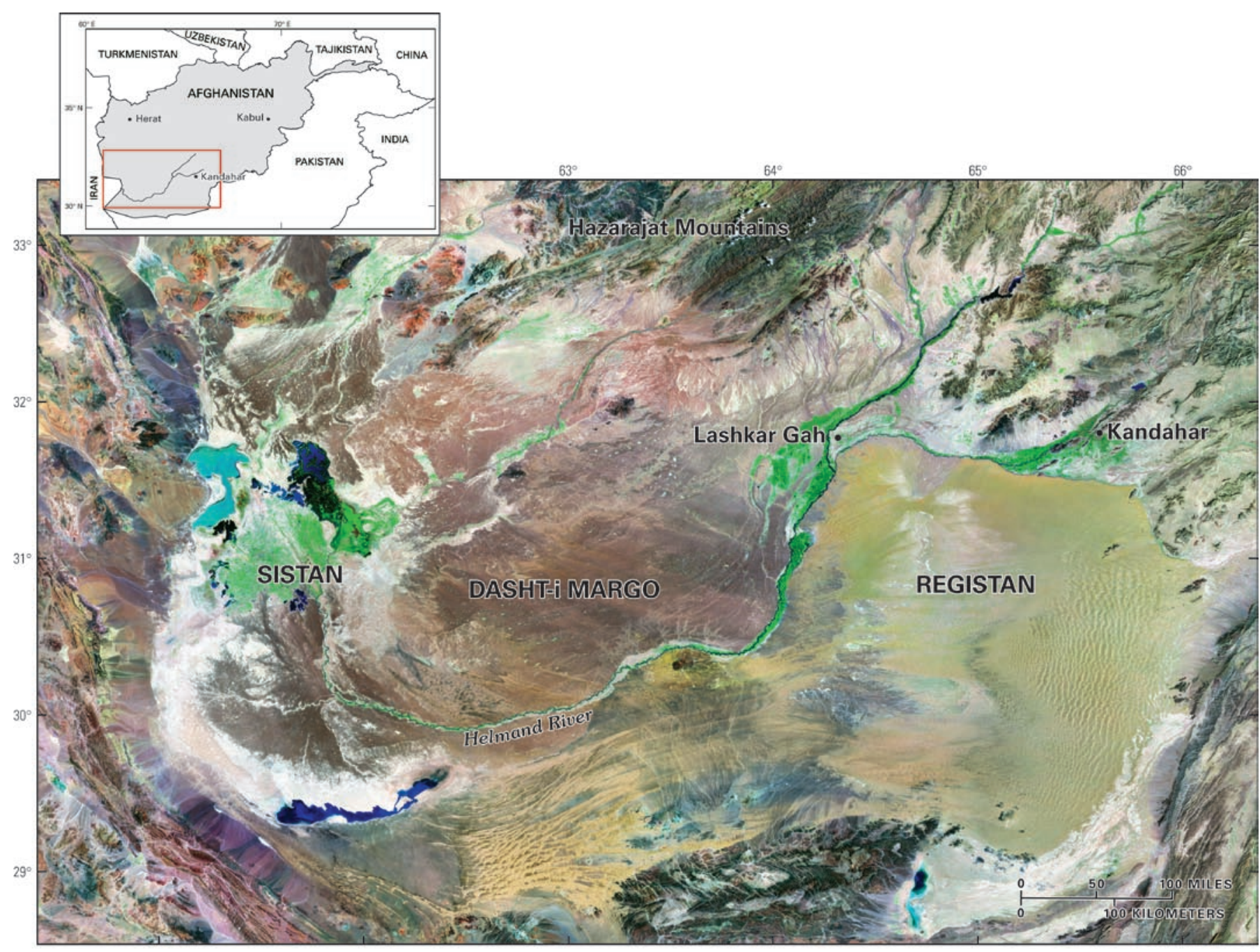

Figure 1. Landsat 5 image showing the lower Helmand Basin in southern Afghanistan.

between the Tigris-Euphrates and Indus Rivers. The Helmand and its tributary streams drain the southern Hindu Kush Mountains of Afghanistan and flow into an otherwise waterless basin of gravel plains and sandy tracts before terminating in Sistan (also Seistan, British spelling), a depression containing the large delta of the Helmand River and a series of shallow, semiconnected playas at the western edge of the basin (fig. 2).

Extensive archeological ruins in the Helmand Valley, on the Helmand delta, and around the terminal lakes are evidence that the Helmand River was a major focal point for the development of early civilizations in western Asia. In fact, archeological excavations at Shahr-i Sokhta (Tosi, 1973, 1976), located at the edge of the Hamun-i Helmand (hamun is a lake) (fig. 2), revealed that human societies developed rudimentary irrigation systems and lived in protourban settings by 3,200 B.C., several centuries before the great Harappan cities of the Indus Valley civilization appeared on the cultural horizon.

Sistan is known historically as the "breadbasket of western Asia" (Goldsmid, 1876). Agricultural civilizations have occupied the deltaic plains in Sistan intermittently and as late as the early $16^{\text {th }}$ century A.D. After the early $16^{\text {th }}$ century, Sistan has not been restored to its former prosperity. At present, a large field of active barchan dunes overlies most of the agricultural plain on the Afghan side of the Helmand delta. This plain was once the most prosperous and densely populated tract in the delta region.

In 1949 the United States initiated a new program for the improvement of underdeveloped areas of the world. The damming of the Helmand River in southern Afghanistan became one of the showcase projects of U.S. foreign aid in the "Third World" after World War II. Set up as the Helmand-Arghandab Valley Authority (HAVA), dams were built on the Helmand River and its main tributary the Arghandab River during the 1950s. The project goals were to provide hydroelectric power, increased agricultural productivity through irrigation, and land reclamation. The Arghandab dam, located northwest of the city of Kandahar, was completed in 1952 with a height of 145 feet (44.2 meters) and storage capacity of 388,000 acrefeet (478.6 million cubic meters). The larger Kajakai dam on the Helmand was completed a year later with a height of 300 feet (91.4 meters) and length of 919 feet (280 meters) and 


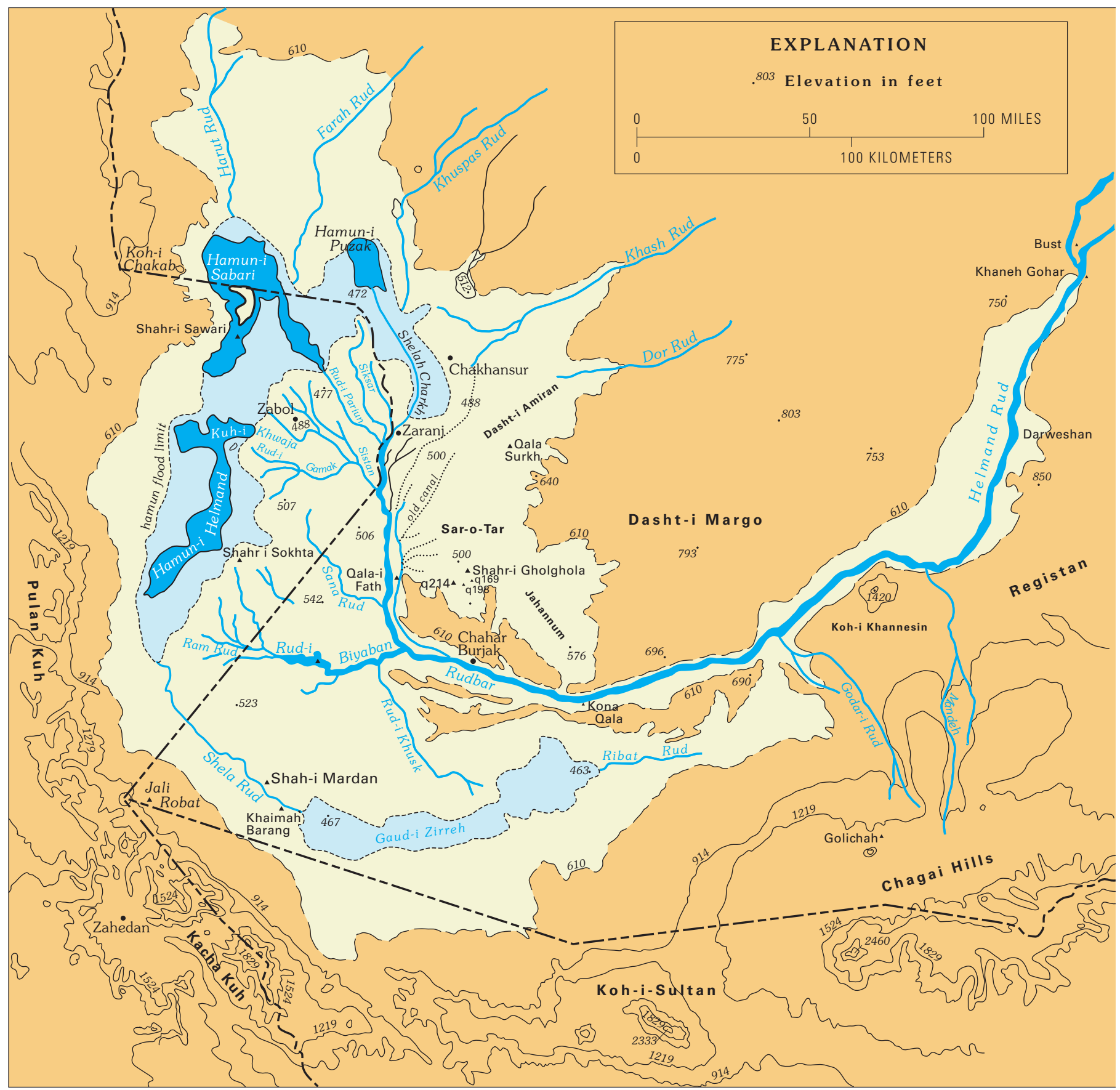

Figure 2. Geography of the lower Helmand Basin showing the location of physical features and streams.

storage capacity of $1,495,000$ acre-feet $(1,844$ million cubic meters). About 300 miles (482.8 kilometers) of concrete-lined canals were built to distribute the reservoir waters.

\section{Purpose and Scope}

This report presents a synthesis of the geology, climate, and surface hydrology in the lower Helmand River Basin as a foundation for future exploration and development of water and mineral resources. Very little technical work has been done in the region since the late 1970s. At that time, the Afghans (Mujahidin) began a protracted war and successfully repelled the Soviet occupation forces in 1988. In 1996, after years of civil war fighting among warlords, the Taliban, an alliance of Pashtun clans, captured Kabul and instituted a conservative Islamic regime. The Taliban ruled for 5 years until the American military invaded the country in response to the Taliban's accommodation and support of al Qaeda, an extremist Islamic group that has conducted international terrorism, including the attack on the World Trade Center in New York in 
2001. In 2005 Afghanistan continued slowly to rebuild, after more than two and a half decades of war, with its first elected government. Most of the country's infrastructure, including water resources, needs repair or restoration. Defining the oil and gas potential of the Sistan depression is also a 21 st century priority.

Field data presented in this report were collected from 1973 to 1977 when the author was a graduate student and a member of the Smithsonian Institution's archeological expedition to Sistan and the lower Helmand River region.

The Smithsonian's project ceased in dramatic fashion in 1979 when the Soviets invaded Kabul, and the American Ambassador, Adolf Dubs, was kidnapped and murdered. New technical information was added to this report in 2005 from available sources where possible.

\section{Physiography of the Lower Helmand Basin}

Afghanistan is a landlocked country composed of rugged mountain terrain, vast barren plains, and isolated basins. This harsh and remote landscape is dominated by the Hindu Kush Mountains, which are the western extension of the Karakoram-Himalayan mountain chain. The Hindu Kush ranges trend and generally decrease in altitude to the southwest from the Pamir Knot, a complicated mountain mass that formed where the northern tip of the Indian continental plate collided with the Russian plate (fig. 3). Nearly all the major mountain valleys follow faults or fault systems; earthquakes and multiple surfaces in these valleys are evidence of continuing uplift in these ranges.

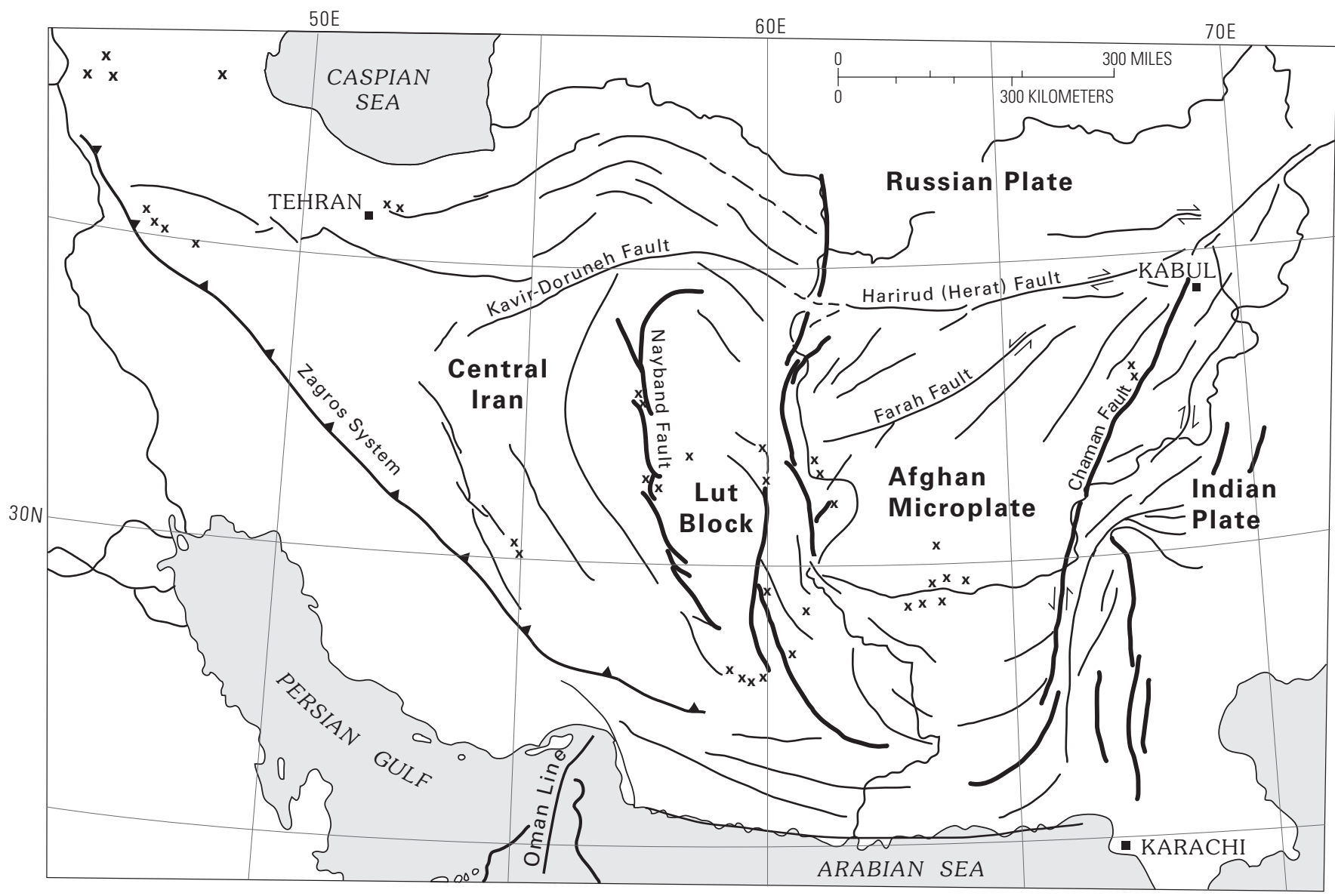

Figure 3. Tectonic setting of the Helmand Basin and adjacent areas. Major structural trends are shown and principal fault systems are labeled. Areas of volcanic activity shown by an "x." 
The Helmand Basin is approximately 310,000 square kilometers in area and drains about 40 percent of Afghanistan. Physiographically, it is the easternmost basin of the Iranian Highlands (Fisher, 1968). To the north, the basin is confined by the southern Hindu Kush ranges, on the west by the East Iranian ranges; and on the south and east by the mountain ranges in Baluchistan province of Pakistan. Culturally, the area south and west of the Kandahar-Lashkar Gah agricultural area is loosely referred to as being part of Baluchistan (also spelled Balouchistan, Baloochistan), a region that extends south and west into northwestern Pakistan and eastern Iran. The nearly 500 tribes, about 1.5 million people, who live in this region are culturally connected by the Baluchi (Balouchi) language.

The Helmand River (also spelled Hilmand, Hirmand) is the main stream in the basin (figs. 1,2) and its headwaters are in the high Koh-i Baba Range. The river begins its nearly 1,300-kilometer journey about 90 kilometers west of Kabul, then flows southwestward through steep, narrow valleys of the Hazarajat Mountains (fig. 1) before entering the vast, open basin that appears to the traveler as endless gravel plains with little relief (fig. 4); desert vegetation on these plains is limited to small depressions and areas where local runoff collects.

The Helmand River has several tributary streams whose headwaters are located in the eastern Hazarajat Mountains. The Tarnak and Arghastan streams flow into the Dor Rud (rud is Persian for river or stream), which in turn flows into the Arghandab River. The Arghandab joins the Helmand just downstream from the ancient site of Bust near the town of Lashkar Gah (figs. 1, 2). These tributaries would naturally contribute about 15-20 percent of the discharge received in the Sistan depression; however, most of the water is presently diverted for irrigation and domestic use (U.S. Agency for International Development, 1976).
The Helmand River is incised from 70 to 100 meters below the surface of the basin fill, and its valley width varies from 2 to 5 kilometers. As the river approaches the southwestern part of the basin, its direction curves sharply to the north as it enters the Sistan depression and terminates in several of the semiconnected lakes (the local term hamuns is used in this report) and wetlands that straddle the Afghan-Iran border. There are two principal stream terraces in the Helmand Valley (fig. 4); however, as many as four terrace remnants are found in the Koh-i Khan Nashin area, where the valley is wide. The highest terrace coincides with the top of the basin fill, and the main lower terrace, which is 20-30 meters above stream level, appears to be graded to an old delta of the Helmand River that is now incised by four distributary channels: the Sana Rud, Rud-i Biyaban, Rud-i Khusk, and the main channel (fig. 2; also see fig.19).

North of the Helmand Valley is the extensive Dasht-i Margo ("desert of death"), a remarkably flat and waterless plain that is broken up only by the shallow, southwestward-trending valleys of the Khash and Dor Ruds and several small fields of active dunes. South and east of the Helmand Valley is the Registan ("land of sand"), where a large, inactive sand sea has accumulated at the eastern edge of the basin. The inactive dunes are more than 75 meters high and strikingly red in color. Small, white-tan active dunes appear to be moving across the older stabilized dunes (Neil Munro, United Nations Environmental Programme consultant, written commun., 2005). Farther to the west in the Registan, the dunes are active, smaller in height, and lighter in color. Two other areas of active dunes are located in the Sistan depression: the Sar-o-Tar dunefield and the Gardan Reg. Parts of the Dasht-i Margo and much of the Registan have not been explored for scientific purposes except by aerial reconnaissance and remote sensing.

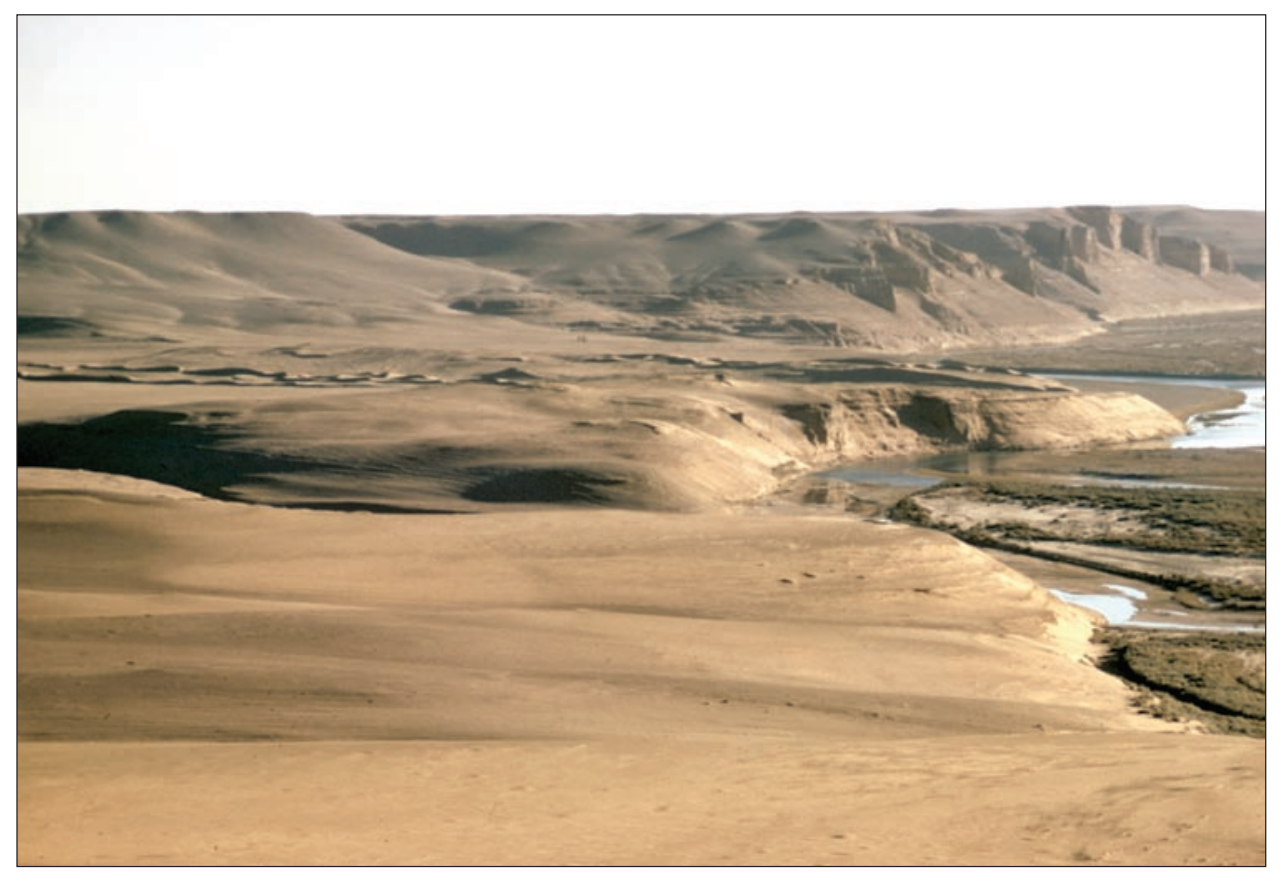

Figure 4. The two main stream terraces of the Helmand River downstream from the junction of the Arghandab and Helmand Rivers. Remnants of the upper terrace have been streamlined by wind erosion. 
Sistan is actually an 18,000-square-kilometer depression within the lower Helmand Basin. The floor of the depression, commonly called the Sistan Basin or Sistan Proper, is situated 200-300 m below the surface of the Dasht-i Margo and is occupied by the modern, arable Helmand delta and the terminal hamuns. Three main hamuns and wetlands are situated roughly at the termini of the deltaic distributary channels. Water in the hamuns is rarely more than 3 meters deep; in fact, during the 1970s local inhabitants still poled reed boats (called tutins) around the hamuns to fish and to harvest the reeds, which abound in the marshes (called naizar) that fringe most of the open-water areas. The size of the hamuns varies both seasonally and from year to year. Maximum expansion takes place in late spring, following snowmelt and spring precipitation in the mountains. All but 10 percent of the annual basin runoff enters Sistan between February and June. In years of exceptionally high runoff, the hamuns overflow their low divides and create one large lake that is approximately 160 kilometers long and 8-25 kilometers wide. Overflow from this lake is carried southward into the normally dry Gaud-i Zirreh (fig. 2), the lowest playa (463-meter altitude) in the Sistan depression. Mountain runoff varies considerably from year to year; in fact, the hamuns have completely dried up at least three times during in the 20th century. The maximum extent of the hamuns following large floods is shown in figure 2.

Several intermittent streams enter Sistan from the north and west. Runoff from the mountains in Iran and Pakistan percolates through the alluvial fans that rim the southwestern edge of Sistan. Runoff from the Paropamisus and western Hazarajat Ranges discharges into the northern hamuns through the Harut, Farah, Khash, and Khuspas Ruds. The combined discharge of all these sources (before irrigation diversion) is less than 20 percent of that contributed by the Helmand River (Brigham, 1964; U.S. Agency for International Development, 1976).

\section{Tectonic Origin of the Helmand Basin}

The Helmand Basin is a large, structurally closed basin that began to form during the middle Tertiary as a consequence of the collision of several former Gondwanaland fragments. Paleomagnetic studies in Afghanistan (Krumsiek, 1976, 1980) and in central Iran (Becker and others, 1973; Soffel and others, 1975) indicate that at least two, but probably more, continental fragments (referred to as microcontinents or microplates) broke away from the supercontinent Gondwanaland sometime during the Late Permian. These microcontinents drifted northward toward their present positions while rotating in a counterclockwise motion that is characteristic of Gondwanaland fragments. Collision of the Afghan microplate with the Eurasian continent, also called the Russian plate, was complete by Early Cretaceous and created the Paropamisus Range. This range forms part of the northern boundary of the Helmand Basin. Remnants of ocean floor and plate margins are exposed along complex suture zones near Kandahar and Farah in ophiolite complexes that are interlayered in Cretaceous limestones (Krumsiek, 1980).

The Kopet Daghah and Alborz Mountains in Iran were formed by a similar sequence of Alpine events: the Iranian microcontinents, assumed to be the Lut and Tabas blocks, collided northward with the Russian plate (Stocklin, 1974). The Alborz Mountains, however, have also been interpreted as a former volcanic island arc complex (Forster, 1978).

At about the same time (Early Cretaceous), or slightly earlier, the Indian plate broke away from Gondwanaland and began a 5,000-kilometer journey northward. Collision initiated with the Eurasian continental landmass sometime between the late Paleocene and the early Eocene (Molnar and Tapponnier, 1975; Klootwijk and Pierce, 1979). As the Indian plate continued northward, it converged westward against the Afghan and Iranian microcontinents. The amount of northward penetration of the Indian plate into Eurasia could be accommodated by tectonic thickening in the Asian mountain belts, or by underthrusting of continental crust; therefore, much of the crustal shortening took place by lateral movement of large crustal blocks away from the area of collision (Molnar and Tapponnier, 1975). Central and southwestern Afghanistan, the Afghan microplate (Afghan Block) including the Helmand Basin, is one of these wedge-shaped, crustal blocks and is shown in figure 3 .

The Afghan block is defined by two major wrench faults, the Chaman and Herat faults (fig. 3), that resulted from the crustal shortening on the west side of the Indian plate. The Chaman and Herat faults meet at a point about 70 kilometers north of Kabul and join the Ghorband-Panser fault, which continues northeast into the Pamir Mountains in Pakistan. The intersection of these three faults is a triple junction between the Russian, Indian, and Afghan-Iran crustal plates and blocks (Krumsiek, 1980). The Afghan block began displacement to the southwest during the late Eocene. This displacement has continued up to the present in response to continued northward thrusting of the Indian plate.

The 800-kilometer-long, north-south-trending Chaman (also called Moqur-Chaman) fault forms the eastern boundary of the Afghan block and is considered by Auden (1974) to be the transform fault that bounds the northwest edge of the Indian plate. The fault is active and is a principal source of earthquakes in Afghanistan (Abdullah, 1979). A major earthquake in 1892 displaced a set of railroad tracks by nearly a meter and created a surface rupture more than 200 kilometers long (McMahon, 1897). Based on the offset of isotopically dated volcanic rocks, a sinistral displacement rate of 2.5$3.5 \mathrm{~cm} /$ year for the last 2 million years has been calculated for movement on the Chaman fault (Beun and others, 1979).

The east-west-trending Harirud fault system forms the northern boundary of the Afghan crustal block (Wheeler and others, 2005). The fault extends more than 1,100 kilometers from northeast Afghanistan to Iran, where it may be connected with the Kavir-Doruneh fault system in Iran across a system of north-south fault systems that separates the Lut Block from 
the Afghan Microplate (also referred to as the Sistan Block) (fig. 3). Auden (1974) described the Harirud fault, then called the Herat fault (Wellman, 1966) before it was renamed by Russian geologists during the 1980s, as a fault system consisting of fault troughs containing deformed Neogene and Quaternary sediments. Trifonov (1978) reported offsets of 60-100 meters of probable Holocene-age fill along this fault, as well as similar displacements in Quaternary deposits in parallel fault valleys to the north. Wellman (1966) measured 60-100 m of dextral stream displacement along the fault north of Kabul. Holcombe (1978) has calculated an average rate of movement on the fault of 1.04 centimeters per year based on a total displacement of 620 kilometers along the Harirud fault.

Faults within the Afghan block are subparallel to, but do not exhibit displacements as great as, the Harirud and Chaman faults. Basic dikes along one of these internal faults, the Farah fault, are offset dextrally about 80 kilometers (Auden, 1974). The faults within the Afghan block exert structural control on the streams that drain into the lower Helmand Basin. Wheeler and others (2005) have compiled a seismotectonic map of Afghanistan and annotated bibliography on the basis of published sources and seismicity.

As the fault-bound Afghan block was squeezed southwestward away from India, the Afro-Arabian plate was moving to the north; the intervening regions in Iran were thus subjected to intensive collisional compression and deformation. The East Iranian ranges that form the west-to-southwest edge of the Helmand Basin were formed when western remnants of the former Tethys sea were closed and marine rocks as young as Eocene were intensely folded, faulted, and uplifted, while ultramafic rocks were tectonically emplaced into the marine sedimentary sequence. The intensity of this collision is seen in the zones of blueschist metamorphism that are found in these highly deformed rocks between the Afghan and Lut blocks (Stocklin and others, 1972).
The southwest-trending faults and mountain ranges in the Afghan block terminate abruptly against north-trending systems in Iran and the East Iranian ranges. This collision or suture zone between the Afghan and Lut block has been active since the late Eocene; dextral movement has been an apparent response to the continued movement of the Afro-Arabian plate (Forster, 1976, 1978; Freund, 1970). Late Tertiary-

Quaternary-age volcanoes erupted along the fault, and the fault is the locus of major earthquakes in eastern Iran (Gansser, 1971; Berberian, 1976).

The Sistan depression is situated at the junctions of the Harirud fault and the southwest-trending faults within the Afghan block. Middle to late Tertiary subsidence of basement blocks led to the formation of the lower Helmand Basin (Schreiber and others, 1971), and continued subsidence along the active Harirud fault has formed the Sistan depression during the late Tertiary and Quaternary (fig. 5). Ongoing movement of the Arabian plate from the southwest is recorded by continued seismic activity around the Iranian microplates (Berberian, 1976, 1981; Nowroozi, 1972, 1976).

Volcanic activity was also associated with the complex tectonic activity associated with the Afro-Arabian plate movement and closing of the Tethys sea (Forster, 1978). The Chagai Hills at the south edge of the lower Helmand Basin in Pakistan are, for example, one of the late Eocene volcanic fields that are found around the microcontinents. Volcanic flows and sills covered and intruded the Pliocene basin and lake sediments with olivine basalt and olivine dolerite in both Iran and the lower Helmand Basin (Gansser, 1971; Lang, 1971). A small, $7.3 \pm 0.2$ million-year-old basalt flow caps the 121-meter-high Kuh-i Khwaja mesa located in the Hamun-i Helmand (fig. 2) in Iranian Sistan (Jux and Kempf, 1983). This dated basalt flow overlies lakebeds, which indicates that the Sistan depression began to form, and lakes were present, in the Neogene,

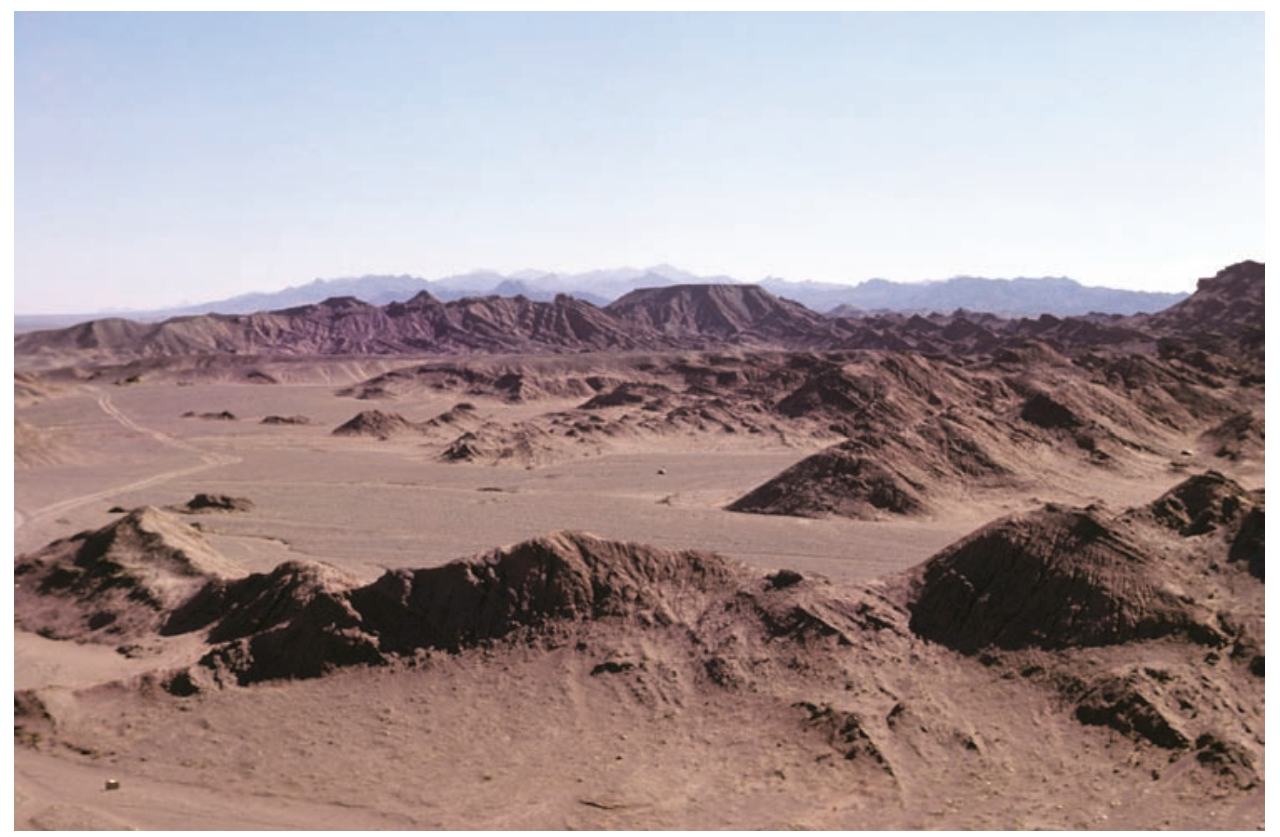

Figure 5. Multiple episodes of subsidence in the Sistan depression are recorded in the tilted basin-fill sediments (dipping to right) and uplifted erosional surfaces along the Afghan-Pakistan border near Jali Robat. View to the east. 
although the original flow surface has probably subsided an unknown amount since deposition.

The most recent episode of widespread volcanic activity took place during the Pliocene and early Quaternary, when the Zagros Mountains of western Iran were formed from severe compression and uplift due to the northeast rotation of the Arabian plate. Three large volcanoes, Koh-i Sultan, Koh-i Taftan, and Koh-i Bazman, are located just south of the lower Helmand Basin and lie in a southwesterly trend just south of the border with Pakistan (fig. 4). The Quaternary-age volcanic rocks intruded into folded Eocene melange as well as older eroded volcanic complexes. These young volcanic centers still show signs of activity, although no historical flows are known. The Quaternary lavas are more intermediate to silicic in composition than the Eocene lavas. The line of these volcanoes does not follow the strong structural surface trends of the region, which may point to the existence of large discrepancies between the surface and deeper subsurface structures (Gansser, 1971).

One isolated volcano, Koh-i Khannesin, in south-central Helmand Basin is situated on the south bank of the Helmand River (fig. 2). It is a carbonatite volcano and apparently is unrelated to the Koh-i Sultan complex located to the southwest or to the older Chagai Hills located directly to the south (Abdullah and others, 1975). Although Koh-i Khannesin was considered Pliocene to early Quaternary in age because of the eroded appearance of the crater (Vikhter and others, 1978), a lava flow on the southeast flank of the volcano erupted during the middle Quaternary. A potassium-argon (K-Ar) date of $0.61 \pm 0.05$ million years was obtained on leucite crystals separated from a collected sample of a leucite phonolite (Richard Marvin, U.S. Geological Survey, written commun., 1977). The flow appears to be one of the youngest flows from the volcano; the center of the crater is now highly eroded. Afghan and Russian geologists discovered rare-earth metals associated with the volcanic rocks at Koh-i Khannesin (Shareq and others, 1977; Shareq, 1981) and evaluated the economic potential of the mountain.

\section{Late Cenozoic History of the Lower Helmand Basin}

The upper Cenozoic deposits of the lower Helmand Basin are shown in figure 6 , which is a geologic map of the basin revised after Wittekindt and Weippert (1973) on the basis of fieldwork, interpretation of Landsat images, and recent geologic map compilations by O'Leary and Whitney (2005a, b). Basin stratigraphy is dominated by three units: the Sistan beds, coarse gravels that overlie the Sistan beds, and eolian sands. Eolian sand distribution is controlled by the locations of flood sands, which are reworked by northwesterly to westerly winds. The distribution of coarse gravels on the Dasht-i Margo reflects the deposition of coarse debris off the southern Hazarajat Mountains, which lie just to the north of the map area. The Sistan beds are exposed where stream incision and scarp retreat have undercut or eroded away colluvium and (or) overlying gravels.

Younger gravel deposits are chiefly distributed along the basin edge or adjacent to volcanic mountains; generally, these gravels underlie pediments and alluvial fans. A few loess deposits generally are present near the stream valleys and on some of the mountain hillslopes that border the basin. Modern lacustrine deposits are present around the hamuns in the Sistan depression.

\section{Late Tertiary History}

Late Tertiary basin sedimentation was controlled primarily by late Tertiary subsidence of basement blocks, by the supply of detritus from the surrounding mountains, and by the Neogene climates that controlled transport processes in the basin. Sedimentation patterns in the basin are predictably similar to other Asian intermontane basins: coarser grained sediments are deposited closer to the edge of the basin, and fine-grained sediments are deposited in the lower reaches of the basin (Blanford, 1873; Dickey, 1968). The exact patterns of sedimentation in any closed basin are dictated by the number and position of streams and local base levels or depressions. The depressions are controlled by the location and activity of the major basin-controlling faults (Reeves, 1977).

The depositional history of the lower Helmand Basin is imprecisely known because little detailed fieldwork has been done on the stratigraphy of this remote area, and subsurface geologic data are not available. All earlier investigators, including this author, have either studied one area in some detail or several outcrops across widely separated localities.

Aeromagnetic surveys (Schreiber and others, 1971) indicate that the sediment thickness above the Precambrian basement blocks varies from 3,000 meters to more than 5,000 meters. Basin deposition likely began following Oligocene subsidence; Neogene and Quaternary sediment thickness is estimated to be approximately 1,000 meters (Weippert and others, 1970) and is believed to be greater near the western edge of the basin where subsidence has continued to the present. However, only the uppermost 250 meters of sediment is exposed along the cliffs of the lower Helmand Valley and Sistan depression. The exposed stratigraphy is remarkably uniform and flat-lying except along the Iranian and Pakistani mountain fronts. In fact, the horizontal aspect and apparent continuity of individual beds led some investigators to believe that tectonic activity played only a minor role in the depositional history of the basin (Blanford, 1873; Huntington, 1905; Jux and Kempf, 1983; Smith, 1974).

The Neogene basin fill is composed of two informal units: the Sistan beds (Lang, 1971; Jux and Kempf, 1983), which consist chiefly of fluvial and eolian sand units and lacustrine sandy and clayey silts; and beds of coarse to fine gravels, which overlie and, near the basin edge, interfinger with the Sistan beds. The cliffs around Sistan expose nearhorizontal lake and fluvial units of the Sistan beds; however, 

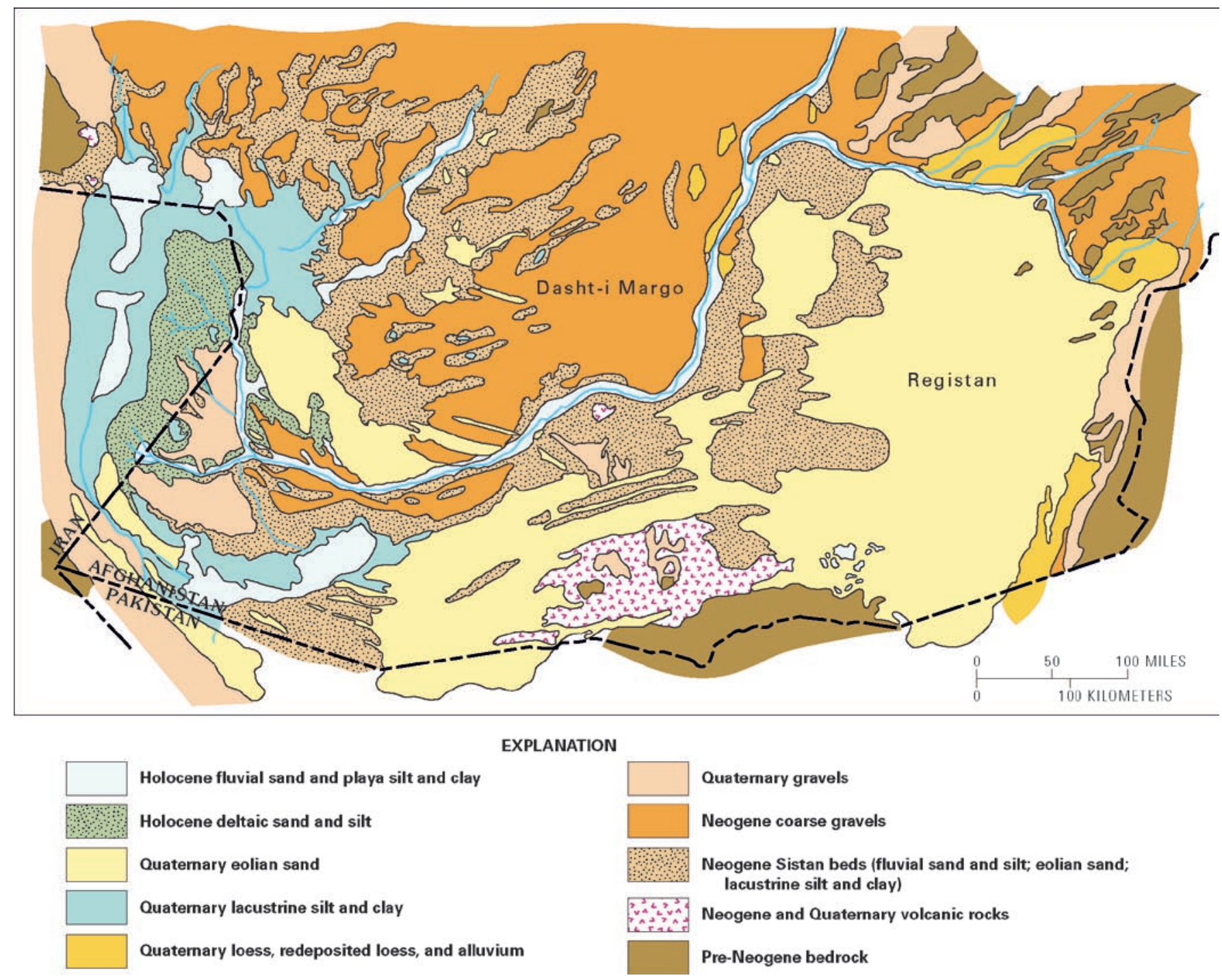

Figure 6. Geologic map of the lower Helmand Basin. Revised from Wittekind and Weippert (1973) and O'Leary and Whitney (2005a, b).

it is not known how deep these deposits extend. The overlying gravels vary from less than a meter to more than 15 meters thick and were deposited on an erosional surface.

The Sistan beds exposed along the northern edge of the Sistan depression consist mainly of flat-lying, alternating units of oxidized (tan to pink) and unoxidized (light green) clayey silt. Fluvial sand units also are present in outcrops visited in the Helmand Valley and Gaud-i Zirreh. The presence of these lakebeds led several investigators to hypothesize that the entire lower Helmand Basin was at one time filled by a very large lake. Furthermore, the age of the lake was assumed to be Pleistocene because of the position of beds at the top of the basin fill and the known worldwide fluctuations in Quaternary climate (Anderson, 1973; Blanford, 1873; Huntington, 1905; Smith, 1974).

The existence of a Pleistocene basinwide lake is unlikely for two reasons. First, the thick lacustrine deposits are confined to exposures in the western one-third of the lower
Helmand Basin, and second, the dated Neogene volcanic rocks in the Sistan beds indicate deposition primarily during the Neogene. Exposed Sistan beds along the Helmand Valley from Lashkar Gah to the Rudbar area consist chiefly of eolian and fluvial sands that contain rare, thin, interbedded units of tuff (Lang, 1971). Between Koh-i Khannesin and Chahar Burjak, the number of interbedded, 1- to 3-meter-thick lakebeds increases from one to two, or to possibly three; the rest of the exposed section is eolian and fluvial sand. At the western edge of the Dasht-i Margo at a location east of the Sar-o-Tar archeological plain, a 97-meter section of the Sistan beds was measured that consists of 88 meters of crossbedded sands and 7 meters of gypsiferous lacustrine silt. At the top of the section is 2 meters of well-rounded gravel. South of the Helmand River, the cliffs along the north edge of the Gaud-i Zirreh are composed chiefly of fluvial and eolian sands with one interbedded lacustrine unit (fig. 7). Thus, the exposed Sistan beds located outside the Sistan depression indicate that the principal 


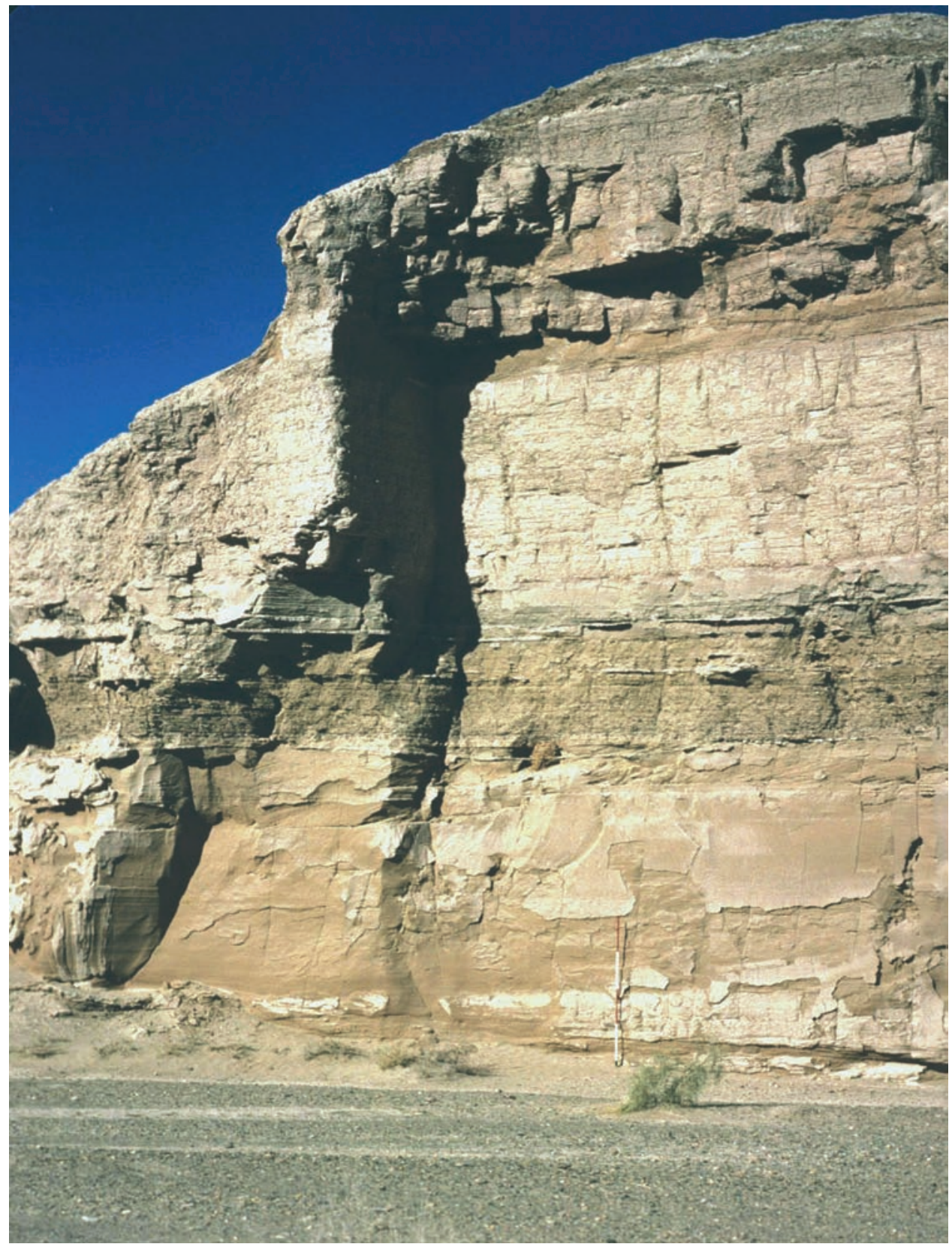

Figure 7. A 13.6-meter-thick section of Sistan beds exposed south of Rudbar at the northern edge of the Gaud-i Zirreh. The four principal units from bottom to top are eolian sand, fluvial sand with mud chips, fluvial sand, and lacustrine silt. A 2-meter scale is at the cliff base.

depositional environments were eolian and fluvial; lacustrine deposition was infrequent and short-lived. Without close topographic and lithologic control, it is impossible to tell whether or not the few lacustrine beds located outside the depression were deposited in isolated lakes or in a lake that expanded from the Sistan depression.

A major problem in describing the stratigraphy of the Sistan beds is the lack of index fossils and marker beds. Jux and Kempf (1983) identified ostracods from the lacustrine units exposed just north of the hamuns and found that the species indicate an indeterminate age of Neogene to Pleistocene. The ostracods, however, do indicate that the chemistry, depth, and temperature of the lakes at that time were similar to conditions in the present hamuns. These paleoenvironmental data correlate well with the arid climatic conditions that are inferred from the eolian sand units in the Sistan beds exposed outside the Sistan depression. In fact, the crossbedding directions in the sand units suggest that sand deposition took place under a wind regime similar to present conditions (Lang, 1971; Smith, 1974).

The gravels overlying the Sistan beds are a puzzlement because the surfaces of deposition appear to have gradients 
that are too low for gravel transportation. Smith (1974) proposed that the mode of deposition was by pebbly mudflows. However, Jux and Kempf (1983) observed that the gravels increase in thickness toward the mountains and interfinger with mountain-front fans. Gravel outcrops commonly display fluvial crossbedding that indicates fluvial deposition. Jux and Kempf reported a 50-meter-thick channel deposit of gravel near Koh-i Chakab, located in Iranian Sistan west of the north end of Hamun-i Sabari, which the authors believed was deposited in response to an episode of subsidence in the Sistan depression.

The gravel cover on the surface (dasht) of the basin fill most likely has a complex depositional history. Gravels were deposited by streams from the Hazarajat Mountains that flowed across the gentle Dasht-i Margo plain before the Sistan depression and present Helmand Valley were formed. The deposition of gravel instead of finer grained sediment may have been in response to relatively rapid uplift in the mountains or to increased runoff due to climatic change, or possibly to both factors. The gravel was probably distributed unevenly on the surface, and subsequent reworking and surface erosion, including strong deflation, over a long time period has formed a lag gravel cover over most of the Dasht-i Margo. The local reworking of gravel deposits would explain the fact that gravels are very thin or absent in some places and 1-3 meters thick in other places. Pias (1976) noted thick gravel deposits west of the present Helmand Valley that he believed were deposited by the Helmand River before the present valley was incised.

Reworking of gravel by local runoff continued in the lower Helmand Basin long after the Helmand River incised into the basin fill. In fact, most, if not all, of the gravel found on all surfaces below the Dasht-i Margo has been reworked from the gravels that were originally deposited on top of the Sistan beds. The gravel is transported to lower surfaces by slope retreat processes that leave behind a lag deposit and by local runoff. In Sistan, it is common to see concentrations of gravel at multiple levels on the eroding slopes of the Sistan beds; each gravel concentration represents the position of a former runoff channel. Pebble counts on three different surfaces at Chahar Burjak by Jux and Kempf (1983) illustrate this principle well; the percentage of limestone pebbles decreased from 15 percent on the highest surface to 6.5 percent on the middle surface to 1 percent on the lowest surface, while the percentage of resistant quartz pebbles had a corresponding increase from higher to lower surfaces.

The Sistan beds and overlying dasht (surface) gravels have been intruded by volcanic rocks at Koh-i Khannesin, Kuh-i Khwaja, and Koh-i Chakab, volcanoes located along the western edge of Sistan in Iran (fig. 6). Koh-i Khannesin is reported to be between 1.4 and 2.8 to 5.0 million years old by Shareq and others (1977), although the methods of dating were not given. Jux and Kempf (1983) obtained whole rock, potassium-argon ages of $7.3 \pm 2$ million years and $8.2 \pm 6.0$ million years on basalt from Kuh-i Khwaja and Koh-i Chekab. These age determinations may be somewhat older than the rocks due to argon loss or because lavas were contaminated slightly by older rock; however, the ages of all three volcanic eruptions indicate that the underlying Sistan beds and gravels are Neogene.

The late Miocene age of Kuh-i Khwaja, a basalt flow that overlies lakebeds, also indicates that the Sistan depression existed by that time. The base of volcanic flow is situated only 55-60 meters above the present lake plain, whereas the depression is about 255 meters deep. Assuming the late Miocene age determination is correct, the Sistan depression was about 200 meters deep and the Helmand Valley was established when the upper Miocene lava was deposited. However, it is unlikely that the Helmand was incised to its present depth before the middle Pleistocene because more than 35 meters of downcutting has taken place below the $0.6 \pm 0.01$ millionyear-old leucite phonolite flow at Koh-i Khannesin. The total depths of the depression and resultant valley incision are not known because of the unknown sediment thickness underlying the delta and hamuns in Sistan.

\section{Quaternary History}

The Quaternary history of the lower Helmand Basin is primarily recorded in the Helmand Valley and Sistan depression because the top of the basin fill has been an erosional surface since the deposition of Neogene gravels above the Sistan beds. Quaternary deposition outside the valleys and depression was chiefly confined to gravel deposition at the mountain fronts and to dune accumulation in the Registan. Fluvial and lacustrine deposition in the Sistan depression and inflowing valleys has been continuous from the late Tertiary to the present, although the patterns of deposition and erosion were controlled by local tectonic movements and by fluctuating climatic conditions. No stratigraphic break between the Tertiary and Quaternary deposits has been identified in the Sistan depression. A lack of age control is the principal impediment to deciphering Quaternary history in the basin. The major reason for few dated deposits is that several dating methods available in 2005 were not available in the 1970s when these studies were conducted: luminescence dating, which would be well suited for eolian sands and lake silts; cosmogenic dating, useful for determining exposure ages; and uranium-series dating, which can now be used to analyze ages of soil carbonates. Until a clear distinction is drawn between the Neogene and Quaternary sediments underlying the delta and conterminous lake basins, reconstruction of the early and middle Quaternary basin history is imprecise. Available data for a climatic reconstruction of the late Quaternary in Sistan are few; thus, the climatic framework presented here is heavily based on correlations with better dated stratigraphic sequences in Iran and India.

In an attempt to define the Tertiary-Quaternary boundary in Sistan, Jux and Kempf (1983) obtained three 9-meter-long cores from the dry lakebeds of the Hamun-i Sabari and the Hamun-i Puzak (fig. 2) during the 1971 drought. Gastropods, ostracods, and pelecypods collected from the cores characterize a lacustrine environment of generally fresh or slightly 
brackish water. Jux and Kempf argued that the Quaternary lake deposits must be very thin, in some places less than 5 meters, because of the presence of one ostracod, Cyprideis torosa, which predominates in the lower sections of the cores but is absent in the upper sections. This species is associated with brackish water conditions and is a common ostracod in the Neogene Sistan beds that are exposed in the nearby cliffs. The species Cyprideis torosa, however, is alive at present (present, for example, in the Dead Sea). Therefore, the presence of the species cannot be considered an indicator of Neogene-age sediments, nor can the species be said to live in an environment that does not exist in Sistan today (I.G. Sohn, U.S. National Museum, written commun., 1976). Jux and Kempf did not consider an alternative explanation that Quaternary fluctuations in lake size and changing lake positions may account for fluctuating conditions of sedimentation and salinity. The thickness of Quaternary deposits in the present lakebeds cannot be determined on the presence or absence of one species of ostracod that has persisted from the early Neogene to the present; thus, the thickness of Quaternary fill is still an open question.

Ellsworth Huntington (1905) was the first investigator to describe a Quaternary history in the Sistan depression. Although he was limited to fieldwork in Iranian Sistan and did not visit the Helmand Valley, he proposed that the exposed pink and green lacustrine sediments resulted from alternate expansions and contractions of a large lake in Sistan controlled by Quaternary climatic fluctuations. Huntington calculated that 10 pluvial-to-arid cycles, interrupted by an episode of volcanic activity, would account for nearly all the observed features present in the Sistan basin. Huntington also noted that distorted shorelines were evidence that warping (deformation) has continued to recent times; however, the influence of tectonic activity was all but excluded from Huntington's geologic reconstruction of the basin. From a historical point of view, a major objective of the 1900 Carnegie Expedition, which also included noted American geographers Raphael Pumpelly and W.M. Davis, was to expound on the nature of climatic changes in Central Asia. Thus, Huntington's climatic reconstruction was almost certainly influenced by his earlier observations in the glaciated drainage basins in Turkestan.

Huntington did perceive and discuss alternative geological mechanisms to account for the rhythmic nature of the stratigraphic units. He considered a "diversion" theory whereby a river was diverted back and forth across a basin and concluded that such behavior must be due to a systematic cause such as warping or climatic change. He decided that rhythmic warping was implausible and could not account for the exposed lake sediments as well as a climatic mechanism that would cause the hamuns to expand and contract. Had Huntington known that the Sistan beds were Neogene in age instead of Pleistocene, perhaps he might have more strongly considered his tectonic model of basin sedimentation.

Because of the lack of dating control on the Sistan beds, Smith (1974) also assumed that all exposed deposits in the Helmand Basin are Quaternary in age. He stated that basin sediments rest on deformed strata of Koh-i-Khannesin, the extinct volcano south of the Helmand River, and that the eroded mountain is likely to be early or middle Tertiary in age. Although Smith allowed that faulting may have occurred at the west edge of the basin, he hypothesized that the Sistan depression was formed almost entirely by deflation; the mountains at the southern edge of the basin deflected northwesterly winds to the east, which caused increased turbulence in the area of the Gaud-i-Zirreh depression. Although not stated explicitly, Smith implied that the deflation must have taken place during dry interglacial intervals of the Pleistocene because the Sistan hamuns would have expanded during glacial times of lower mean annual temperatures.

The idea of accelerated wind erosion during an interglacial climate was first applied in Iran by Bobek $(1963,1969)$ to explain a large field of yardangs (positive-relief landforms carved by wind erosion) in the Lut Basin. Bobek, however, believed that the magnitude of climatic changes was much smaller in the arid basins of eastern Iran than in northern and western Iran; otherwise, the Lut yardangs would have been altered or destroyed by either runoff or lake deposition during significantly wetter conditions.

The existence of large, basinwide Quaternary lakes, as proposed by Huntington (1905) and Smith (1974), is discredited on the basis of Neogene-dated volcanics that are located both on the top of the basin fill and within the Sistan depression (Jux and Kempf, 1983). However, Jux and Kempf (1983) did agree with Smith's deflation mechanism for the origin of the Sistan depression. Flat-lying Sistan beds and lack of visible faulting led Jux and Kempf to believe that tectonic activity played a minor role in the geomorphic history of the basin. They constructed the following climatic hypothesis to account for the origin of the depression: wind erosion occurred during cold, glacial episodes when water was held in storage by ice and snow in the upper drainage basin, and shallow lakes would flood Sistan during warmer interglacial episodes when snow and ice would melt in spring and summer. Within this climatic model, Jux and Kempf (1983) also proposed that three stream terraces along the lower Helmand River constituted evidence of the episodic lowering of the depression by deflation; each terrace was interpreted to represent an episode of lake stability in the depression.

Abundant eolian landforms and deposits in the basin (fig. 8) attest to strong eolian activity, both past and at present. However, wind erosion is localized and cannot occur in the hamuns and surrounding wetlands when they contain water.

In order to create the Sistan depression by deflation, the climate during most of the Quaternary must have been much drier than present hyperarid conditions. Considering the large size of the Helmand drainage basin with significant runoff from high mountains and known Quaternary fluctuations from adjacent areas such as the Caspian and Black Seas (Degens and Paluska, 1979; Paluska and Degens, 1979), it is highly unlikely the Sistan depression was dry during most of the Quaternary. Jux and Kempf cited Quaternary wind erosion in the 


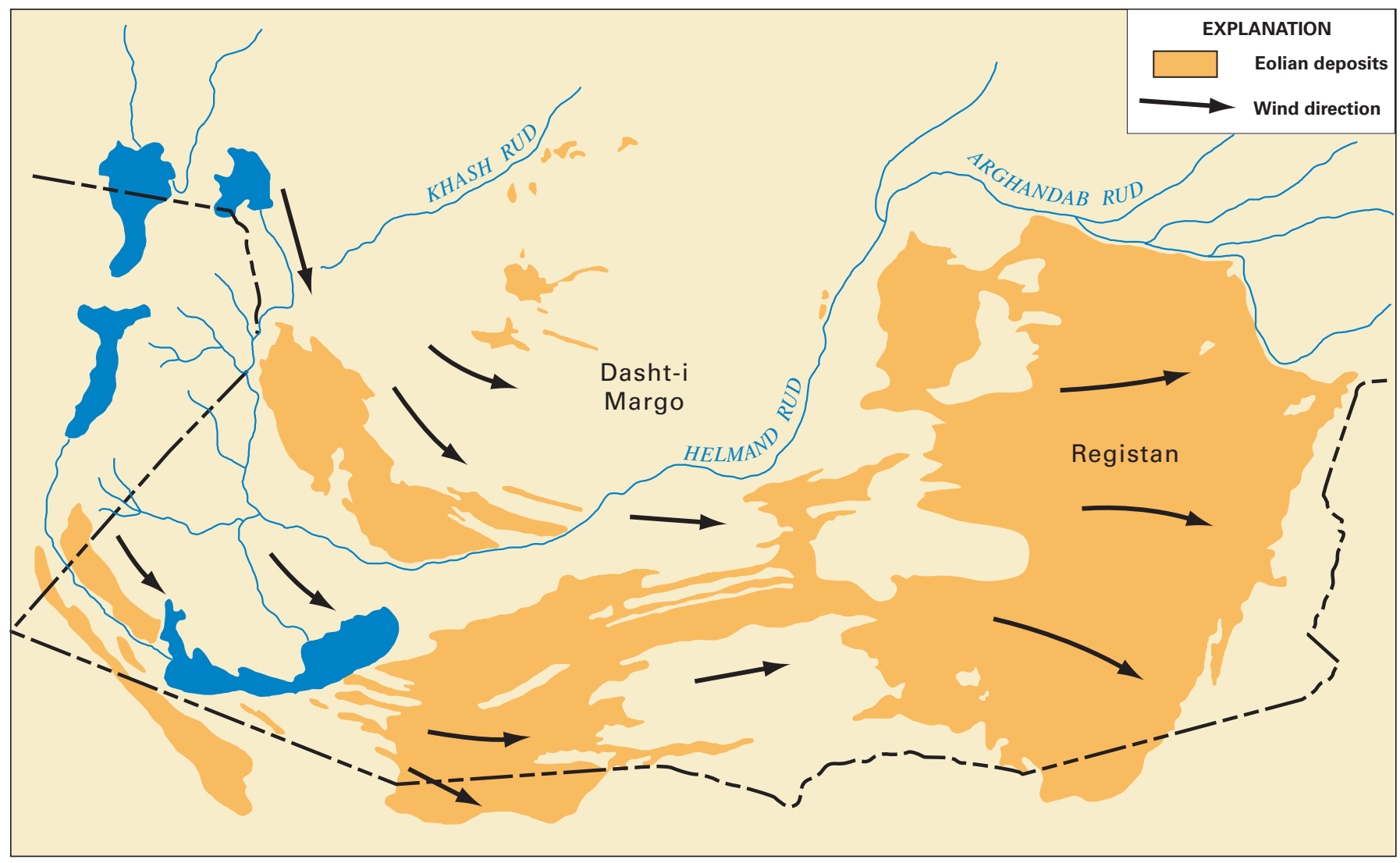

Figure 8. Eolian deposits and wind directions in the lower Helmand Basin.

Lut Basin as an analog to the Sistan depression; however, the Lut Basin is not fed by a major perennial flowing river.

There are several reasons why deflation alone is not the process that formed the Sistan depression. First, strong evidence for a tectonic origin of the depression has been discussed herein. The fact that recent tectonic activity is concentrated along the margins of the lower Helmand Basin, while the center contains flat-lying sedimentary beds, is not unique. Both the Tarim Basin in southwest China (Norin, 1941) and the Lut Basin in Iran (Conrad and Conrad, 1970a,b) exhibit the same geologic relationship. Furthermore, the hamun shapes are arcuate around the edge of the depression and coincide with the position of basin-controlling faults. Sar-o-Tar plain and the wind-scoured area to the south (known as Jehanum or Hell) are the only areas in the depression that are elongated parallel to the wind, and wind erosion is presently active in these areas. Second, if the Sistan depression was lowered during each Quaternary glacial episode, then there should be many more than three terraces in the Helmand Valley that would have recorded the sequential lowering of the base level. Third, nearly all fans, terraces, and basin surfaces are mantled by a layer of gravels that prevents significant deflation. Curiously, Jux and Kempf (1983) ignored the fact that the depression was chiefly formed during the late Tertiary; the middle terrace in Helmand Valley (35 meters above stream level) cannot be middle-late Quaternary in age if their proposed late
Miocene surface of the depression at Kuh-i Khwaja was only 55-60 meters above the present basin floor.

The question of climatic conditions during global episodes of glacial activity is the key to understanding the Quaternary history of the lower Helmand Basin. Was the basin occupied by pluvial lakes, as proposed by Huntington (1905) and Smith (1974), or was the Sistan depression dry, as suggested by Jux and Kempf (1983)? One factor overlooked by previous investigators is the lack of glacial deposits in the upper Helmand Basin. The north side of the Koh-i Baba Range, just west of Kabul, was glaciated several times during the Pleistocene (Grotzbach and Rathjens, 1969); however, no evidence of glaciation has been observed on the south side of the range, which drains into the Helmand Basin (Balland and Lang, 1974; Lang, 1975). The snowline on south-facing mountain slopes is as much as 400 meters higher than on north-facing slopes (Horvath, 1975), which illustrates the increased insolation received by south-facing slopes. However, increased insolation was not the sole reason for the absence of glacier buildup. The snowline during glacial episodes was as much as 1,000 meters lower (Grotzbach and Rathjens, 1969) than the present snowline. Lack of snow and ice accumulation during glacial episodes was due to a lack of moisture and must have been a major factor. Norin (1932) recognized a similar situation in the Tarim Basin; the north-draining Kunlun Mountains contained evidence of multiple glaciation, while no 
evidence of glaciation was found in the south-draining Tien Shan Mountains on the other side of the basin.

An apparent moisture decrease in the southern Hindu Kush Mountains during glacial episodes is also suggested by palynological studies in the Hindu Kush (Pias, 1974b, 1976) and by similar glacial-age precipitation decreases in Iran (Van Zeist and Bottema, 1977), in lake basins in the Near East (Bottema, 1978; Van Zeist and Bottema, 1982), and in the Rajasthan Desert (Singh and others, 1972, 1974). The correlation with Iranian and Near Eastern lake basins is especially strong because the Hindu Kush receives its moisture from the same source area and same winter depressions (cyclonic storms) that pass over these areas.

The primary reason that precipitation did not increase over these regions is a $5^{\circ}$ Celsius water-temperature drop in the Mediterranean Sea during times of worldwide glacial activity (Emiliani, 1955; Thunnell, 1979); hence, less moisture was picked up by eastward-moving storms. Also, fewer storms may have invaded southwest Asia because an expanded winter high pressure system existed over the Eurasian continent during glacial times; this high pressure cell may have deflected storms to the south (Lamb, 1977).

The combination of a somewhat reduced glacial-age precipitation and lower evaporation rates probably had a counterbalancing effect that may account for the fact that nearly all the closed basins in Iran did not experience major geomorphic changes during the late Quaternary (Bobek, 1963; Krinsley, 1970, 1972). However, another important climatic factor to be considered in the Helmand and Lut Basins is wind activity.

The great volume of dunes in the lower Helmand Basin may be evidence of enhanced wind erosion during times of reduced, glacial-age precipitation. The dunes in the large Registan sand sea (fig. 8) were found to be stabilized and oxidized; therefore, they provide evidence of a past episode, or episodes, of accelerated eolian sand movement and deposition in the basin. Although the dunes were not directly dated, 4,000-year-old pottery was found in 1976 on the surface of dunes located at the eastern edge of the dunefield by members of a Smithsonian archeological team, which indicates that the dunes have been stable for at least the late Holocene. Stabilized sand seas in other subtropical deserts were active during the last glacial episode (Bowler, 1978; Whitney and others, 1983), including the dunefields in the nearby Thar and Rajasthan deserts (Allchin and others, 1978; Singh and others, 1972, 1974). Thus, until the dunes can be dated directly by luminescence methods, it is reasonable to suggest that the stabilized dunes in the Registan were also last active during the last Pleistocene glacial episode.

Increased windiness in the Helmand Basin was not a consequence of low precipitation but probably was caused by the presence of cold, high-pressure air over Soviet Central Asia. The gradient between high-pressure arctic air and the low-pressure summer thermal cell over the lower Helmand Basin was likely greater during glacial episodes than at present and resulted in winds of greater velocity and frequency. Thus, wind erosion has undoubtedly enhanced the formation of the
Sistan depression; however, this contribution is considered to be minor relative to late Tertiary and Quaternary tectonic subsidence of the depression.

Two former shorelines at altitudes of about 3 meters and 10 meters above the Iranian hamuns were found and interpreted by Huntington (1905) to represent temporary stillstands during the progressive desiccation of the last Pleistocene high lake stand. Because the Neogene age of the Sistan beds negates this interpretation, these shorelines must represent either expansion of the late Quaternary hamuns into larger lakes or, possibly, evidence of Quaternary subsidence of the lake floor. Radiocarbon dating of calcium carbonate-rich lacustrine sediments in Afghan Sistan and along the Khash Rud by Pias (1972, 1974a,b, 1976) indicates that Quaternary lake expansions did take place in the Sistan depression during global interglacial climates. Pias obtained an age of $9,030 \pm 125$ years before present on a lake deposit exposed by wind erosion in the floodable land tract east of Zaranj. He also obtained ages of 30,300 $\pm 1,050$ years before present and 33,200 $\pm 1,600$ years before present on calcareous sediments that he collected on small mounds located at the mouth of, and many kilometers upstream in, the Khash Rud valley. Unfortunately, Pias did not give stratigraphic descriptions of these samples, their altitudes, or their exact localities. It is also not clear whether Pias dated soil carbonate or carbonate precipitated in lake sediments. Thus, it is impossible to ascertain whether these dates represent lake expansions that were responsible for the two low shorelines. Smith (1974) and Jux and Kempf (1983) rejected the radiocarbon dates; however, the dates do correlate with well-known episodes of increased moisture in the subtropical deserts of Australia (Bowler, 1978), North Africa (Williams and Faure, 1980; Street and Grove, 1976), Arabia (Whitney, 1983; Whitney and others, 1983), and Pakistan and India (Allchin and others, 1978; Singh and others, 1972). Although the geologic data from the Sistan depression is at best circumstantial, a tentative correlation with pluvial deposits of similar ages in deserts located both to the east and west of the Helmand Basin suggests that Quaternary lake expansion in Sistan was probably synchronous with interstadial (interglacial) climates. If this correlation is correct, then the Holocene climate in Sistan, beginning approximately 10,000 years before present, was relatively wet in comparison to the last glacial episode (approximately 18,000 years before present). The lowest shoreline around the depression may then represent an early to middle Holocene expansion of the hamuns. Future radiometric, cosmogenic, and (or) luminescence dating will eventually refine or revise the lake history in Sistan.

The Caspian, Black, and Aral Seas all expanded and filled to their highest shorelines during the time of maximum ice expansion (Ehlers, 1971), although active Quaternary subsidence in these basins makes it difficult to estimate how much larger the seas were (Paluska and Degens, 1979). These inland seas were models for Huntington's (1905) lake history for Sistan. However, these lakes greatly increased in size because they were fed by glacial meltwater; Sistan and 
other Iranian playas were not. Sources of moisture for the expanded pluvial lakes of Central Asia were not the same for the stable-to-drier lakes of Southwest Asia. Precipitation in the southern Hindu Kush and Iranian highlands was insufficient to form large accumulations of ice or to increase runoff within the lower Helmand Basin. Low precipitation was characteristic over most of the Soviet Union during the glacial maximum. Velichko (1984) has estimated that precipitation was 25-50 percent of present totals and that active loess deposition took place during the glacial maximum.

In Afghanistan, Pias (1974a) stated that arboreal pollen was reduced to less than 5 percent during the last glacial maximum, and the nonarboreal pollen was predominantly steppe vegetation characterized by Artemisia and chenopod-

dominated, marshy, saline flood plains. This vegetation association is similar to the present vegetation in the mountains of Afghanistan.

When the large continental ice sheets disappeared 18,000-13,000 years ago, subtropical deserts began to receive increased precipitation. The melted continental ice filled the oceans to near present sea level during early-middle Holocene. By mid-Holocene, sea level was actually a meter or so higher than at present (Fairbridge, 1961; Woodruff and Horton, 2005), which expanded the water surface area available for winds to pick up moisture. Sea surface temperatures rose to levels $1^{\circ}-2^{\circ}$ Celsius greater than they were in the late 20th century (Emiliani, 1955; Thunnell, 1979), which in turn increased the amount of moisture evaporating into the air in the warm tropics and subtropics. This increased Holocene moisture is reflected in the vegetation changes that are recorded in pollen profiles in western Iran (Van Zeist and Bottema, 1977), the Thar and Rajasthan Deserts (Allchin and others, 1978; Allchin and Goudie, 1978; Goudie and others, 1973), the Sahara (Williams and Faure, 1980), and Saudi Arabia (Schulz and Whitney, 1986). Precipitation steadily increased over these regions from the beginning of the Holocene to between 6,000 and 5,000 years before present. In Iran, precipitation levels since that time have not significantly declined; however, aridity did increase in the Rajasthan about 3,000 years ago. This difference is undoubtedly due to two different moisture sources: moisture in the Rajasthan comes from the monsoon; whereas, Iran and the Helmand Basin are supplied by Mediterranean moisture.

The mid-Holocene return of forests to the Zagros Mountains (Van Zeist and Bottema, 1977) roughly correlates in time with the expansion of Mesopotamian civilizations along the Tigris-Euphrates. The transition from the Neolithic to the protourban settlements of the Ubaid, and later Sumer, cultures in Mesopotamia occurred between 7,000 and 6,000 years ago when climatic conditions in the Near East were "optimal" (Butzer, 1978). Relatively wetter conditions in Sistan during the mid-Holocene may have played been instrumental in the construction of early settlements such as Shahr-i Sokhta (Tosi, 1973, 1976); however, no geologic data presently exist to prove climatic conditions and water supply about 6,000 years ago were significantly different from the present (Costantini and Tosi, 1978). Enzel and others (1999) found that middle Holocene lakes in the Thar Desert dried up about $4,800{ }^{14} \mathrm{C}$ years before present, about 1,500 years before the Harrapan civilization flourished. Thus, a wetter climate did not coincide with the growing and expanding civilization in the Indus Valley.

\section{The Modern Desert Environment}

\section{Climate}

The harsh extremes of temperature, winds, and even precipitation leave an indelible impression upon the visitor to Sistan. Sir Frederic Goldsmid (1876) referred to the Helmand delta region as being the "most odious" place on the face of the Earth. Many instances of the effects of extreme temperatures and fierce windstorms on man and beast are recorded in the reports of the various Sistan boundary commissions. For instance, McMahon (1906) recounted one 4-day blizzard in 1905 that resulted in the death of more than 200 camels. In 1975 , our own expedition was forced to close its field season early because of a sudden and unusually forceful gale that destroyed three tents before we were able to take them down. From 1998 until early in 2005, the Helmand Basin experienced the longest drought in 175 years of historical record.

The climate of the Helmand Basin is hyperarid except at the edges of the basin, where it is arid. According to UNESCO (1979) definitions, arid and hyperarid zones are distinguished

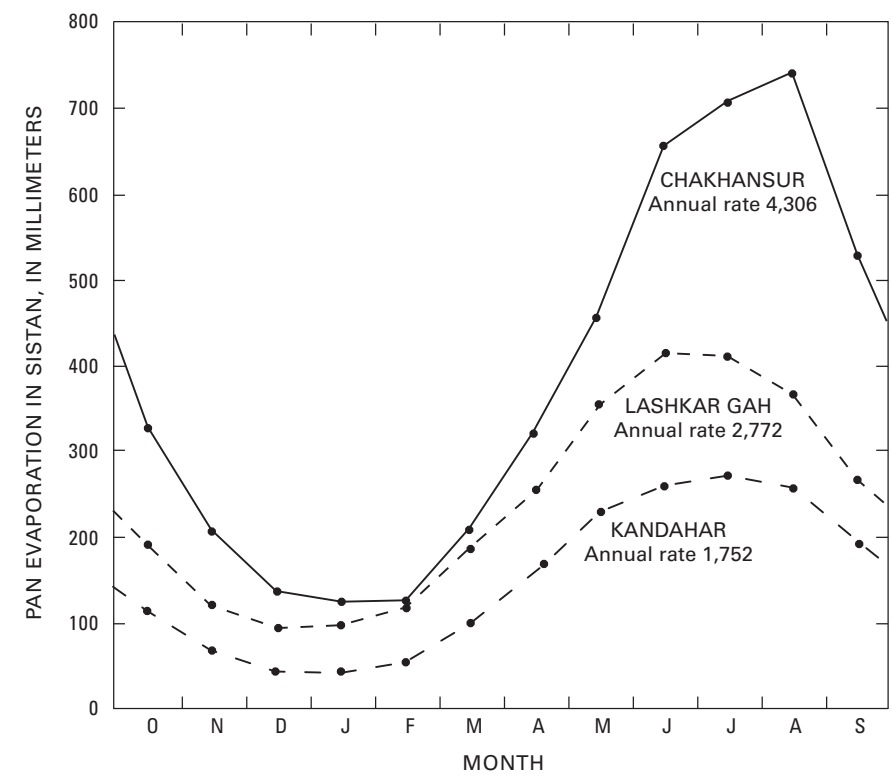

Figure 9. Monthly and annual pan evaporation rates for the lower Helmand Basin. Data from Brigham (1964). 
by the ratio of mean annual precipitation $(\mathrm{P})$ to mean annual potential evapotranspiration (ETp). Arid zones are defined by P/ETp of less than 0.20 and greater than 0.03 , and hyperarid zones have less than $0.03 \mathrm{P} / \mathrm{ETp}$. At the meteorological stations that have published annual totals of potential evaporation (fig. 9), the P/ETp is 0.027 at Lashkar Gah, 0.016 at Chakhansur, and 0.08 at Kandahar.

Climate diagrams (Walter, 1973) were constructed from the meteorological data available for the basin and adjacent areas (fig. 10). These diagrams illustrate the relative periods of wetness and drought during the year by plotting temperature and precipitation on the same graph for each month. Periods of effective moisture exist when monthly precipitation (in millimeters) is greater than twice the air temperature in degrees Celsius. The climate diagram for Herat shows the standard units of $10^{\circ}$ Celsius increments for temperature on the left side of the diagram and 20-millimeter increments of precipitation on the right side. The stations in the lower Helmand Basin and farther south in Pakistani Baluchistan clearly show that drought conditions (shown in orange color) dominate almost year round; very small amounts of effective moisture (blue color) are available during January and February, a time when it is too cold for agriculture. Outside the hyperarid zone, at Herat and Kandahar, the relatively humid season lasts from November to April.

The lower Helmand Basin is situated between $29^{\circ}$ and $32^{\circ}$ north latitude on the north edge of the subtropical dry zone, a belt of aridity that extends from northwest Africa (the Saharan-Arabian Deserts) eastward to the Thar-Rajasthan Deserts of Pakistan and India. This arid climatic zone is the result of worldwide circulation patterns of air that create semipermanent cells of high pressure (Hadley cells) in the general region of the tropics. Cold, dry, polar air descends from high altitudes and is subjected to compressional heating at the adiabatic rate of $10^{\circ}$ Celsius per 1,000 meters. Because it is hot and dry, the air is incapable of producing clouds or rain when it reaches the Earth's surface. The low percentage and frequency of cloud cover together with the clarity of dry air allow a great deal of solar radiant energy to reach the ground, which results in very high ground temperatures. The heated ground returns much of this heat to the atmosphere in the form of long waves of radiant energy. High daytime air temperatures that are characteristic of most deserts are primarily due to heating of the lower atmosphere by terrestrial radiation.

Summer temperature maximums of greater than $50^{\circ}$ Celsius ( $122^{\circ}$ Fahrenheit) have been recorded in the delta region of Sistan (Afghan Institut de Meteorologie, 1971; U.S. Agency for International Development, 1976). Temperature maximums decrease outside the delta region because the land surface steadily rises in altitude toward the mountains that rim the basin. At Zaranj, the provincial capital of Nimruz Province in Sistan, the midsummer daily air temperature range is nearly $20^{\circ}$ Celsius. A daily range as great as $32^{\circ}$ Celsius and a monthly range of $43^{\circ}$ Celsius has been reported by the Afghan Institut de Meteorologie (1971). These high diurnal temperature ranges occur because terrestrial radiation continues after the sun sets, which causes ground and air temperatures to drop rapidly on cloudless evenings.

Winter temperatures in the lower Helmand Basin are somewhat colder than in most subtropical deserts. Freezing temperatures can occur from November to March; thus, the growing season averages only about 270 days a year, which is generally too short and cold for tropical and subtropical vegetation. During the mid-1970s I saw only two small date palms in the Helmand Valley; however, only $100 \mathrm{~km}$ to the south in Baluchistan these palms are common near springs and irrigation canals. Sleet and snow accompany these low temperatures on occasion because winter is the main precipitation season. According to residents in the basin, snow rarely lasts the day and apparently falls only once every 2 or 3 years. Published data on yearly snowfall are not available.

Because of the relatively cold winters, the mean annual temperature range in the lower Helmand Basin is $27^{\circ}$ Celsius, whereas the range in most Middle Eastern deserts is from $15^{\circ}$ to $20^{\circ}$ Celsius (Beaumont and others, 1976). High annual temperature ranges are also common to the north in the deserts of Iran and in the former Union of Soviet Socialist Republics. In this respect, the climate of the lower Helmand Basin more closely resembles that of the Asian continental deserts than the subtropical deserts of the Middle East and Africa.

The lower Helmand Basin exhibits two other characteristics of continental deserts: the basin is situated a great distance from its moisture sources, and it is rimmed by mountains that prevent the invasion of many moist air masses. For example, the East Iranian and Makran Ranges in Baluchistan prevent the northward penetration of the summer monsoon.

The position of air masses over Asia in winter appears to be related to the sudden shift of the westerly subtropical jet stream from the north side of the Himalaya Mountains to the south side (Beaumont and others, 1976). Summer conditions, on the other hand, occur when the subtropical jet stream shifts back to the north. Fall and spring are relatively short transitions between the winter and summer conditions. Summer climatic conditions last from April to October, and winter conditions last from November to April.

Accompanying the winter shift of the subtropical jet stream is the southward shift of the polar front, that is, the boundary between polar and tropical air masses. Wave disturbances are commonly generated along this front over the North Atlantic Ocean and the Mediterranean Sea. These frontal disturbances, or cyclones, travel along eastward tracks from the eastern Mediterranean area and penetrate much of western Asia and the Middle East, regions that are dominated by dry descending air in summer (Beaumont and others, 1976; Ganji, 1968; Lydolph, 1977). This winter regime of Mediterranean-type precipitation is responsible for virtually all the moisture that falls in the Helmand Basin.

Precipitation reaching Sistan must travel at least 2,600 kilometers from the eastern Mediterranean area and cross several areas of higher relief that deplete the cyclones of most of their moisture. Precipitation totals from Mediterranean storms are greatest over the high Zagros ranges in western 


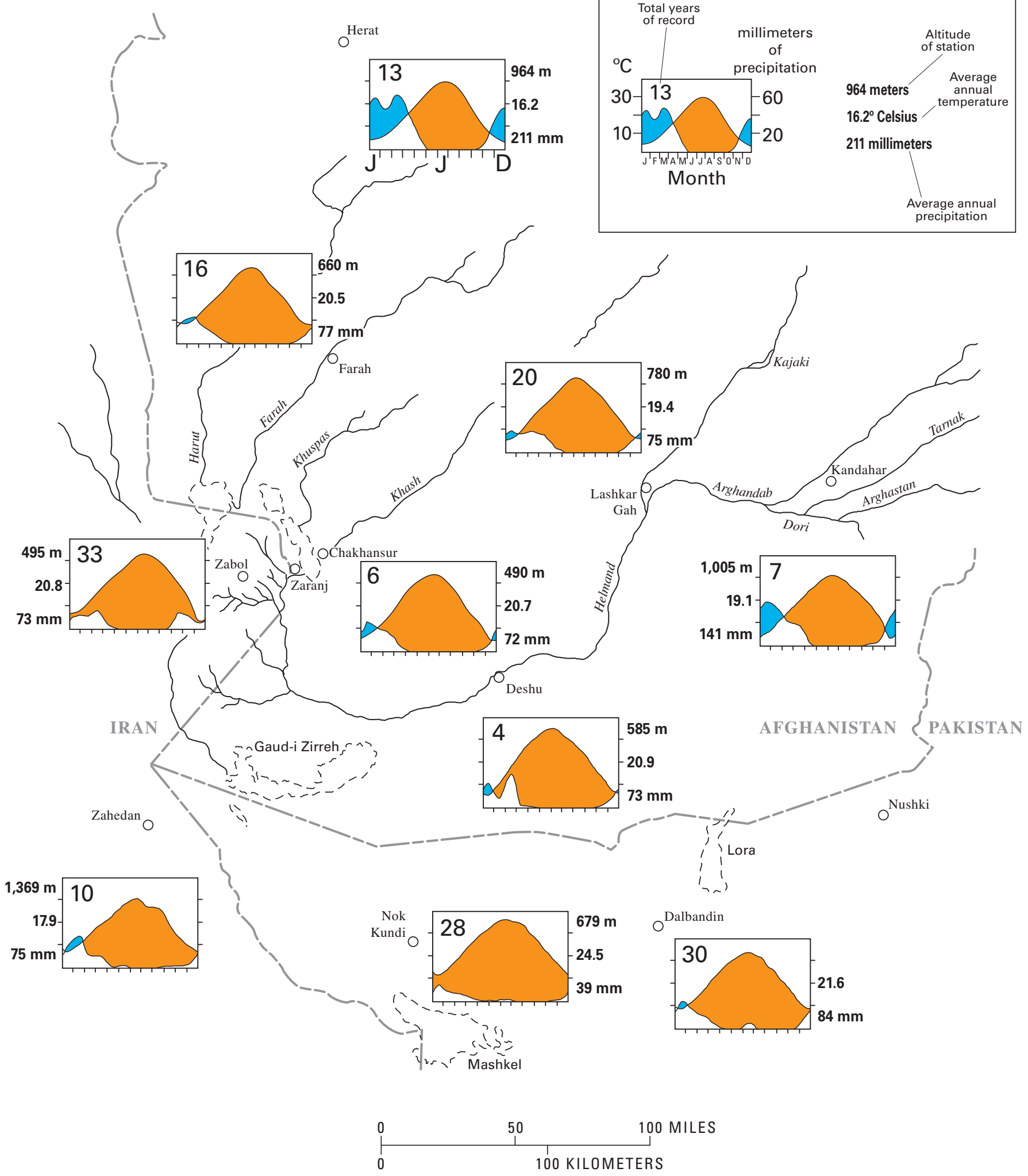

Figure 10. Climate diagrams for the Helmand Basin and adjacent areas. 
Iran and lowest over the interior desert basins of eastern Iran (Ganji, 1968). Annual precipitation averages about 75 millimeters per year over most of the lower Helmand Basin (fig. 10). Precipitation in the mountains north of Herat and in the eastern Helmand Basin at Kandahar averages about two to three times that received on the desert plains and on the delta. The driest and warmest region is not on the Helmand delta, but farther south in Baluchistan at the village of Nok Kundi, Pakistan. The annual temperature at Nok Kundi is almost $4^{\circ}$ Celsius warmer than at Zabol (Iran) or Chakhansur, Afghanistan, and the annual rainfall is only 39 millimeters. The main reason the temperature is warmer in Baluchistan than in the lower Sistan depression is that Sistan is subject to stronger summer winds than Nok Kundi. The very low precipitation at Nok Kundi is due to a rain shadow effect; mountains surround the village on three sides. Both meteorological stations at Dalbandin and Nok Kundi record a slight amount of summer precipitation, which is evidence of the northernmost invasion of monsoon moisture in Baluchistan. Residents in Baluchistan speak of the destructive flash floods that accompany the rare invasions of monsoon storms from the Indian Ocean. Nok Kundi received 16.5 millimeters of precipitation in 24 hours during one July storm (Takahashi and Arakawa, 1981). The Chagai, Koh-i Sultan, Saindak, and Kacha Mountains, however, serve as a barrier to monsoon precipitation in the Helmand Basin.

Another continental aspect of Sistan's winter weather is the frequency with which the region is subjected to waves of cold, polar air (Asiatic High) from the interior of Central Asia. Winter insolation effects are weak and tend to be dominated by these invasions of cold air. It is common for the air temperature to drop several degrees after the passage of a rain-bearing cyclone because the cyclonic low pressure (depression) tends to pull in the dry, cold, northern air.

\section{Desert Winds and Eolian Environment}

Winds are the most notable and frequently described feature of the lower Helmand Basin, especially in Sistan. Violent sandstorms may occur at any time of the year; however, winds blow with a great regularity from May to September. This summer wind blows steadily from the northwest and is locally called the bad-i-sad-o-bist ruz, or "Wind of 120 Days." This wind has a significant effect on the landscape and the lives of the basin's inhabitants: eolian erosional and depositional landforms dominate much of the desert basin outside the Helmand Valley, and drifting sand has been a principal natural determinant in changing irrigation patterns and the location of agricultural endeavors throughout historical times.

The position of the summer low-pressure (monsoon) system over the mountains in Pakistan is the principal reason that high-pressure air (the Azores High) is drawn in to Sistan from the Caspian Sea region (Ganji, 1968; Kendrew, 1961). Sivall's (1977) compilation of pressure data in Afghanistan, however, shows that a significant heat low develops over the Dasht-i Margo independent of the heat low centered over western
Pakistan near the town of Sibi, on the Indus plain. The position of this heat low over the basin explains the pattern and direction of dunes in the basin; wind streamlines, as observed on Landsat images of southwestern Afghanistan, curve in a counterclockwise motion from the Sar-o-Tar area to the Registan (fig. 8). Low, isolated mountains along the southern edge of the basin cannot alone account for such a massive wind deflection. Thus, wind directions are a direct consequence of the Dasht-i Margo thermal low. In a strict sense, the "Wind of 120 Days" is a trade wind that is accelerated and deflected by a local heat low before the dry, originally polar air can reach the Intertropical Convergence Zone, which is located over the north-south-striking Sulaiman Mountains of Pakistan.

The Sulaiman Mountains and the mountains along the Makran coast also serve as a southern barrier to the moisture-bearing monsoons. Occasionally, monsoons do invade the high mountainous areas of eastern Afghanistan and cause summer floods (Sivall, 1977). Some of this precipitation may enter Sistan from eastern tributaries of the Helmand River.

The "Wind of 120 Days" is stronger in Sistan than over the rest of the Helmand Basin. Mean monthly wind velocities are given for Lashkar Gah and Zaranj in figure 11. A striking increase in wind velocity occurs from May to September at Zaranj but not at Lashkar Gah, which is located about 200 kilometers to the east. Stronger winds are concentrated along the west edge of the basin because the wind accelerates along a long, narrow corridor between the mountains of Iran and Afghanistan. The "Wind of 120 Days" is felt farther south in Baluchistan; however, the intensity is not as great. The maximum, mean monthly wind speed at Nok Kundi, Pakistan, is 4 meters per second (Takahashi and Arakawa, 1981) and is about 6 meters per second at Zaranj (Brigham, 1964). Comparison of these two stations is tenuous, however, because data probably were collected by different methods and over different time periods.

According to members of the Sistan Arbitration Commission, who lived in Sistan from 1903 to 1905, the "Wind of 120 Days" blows almost constantly day and night during the hottest months of the year. Sustained, hurricane-force winds of 29-36 meters per second (65-80 miles per hour) were experienced frequently. One storm in 1905 recorded an average velocity of 39.3 meters per second ( 88 miles per hour) for a 16-hour period. During that storm, a maximum velocity of 53.6 meters per second (120 miles per hour) was recorded (McMahon, 1906). The pebbles, sand, dust, and debris carried by the wind, plus its continual noise, make living conditions particularly undesirable during the summer. Violent windstorms are by no means limited to one season and were a subject of considerable interest to most early foreign visitors to this area (for example, Tate, 1910-12).

The approach of a windstorm is the same in summer as in winter. The days preceding the arrival of the storm become slightly, but detectably, warmer and the air becomes still, or a slight breeze may blow from the southeast. Less than a day before the gale arrives, small cirrus clouds usually appear in the northwest. Strong winds may arrive suddenly, in the space 


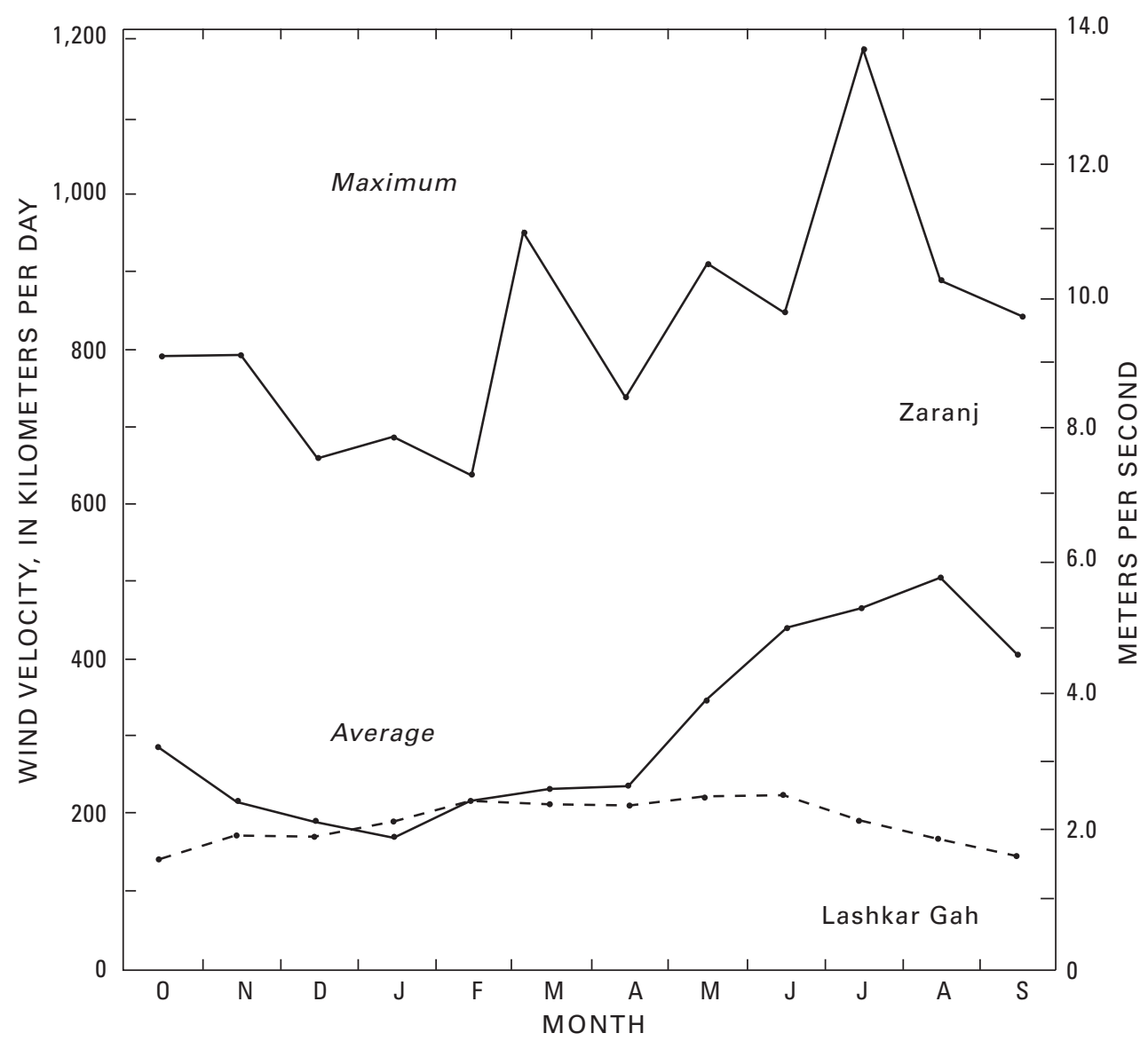

Figure 11. Mean monthly wind velocities for Zaranj and Lashkar Gah. Maximum monthly wind velocities are shown for Zaranj.

of only a few minutes, or the winds may build strength over half a day. A marked rise in temperature accompanies the wind; however, when the strong winds abate, normally after several days, the air temperature is noticeably cooler. After an interval of time, calm days begin to become more frequent and the temperature begins to rise again, seemingly initiating the next windstorm cycle.

In the summer, daily winds blow about 9-11 meters per second (20-25 miles per hour), with gusts up to 18-22 meters per second (40-50 miles per hour) (U.S. Agency for International Development, 1976). Evidence that these strong winds existed in historical times is attested to by dated deposits of eolian sand and by the standing remains of windmills that are found both in and outside the delta region. The most commonly found windmills were built in the 14th-15th centuries and were used to grind grain (Whitney and Trousdale, 1982, 1984).

The presence of exceptionally strong winds for long durations has a marked effect on the potential evaporation rates in the Helmand delta region (fig. 9). Because the "Wind of 120 Days" is strongest in Sistan, where Chakhansur village is located, evaporation totals are higher there than elsewhere in the Helmand Basin, as is shown by lower totals at Lashkar Gah and Kandahar (Brigham, 1964). Measurements at Chakhansur that exceed 4,000 millimeters per year were recorded by the Afghan Institut de Meteorologie (1971). This potential evaporation rate is 2.5 times greater than rates in the eastern part of the basin and is among the highest rates recorded around the globe.

\section{8-2005 Drought}

The Helmand Basin has recently experienced an unusually long 5-year drought from 2000 through early 2005 (United Nations Environment Programme, 2003, 2006). Combined with war and severe political disruption over the past 2 decades, the 5-year drought has created conditions of widespread famine that affected as many as 6 million people in central and southern Afghanistan. A suggested climatic forcing mechanism has been proposed for the recent drought by Barlow and others (2002). A prolonged ENSO (El NiñoSouthern oscillation) cold phase (known as La Niña) from 1998 to 2001 and unusually warm ocean waters in the western Pacific appear to have contributed to the prolonged drought. The unusually warm waters (warm pool) resulted in positive precipitation anomalies in the Indian Ocean and negative anomalies over central Afghanistan (Barlow and others, 2002).

The hamuns, nearly 4,000 square kilometers in extent, in both Iranian and Afghan Sistan went completely dry in 


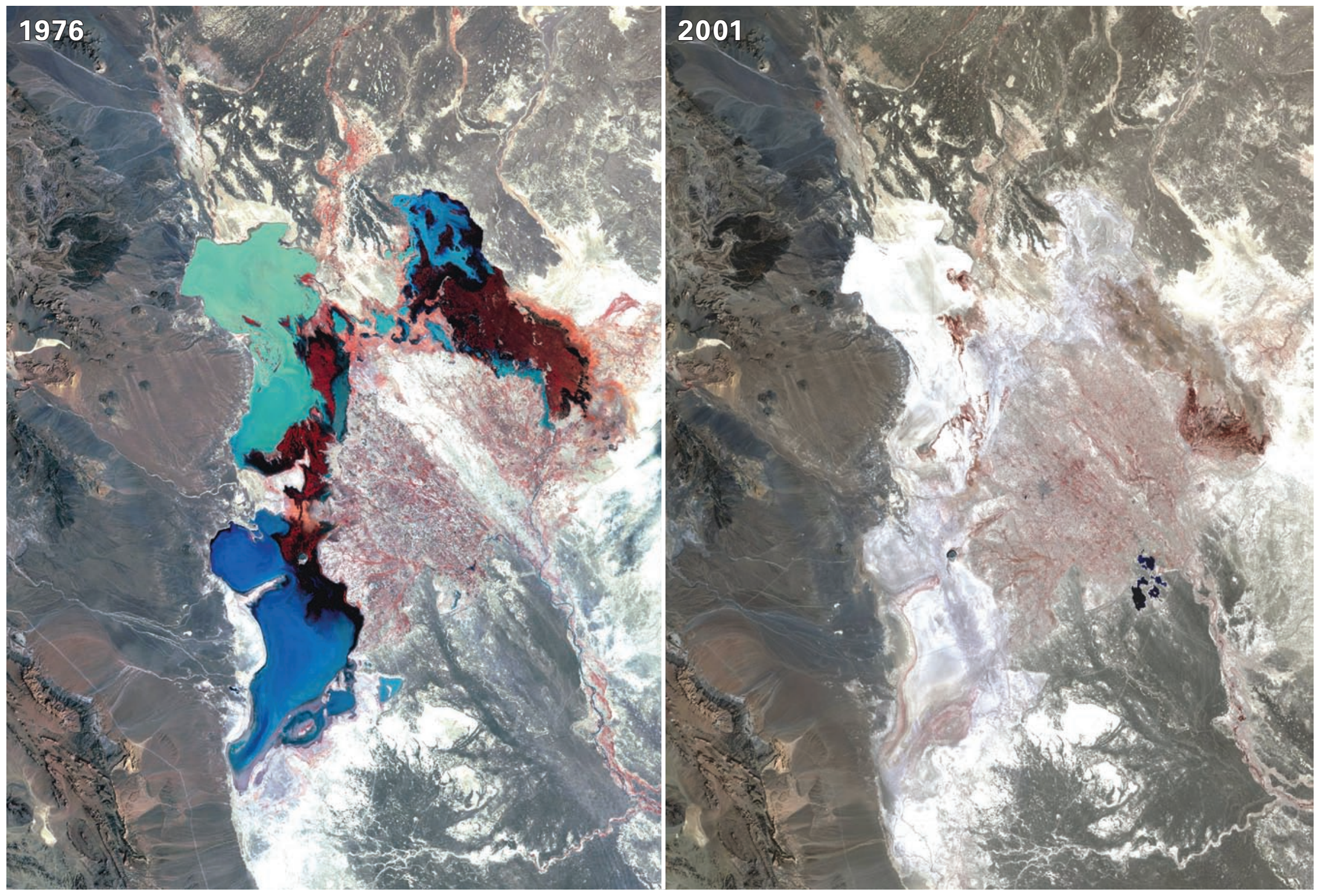

Figure 12. Landsat images of the Sistan delta and hamuns in 1976 and 2001. 1976 was a relatively wet year and 2001 was a drought year and the hamuns were almost completely dry. 
2001-2002: a human and natural catastrophe. A contrast between a relatively wet year in 1976 and the nearly dry hamuns in 2001 in shown in figure 12. Millions of fish and untold numbers of wildlife and cattle died. Agricultural fields and approximately 100 villages were abandoned, and many succumbed to blowing sand and moving dunes (Partow, 2003). Although one flood occurred in April 2003, about one-half of the 1997 population had left Sistan by November of that year. Finally, in March 2005, melting snow in combination with strong spring rains flooded the Helmand Valley and delta and partially refilled the hamuns. In 2006, the United Nations Environment Programme released a study of environmental change in Sistan from 1976 to 2005 that documents hydrologic and vegetation changes on the delta based on satellite image analysis.

Sistan is one of the windiest deserts in the world. Except in the immediate areas of active fluvial and lacustrine deposition, the landscape in the lower Helmand Basin is dominated by eolian erosional and depositional landforms. In the Sistan depression, active wind erosion and(or) sand movement occurs wherever vegetation is not supported by irrigation or ground water. The topography in Sistan has been and continues to be dominated by the interplay of eolian and fluvial processes in the depression. Wind-eroded yardangs (McCauley and others, 1977) and dunefields are common features in the lower Helmand Basin. Active dunes presently cover most of the agricultural fields that supported multiple historical societies over the past 3,000 years (Whitney and Trousdale, 1982, 1984). Sistan inhabitants adapted to these winds during historical times: nearly all structures were constructed with their long walls parallel to the north-northwest wind direction, and during medieval times uniaxle windmills were constructed for grinding grain. In modern Iranian Sistan, small wind intakes (bad geres) are built on the top of village houses as a form of air conditioning during the summer.

MODIS satellite images of Sistan taken during the recent drought capture striking evidence of strong eolian erosion and dust generation in the depression (fig. 13). Dust from the area of dry hamuns and delta can be traced on satellite images moving across Pakistan and over the Arabian Sea. When the

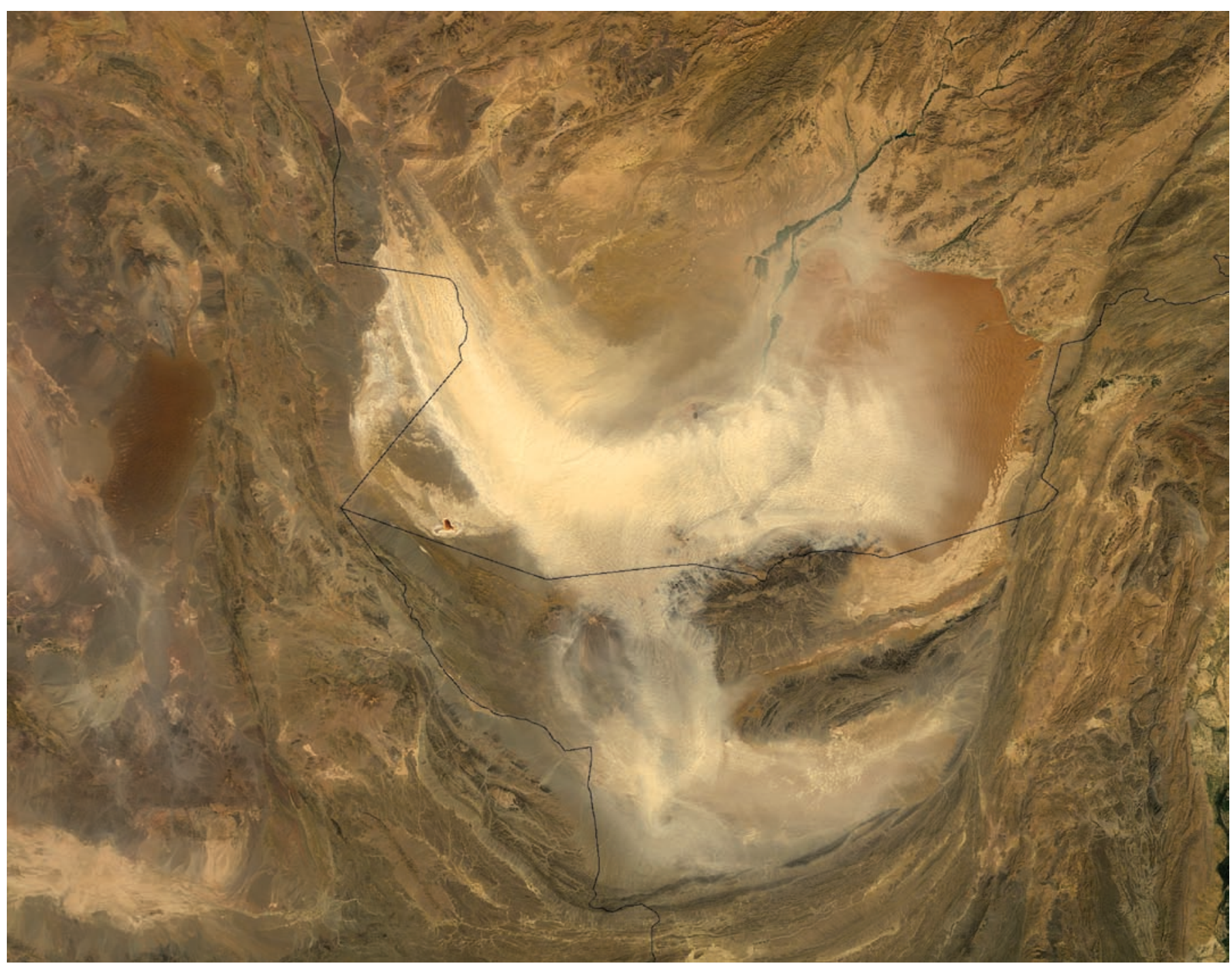

Figure 13. MODIS image (weather satellite) of dust deflation from the dry hamuns in Sistan on September 13, 2003. 
hamuns are dry, Sistan becomes a major contributor of global aerosols. Middleton (1986) discovered that over 30 dust storms per year originate in Sistan, more than from any other area in south or southwest Asia.

\section{Hydrology of the Helmand River System}

\section{Drainage Features and Discharge}

The Helmand River drains the southern one-half of Afghanistan and supplies about 80 percent of the waters that empty into the Sistan depression. The headwaters of the Helmand River originate about 90 kilometers west of Kabul on the southern flank of the Koh-i Baba and on the western slopes of the Paghman Ranges, where individual mountains reach altitudes of 4,400 meters. The profile of the river is illustrated in figure 14, and the mean annual downstream discharges of the Helmand are superimposed on the stream profile (Brigham, 1964; U.S. Agency for International Development, 1976). The river steadily increases its volume from the steep headwaters to its junction with the Arghandab River, the
Helmand's largest tributary. Downstream from the junction, the volume of streamflow steadily diminishes because of irrigation diversions, evapotranspiration losses, and ground-water seepage. The Helmand flows nearly 500 kilometers beyond its junction with the Arghandab through a desert with little to no local runoff. Previous investigators have stated that groundwater seepage was the major reason for decreasing annual downstream discharges (Radermacher, 1974, 1976; Jux and Kempf, 1983); however, water diversions for domestic use and agriculture are the main siphons of water from the river. There are more than 750 kilometers of irrigation canals maintained by the Government of Afghanistan in the Helmand Basin, and this figure does not include local village canals downstream from Darweshan (U.S. Agency for International Development, 1976). About 78 kilometers downstream from Chahar Burjak (figs. 2, 14), 45-55 percent of the Helmand's discharge is diverted into Iranian Sistan at the Band-i Sistan. The balance of the discharge flows toward Zaranj in what was once called the Nad-i Ali channel, and at Zaranj, the Helmand flows into the Shelah Charkh channel, which empties eventually into the Hamun-i Puzak.

The river is 1,100 kilometers long if one considers the Hamun-i Puzak to be the terminus; but in years of exceptionally high flows, the Helmand waters spill from the Hamun-i

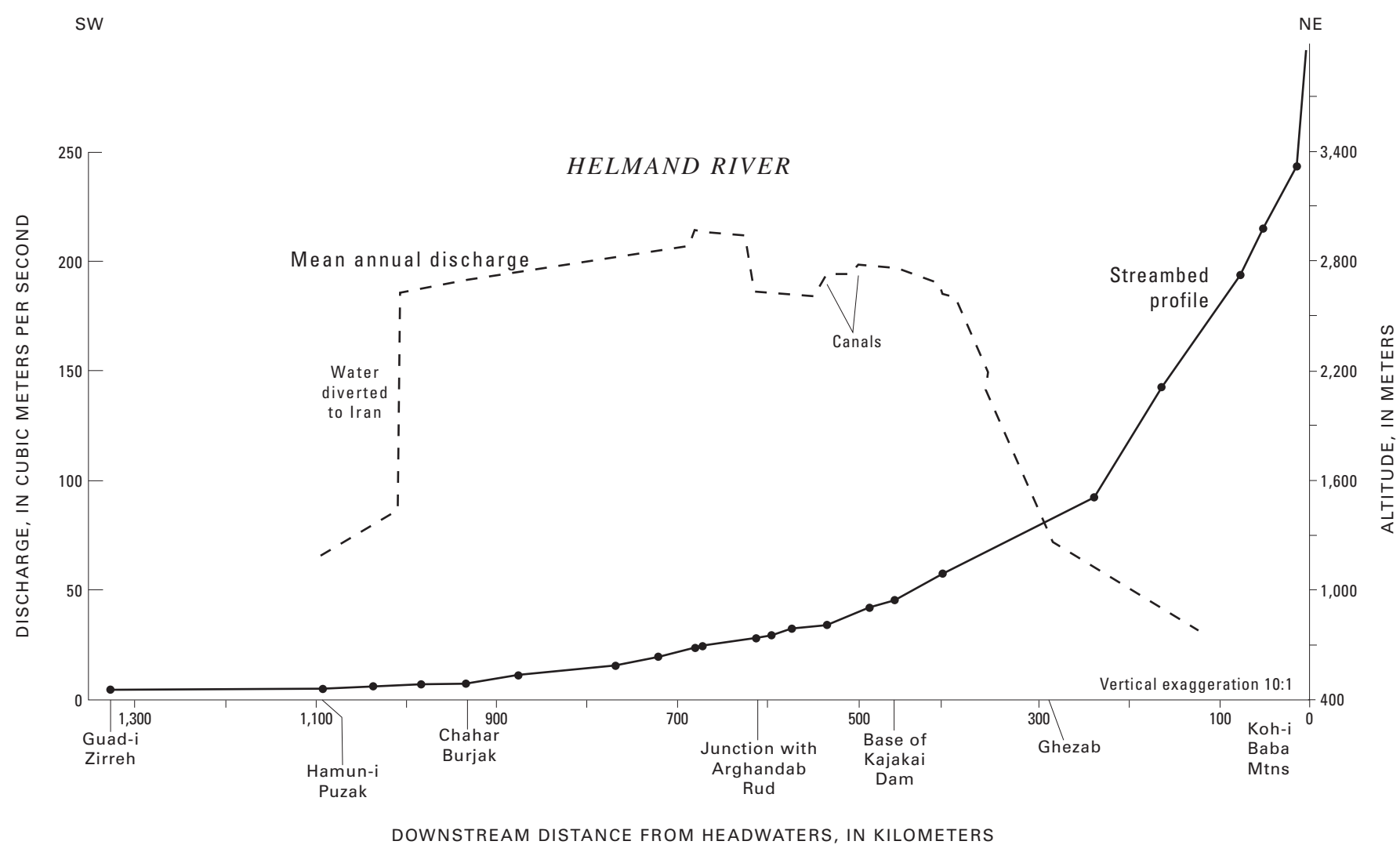

Figure 14. Stream profile of the Helmand River with mean annual discharges shown along the profile. 
Puzak into the Hamun-i Sabari, which in turn merges with the Hamun-i Helmand in Iran and subsequently overflows to the south into the Gaud-i Zirreh, the lowest, and normally dry, hamun basin. When the Helmand floodwaters reach the Gaud-i Zirreh, the river has increased its length another $200 \mathrm{~km}$ (fig. 14). Local residents in Sistan stated that the hamuns overflow into the Gaud-i Zirreh once every 20-25 years. After the flood of 1885, the largest flood on record, the Gaud-i Zirreh did not dry up until 1898 (Ward, 1906).

The extent and volume of the hamuns varies substantially from season to season and from year to year. The hamuns expand during the spring and reach a maximum size in late May or June and then steadily shrink to a minimum size in the late fall because of the high evaporation rates and low summer inflow. In years of low discharge, the hamuns can dry up for as long as 3-4 months. This happened in 1902 (Ward, 1906) and, on the basis of a conversation with Ghulam Khan (the oldest villager interviewed in 1975), it appears that the hamuns went dry twice from 1905 to 1946, a time period for which no hydrologic records or documented observations exist. Construction of the Kajakai Dam in 1952 on the upper Helmand River has reduced the frequency of the river failing in its lower reaches, except during extremely dry years. During the 1998-2005 drought, however, the hamuns were dry or nearly dry on several occasions.

Snowmelt and spring precipitation in the mountainous, upper regions of the basin are the main sources of runoff. Maximum, median, and minimum discharges for the Helmand and Arghandab Rivers for 1948-60 are shown in figure 15 (Brigham, 1964). These discharges are releases from the Kajakai and Arghandab Reservoirs, which have introduced a slight lag effect into the data, especially during early spring when the reservoirs are filling and during periods of low flow when some storage water is released. Stream discharges are highest in the months of March through May, during the spring thaw in the mountains; in fact, one-half of the annual runoff occurs during April and May. After May, stream discharges commonly fall by a factor of five during the months of August through December.

An interesting characteristic of both the Helmand and Arghandab Rivers is the large variation in annual discharge from year to year. On the Helmand, maximum spring runoff was about six times larger than the minimum spring discharge (fig. 15); on the Arghandab, the maximum discharge was about eight times larger than the minimum (Brigham, 1964). The highest average monthly flows occurred in April on both rivers, but the largest monthly discharges did not occur in the same month: maximum flows took place in May on the Helmand and in April on the Arghandab. This difference may be due to later snowmelt in the higher Helmand Valley headwaters or to late spring storms that did not penetrate far enough east into the Arghandab drainage basin.

Annual discharges of the Helmand and Arghandab Rivers from 1948 to1975 are shown in figure 16 (Brigham, 1964; Childers, 1974; U.S. Agency for International Development, 1976). The 25-year average annual discharge of the
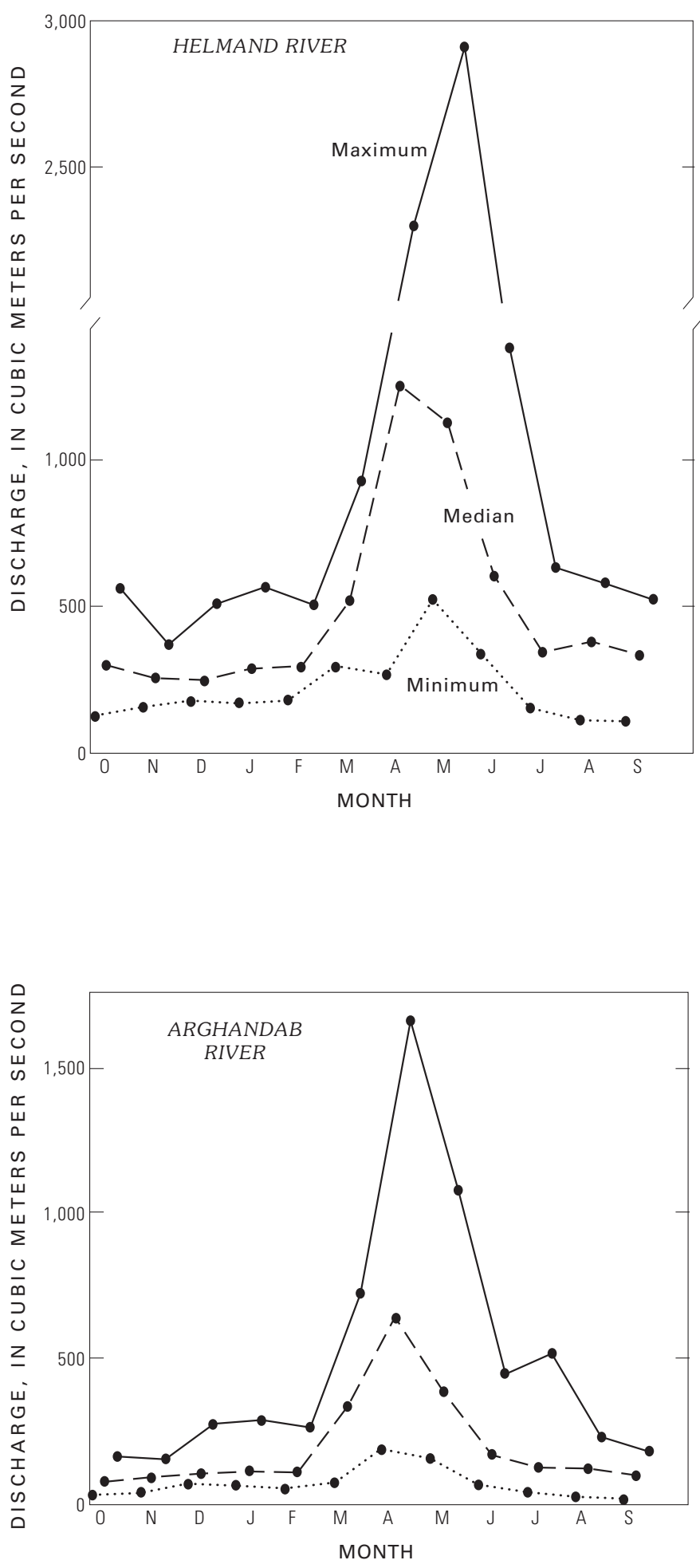

Figure 15. Monthly maximum, median, and minimum discharges of the Helmand River from the Kajakai Reservoir and of the Arghandab River from the Arghandab Reservoir. 


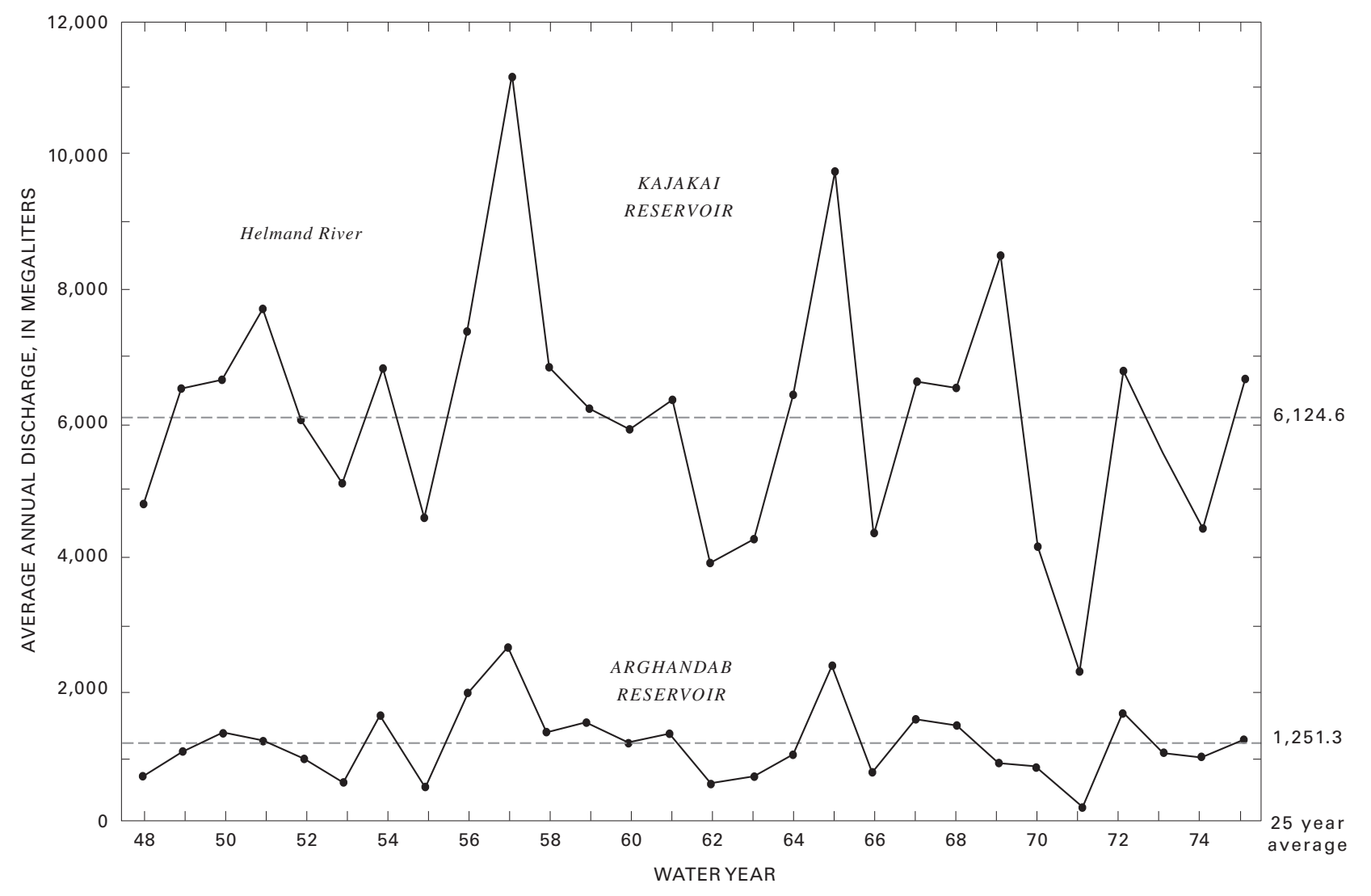

Figure 16. Average annual discharge of the Helmand River from the Kajakai Reservoir and of Arghandab River from the Arghandab Reservoir: 25 years of data compiled from Brigham (1964), Childers (1974), and U.S. Agency for International Development (1976).

Arghandab is $1,251.3$ megaliters and the Helmand River discharge is 6,124.6 megaliters, about five times more water than flows down the Arghandab River. Annual discharge has varied by a factor of five over 28 years of continuous record on the Helmand, and the pattern of yearly discharge is very irregular. Years of average flow are not common; in fact, abrupt differences in total discharge from year to year are the rule. Thus, the erratic behavior of the Helmand and the Arghandab is a characteristic of these streams; droughts and floods are not rare events in the lower Helmand Basin. All available stream discharge data for the Helmand Basin have been digitized and are available on the USGS Web site http://afghanistan.cr.usgs. gov/gagingstations.asp (access date August 21, 2005).

The irregularity of precipitation events in the Hindu Kush Mountains is illustrated in figure 16. During 1951, 1964, and 1969 , major increases in annual discharge took place in the Helmand Basin but not in the Arghandab Basin; whereas, during 1959 and 1974, the Helmand River experienced decreases in flow from the year before, while flows in the Arghandab River remained the same or increased slightly. However, there was likely some control of outflow from the dams on these rivers.

The large variation in month-to-month discharge and the variation in annual discharges are common characteristics of streams in arid regions. The unpredictability of streamflow from year to year has a marked effect on the inhabitants of Sistan. During dry years, inhabitants in the lower valley and on the delta suffer great hardship; not only do they lose most, if not all, of their crops that year, but the low spring runoff may also result in the destruction of agricultural fields and choking of irrigation channels by increased deflation and moving dunes. The British tell of great swarms of insects that hatched when the hamuns dried up in 1902, which made life nearly unbearable and caused a great loss of animal life in Sistan (McMahon, 1906; Tate, 1910-12). Unusual outbreaks of insects may well have been responsible for episodes of pestilence in the past.

Sistan residents must adjust to regular flooding as well as to droughts. Floods are potentially more destructive than droughts because they can occur without warning and quickly destroy life and property. The destruction of canals, channels (juis), villages, and fields can be substantial.

A sudden temperature increase in a year of heavy snowfall or a sudden warming combined with a large precipitation event in the upper drainage basin can create very high magnitude floods in the Helmand Valley and on the delta. Annual peak discharges on the Helmand River at Chahar Burjak are summarized in figure 17. For available data through 


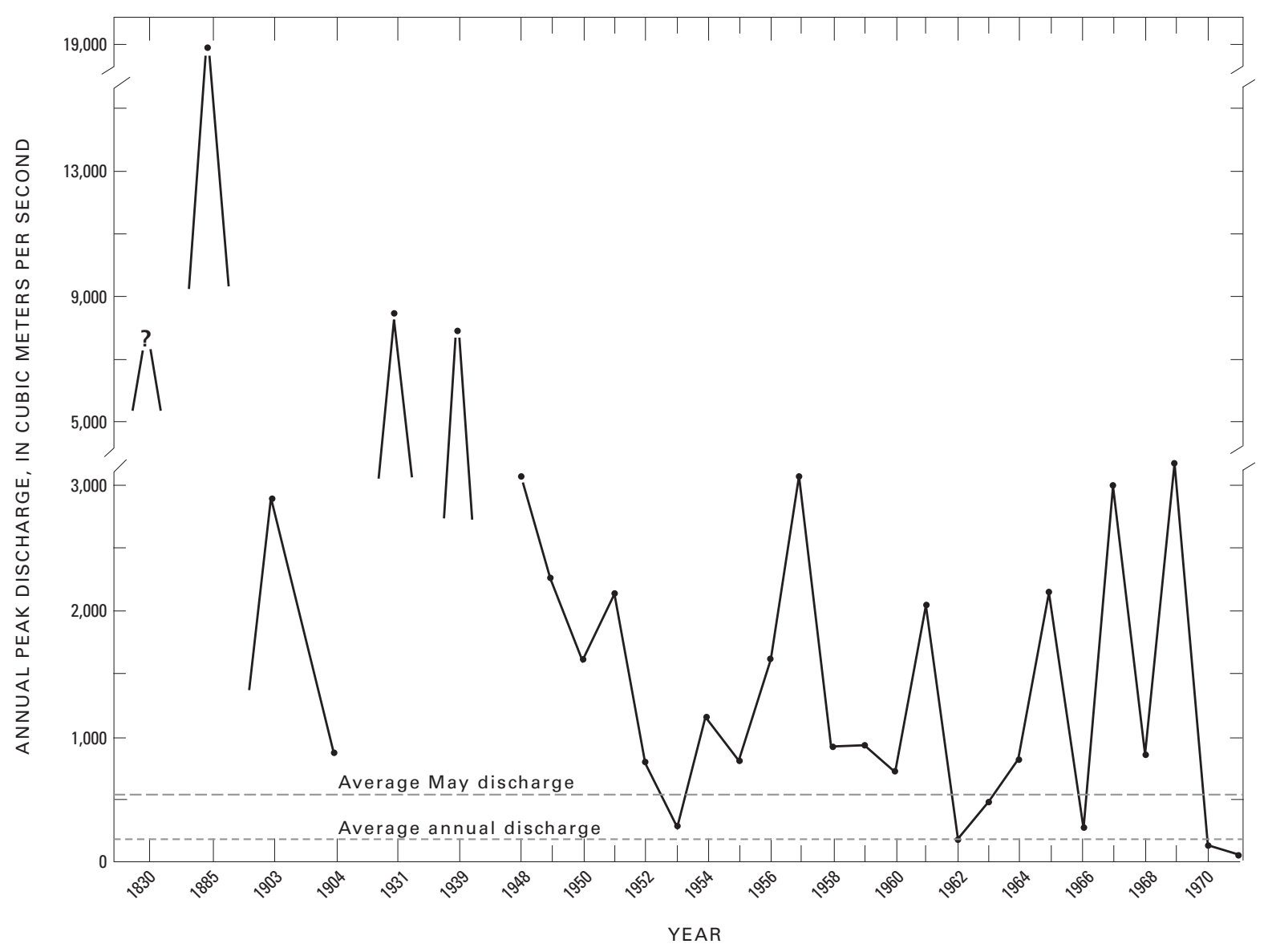

Figure 17. Annual peak discharges of the Helmand River at Chahar Burjak.

1970 annual peak discharges range from a low of 80 cubic meters per second in 1971 to a high of 18,917 cubic meters per second (668,000 cubic feet per second, English units) in 1885 (Ward, 1906; International Engineering Co., 1972; U.S. Agency for International Development, 1976). At least eight floods during the 20th century had peak discharges of 3,000 cubic meters per second or more and were at least 6 times larger than the average May flood discharge on the Helmand. These flood years stand in contrast to 6 years between 1948 and 1971 when peak discharges were less than the average May discharge; once every 4 years, large spring floods did not occur.

The destructive effect of high flood discharges is enhanced because of the very low stream gradient in the lower Helmand Valley and on the delta. The average gradient from the Rudbar area to the Hamun-i Puzak is 0.00035 , or a drop of 0.35 meter per kilometer. Also shown on the profile are elevations of the water in the valley at Chahar Burjak during peak flood discharges of 10,000 and 24,000 cubic meters per second. These flood levels decrease in height downstream as the valley opens onto the delta, but they emphasize the effect of large floods on the distributary channels. At the junction of the Helmand and Rud-i Biyaban, the water depths of these floods, which are approximately equivalent to the 80- and 200-year floods, are estimated to be about 7.5 meters and 10.5 meters, respectively, above the present channel on the basis of the valley width at Chahar Burjak (International Engineering Co., 1972). Discharges of this magnitude will flood all distributary channels on the old and new deltas and cause significant damage and, most likely, extensive loss of life.

\section{Flood}

The closed depression of Sistan contains four shallow basins that receive the Helmand discharge. Three basins lie along the edges of the delta: Hamun-i Puzak on the northeast, which also receives water from the Khash Rud and Farah Rud; Hamun-i Sabari to the north with its large surrounding wetlands (Naizar); and Hamun-i Helmand to the west. South of the present delta is a separate and lower depression that contains the Gaud-i Zirreh, which receives floodwaters only when the other three hamuns fill, merge into one very large lake, and overflow southward through the normally dry Shela Rud (fig. 2). Floodwaters fill the Gaud-i Zirreh infrequently, on the order of once every decade or two. Satellite images of the depression, however, do show small amounts of water in the Gaud-i Zirreh in some nonflood years, which indicates that 
ground water seeps into that basin from the alluvial fans in Baluchistan to the south.

During the late $19^{\text {th }}$ century Britain offered to arbitrate international boundary issues in Sistan between Iran and Afghanistan. In 1872 the British Commissioner, Major General Goldsmid, presented the lands of Sistan east of the Helmand River below the village of Kohak (a former village near the present Khwabgah in fig. 2), including the three eastern hamuns, to Iran. Lands to the west of the Helmand and much of the northern delta were awarded to Afghanistan. Both countries accepted this division of land; however, in 1896 the Helmand and a couple of tributaries changed their courses during a flood and reignited land and water disputes between the countries. So, in 1903 a second British mission was dispatched to Sistan from India to once again arbitrate the boundary and water disagreements. This mission stayed until 1905 and did thorough studies on the delta, lakes, hydrology, and history of the area (McMahon, 1906; Tate, 1910-12; Ward, 1906). The collection of detailed geographic and hydrological data by T.R.J. Ward (1906) in his Revenue and Irrigation Reports to the British Government is an unsung classic in desert literature. Unfortunately only a handful of copies of these documents were published, and they were originally classified "Secret." This commission suggested that Iran receive one-third of the total volume of the annual Helmand River discharge and warned that future changes in the position of the lower Helmand and its distributaries were likely. Both countries refused to accept the commission's suggestions. In 1972 an agreement between Iran and Afghanistan was written that would provide 26 cubic meters per second to Iran from the Helmand; however, the Afghan Government never ratified this agreement. Friction over water deliveries to Iranian Sistan has continued to the present (2006) and has become especially contentious during droughts.

Ward and his crew of Indian surveyors measured many hydrologic properties in Sistan in order to characterize the Helmand River and available water on the delta and in the hamuns. They even measured daily flows into Sistan from 1903 to April 1905 on all streams entering the depression (by soundings on boats) and calculated volumes for each lake through detailed land surveys. Water years 1903 and 1904 were then compared to the extraordinary flood in 1885 (table 1; Ward, 1906, p. 48). Local residents and earlier travelers through Sistan described the unusual 1885 flood, and high water marks from the flood and hamuns were still visible in 1903. Ward reconstructed discharges for the 1885 flood by calculating the cross-section area of the flow in the lower Helmand Valley just above the delta (downstream from Chahar Burjak village) and in a few distributaries. Flood heights for the 1885 flood were 4.6 meters (15 feet) higher than those during 1903. During the flood a new distributary, the Rud-i Pariun, was excavated by flood scour of a former canal. Calculated discharge in cusecs (cubic feet per second) at four sites on the lower Helmand ranged from about 650,000 to 693,000 cubic feet per second $(18,406-19,624$ cubic meters per second). No flood of similar size or even half that magni- tude has occurred on the Helmand up to year 2006, although Ward (1906, p. 46) mentions a flood in 1830 (fig. 17) that was believed to be almost as large as the 1885 flood.

The 1885 flood filled all four hamuns to overflowing and merged them into one huge lake, which, in turn, overflowed and spilled southward through the Shela Rud (also Rud-i Shela, fig. 2) and created a lake in the normally dry Gaud-i Zirreh basin. Average hamun depths in 1903-1905 were 1.21.5 meters (4-5 feet) with maximum depths of 3.7-4.9 meters (12-16 feet). During the 1885 flood, based on mapping of the 1885 lake level, the hamun average depth was 2.4 meters (8 feet) and maximum depth was 5.8-6.4 meters (19-21 feet). At these depths, the lake overflowed into the Gaud-i Zirreh. In normal years, water depths in the Gaud-i Zirreh are $0-1.8$ meters ( $0-6$ feet); during 1885 the lowest point in the basin contained a water depth of 10.4 meters (34 feet), and the lake lasted for about 3 years before it completely evaporated. A total of 24.9 million acre-feet or 30 billion cubic meters of water flowed into the hamuns during April 1885 (Ward, 1906). The overflow channel into Gaud-i Zirreh, 10.7 meters (35 feet) deep and 304.8 meters (1,000 feet) wide, was active for nearly 2 years before drying up.

\section{Water Quality}

One important aspect of the Helmand River is its very low content of total dissolved solids (Anderson, 1973; Forster, 1976; Perkins and Culbertson, 1970). Water purity is probably the major reason why salts do not concentrate heavily in the hamuns. The hamuns are normally about 1.5-3.0 meters deep and will overflow into the Gaud-i Zirreh after their depth increases an additional 1.5 meters. However, if the very high evaporation rates on the delta area are accurate, then some salt concentration is expected. One possible explanation for the relatively fresh water is that some alkaline salts are drawn down into the ground water. Alternatively, several investigators believe that the salts are dissolved during periods of high flow, are flushed into the Gaud-i Zirreh, and then deflated out of the basin when the hamun is dry (McMahon, 1906; Anderson, 1973; Jux and Kempf, 1983). Deflation of salts probably occurs more frequently because the hydrologic records of the Helmand River indicate that the individual hamuns drastically shrink, or completely dry up, once or twice a decade, which is more frequent than previously described. Another possibility is that salt is rapidly buried by a high sediment influx during floods. In any case, the Sistan hamuns remain the only free-standing bodies of relatively fresh water in Southwest Asia that are not artificially created or located in mountainous terrain.

\section{Channel Changes in the Sistan Depression}

The Helmand River enters the Sistan depression about 20 kilometers downstream from the village of Chahar Burjak. At this location the Helmand bifurcates into two channels: 
Table 1. Calculations of flood discharges for the 1885, 1903, 1904, and 1905 floods by T.R.J. Ward.

Siatemient showing the results of the maximum food discharges calculated from the surface slope of the flood line and the area of the flood section. N. B. - The value of Kutter's $N$ used was 'o.3o.

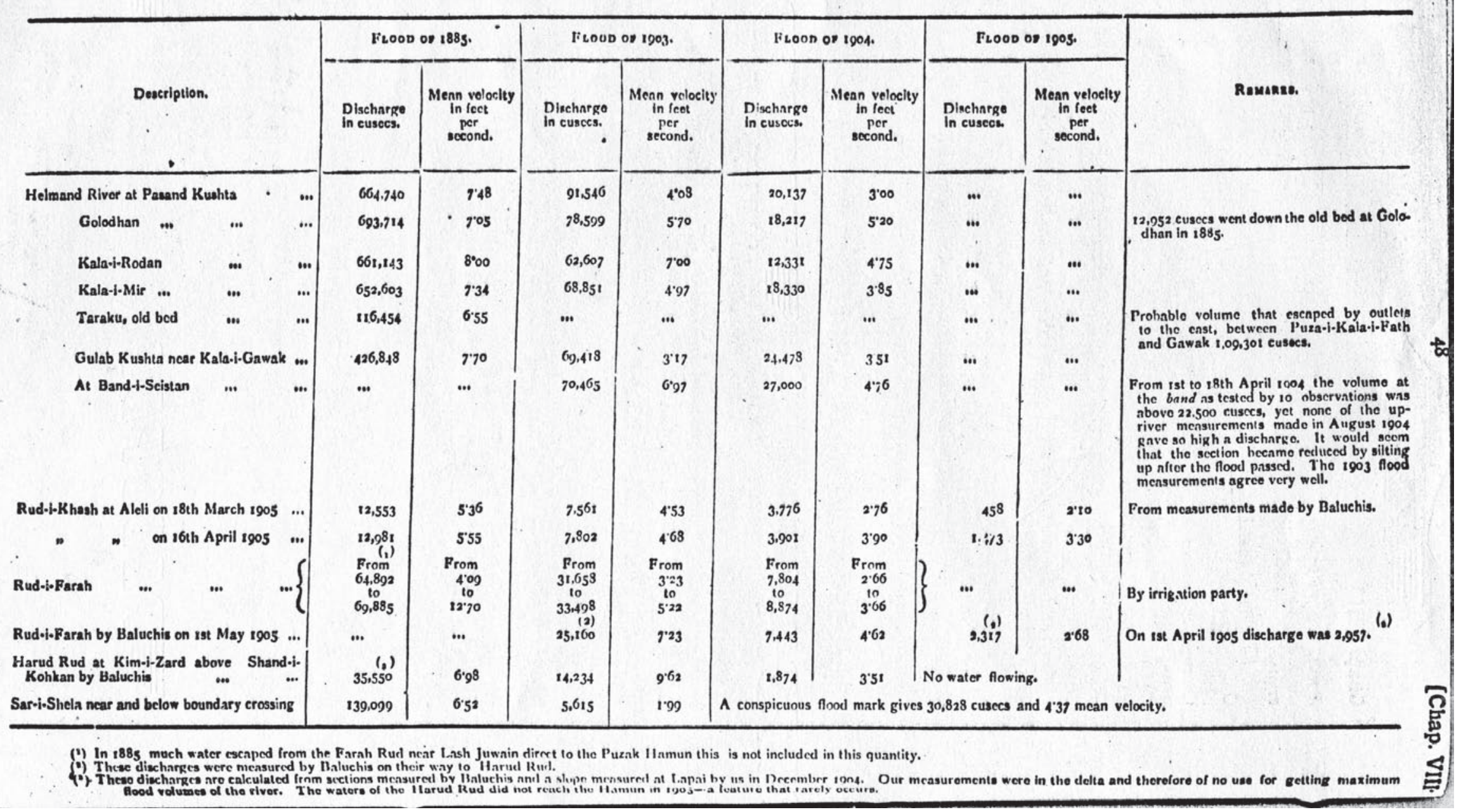


the Rud-i Biyaban, which flows west, and the main Helmand channel, which flows north. About 18 kilometers farther downstream another distributary stream, the Sana Rud (also spelled Sena Rud), branches off to the northwest from the main Helmand channel. The Rud-i Biyaban and the Sana Rud are incised about 15-30 meters below a low, erosional, gravel plain that is confined on the east by the Helmand River Valley. The deltaic shape of this erosional plain suggests that it is the surface of an old delta of the Helmand; the deltaic streams are incised because continued subsidence of the depression has lowered their base level.

The main Helmand channel continues north to the village of Khwabgah, where the flood plain is no longer confined by a high valley wall on the east. Just beyond Khwabgah, the edge of the "old delta" on the west terminates in an erosional scarp (possibly a fault scarp), and the Helmand enters the "modern delta," a region locally referred to as "Sistan Proper" because the majority of the population live on this plain.

At the head of the modern delta, just south of Khwabgah, the Helmand is divided into two channels by a modern dam (the Band-i Sistan): the Rud-i Sistan, which flows into Iranian Sistan, and Shelah Charkh, which flows north to Zaranj and then northwest into the Hamun-i Puzak. The present distribution of Helmand waters on the modern delta is well controlled against all but the most severe floods because the river is now regulated by three dams and distributed through several irrigation schemes. Sedimentation in these reservoirs and channels, however, is expected to decrease due to regulation of Helmand discharge by releases from Kajakai Dam (Perkins and Culbertson, 1970). Before the large dams were built in the early 1950s, channel changes in the Sistan depression were frequent. In fact, it is not an exaggeration to say that the human history of Sistan is a history of human struggle to control the deltaic distribution of the Helmand River (Whitney and Trousdale, 1982).

Deltaic processes were described by the Arab geographer Istakhri, who visited Sistan about A.D. 900. He wrote about the change of the provincial capital: "It is said that the ancient capital of the province, in the time of the first Persian dynasty, was. . .named Ram-Shahristan, and the canal of Sejestan (Sistan) flowed to it; but owing to the bursting of the dyke on the Helmand, the water of this canal was lowered and cut off from it, so that its prosperity diminished, and the inhabitants removed from it and built Zaranj" (Rawlinson, 1873). Water on the 10th century delta was distributed by seven major canals and channels; agriculture and habitation on the delta were robust.

The changing position of stream channels and important canals on the delta was noted by several 19th century British explorers and military officers and is illustrated in figure 18. In 1840, Conolly reported that a similar catastrophe had befallen occupants on the western delta; a major flood in 1830 had caused the Helmand to abandon a west-flowing channel (labeled 1800 in figure 18) and to occupy a small east-flowing branch or canal (labeled 1830-40 in figure 18) that was scoured during the flood. Although the inhabitants tried to reclaim the old channel by building a mound in the new one, the next flood washed away their efforts and the river remained in the new channel. Thus, the channel change forced another local population shift. Chaos on the delta probably followed major channel changes: efforts to reclaim a channel or build new canals to old fields; agricultural losses; construction of new villages and forts to protect them; digging new canals and preparing agricultural fields; and certain political strife among land-holding tribes when old channels became uninhabitable. Similar desert relationships of early societies to shifting stream channels have occurred on other rivers in Central Asia (Gerasimov, 1978).

The Helmand River changed its principal deltaic channel three more times before the Rud-i Pariun was established in 1896 (Sykes, 1902; Tate, 1910-12). In fact, the 1896 channel change created an international furor because the border between Afghanistan and Iran was partly located along the former channel (labeled 1866-96 in fig. 18) (Goldsmid, 1876; McMahon, 1906). The Rud-i Pariun persisted as the main channel until the early 1950s, and by 1954 the Helmand was flowing in its present channel, the Shelah Charkh.

The channel change to Shelah Charkh was partly caused by dam construction in 1953 across the Rud-i Sistan to control water distribution in Iranian Sistan. Diversion of floodwaters apparently caused increased scour in the Shelah Charkh; this scour deepened the channel, which resulted in less discharge in the Rud-i Pariun. The deeper channel also caused agricultural problems because the channel was downcut below the irrigation diversions, necessitating expensive rebuilding of takeoff canals (International Engineering Co., 1972). Dunes were noted in the Rud-i Pariun channel, but it is not known if the dunes were emplaced before or after the channel change.

The pre-19th century channel history is more difficult to reconstruct. Rawlinson (1873) described some of the canals and channels that are mentioned in the writings of early geographers and historians, and these channel positions are included in figure 18. The position of channels during the times of earlier civilizations is based on archeological site locations. Fairservis (1961) plotted the location of presumed Achaemenid and pre-Achaemenid sites in Sistan on the basis of his studies in Afghanistan and those of Stein (1928) and Hedin (1910) in Iran. The earliest known sites in the Sistan depression are Khaima Barang, which is located along the lower Shela Rud (fig. 2), and Shahr-i Sokhta in Iran (fig. 18). Both of these sites were supplied by water that came down the Rud-i Biyaban. Khaima Barang was discovered by the Smithsonian Institution's Helmand-Sistan Project in 1976. Charcoal from this unexcavated site was radiocarbon-dated at 5,925 \pm 65 years before present (lab no. SI 3164). Shahr-i Sokhta, discovered by Stein (1928) and excavated by an Italian team (Tosi, 1973, 1976), was occupied from 2800 B.C. to 1500 B.C., which is roughly equivalent in age to the Indus Valley civilization. Archeological surveys in Afghan Sistan have failed to find sites older than 1500 B.C. on the modern delta or on the adjacent Sar-o-Tar plain, which suggests that the Rud-i Biyaban was the principal distributary during the 


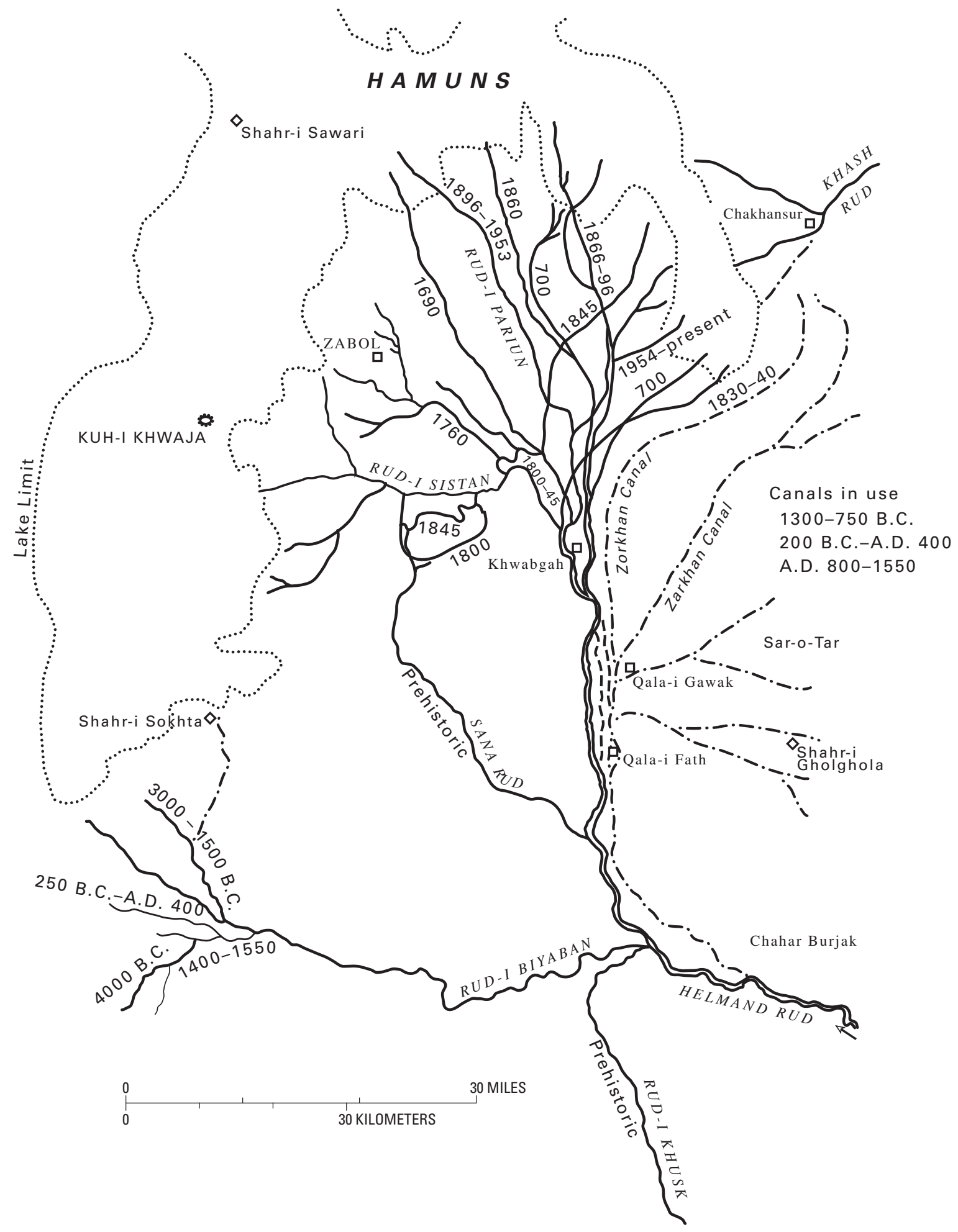

Figure 18. Channel changes on the Helmand River delta in the Sistan depression. 
middle Holocene. It should be emphasized, however, that the delta region has not been extensively surveyed. It is possible that pre-1500 B.C. sites exist but will not be recognized until some of the large, unexamined sites (tepes) are excavated, because younger settlements were commonly constructed over ruins of earlier cultures.

The earliest archeological evidence of water flowing in the main Helmand channel toward the modern delta is derived from three sites on the Sar-o-Tar plain, discovered by the Helmand-Sistan Project; these sites were inhabited as early as 1300 B.C. The abandonment of Shahr-i Sokhta about 1500 B.C. and the occupation of the Sar-o-Tar plain about 1300 B.C. suggests at least one major channel shift from the Rud-i Biyaban to the main, north-flowing Helmand channel sometime in the intervening 200 years; in fact, a major channel shift to the modern (northern) delta may have been a primary reason for the abandonment of Shahr-i Sokhta.

Archeological surveys and excavations by the Helmand-Sistan Project identified three periods of occupation on the Sar-o-Tar plain: 1300 B.C.-750 B.C., 200 B.C.-A.D. 400, and A.D. 800-1550. Canals were extensively used during each period, and many of the younger canals either followed older canal traces or the older canals were reused. ParthianSassanian sites (250 B.C.-A.D. 400) are also found on the Rud-i Biyaban delta (fig. 18), which indicates that water was flowing in both the main Helmand Valley and Rud-i Biyaban at that time; the larger concentration of Parthian-Sassanian sites on the modern delta and Sar-o-Tar plain would seem to indicate that the main channel flowed north, while the Biyaban sites were supplied by a major diversion canal. A similar situation existed during medieval Islamic times (A.D. 14001550); a small number of Timurid sites were built in the Rud-i Biyaban Valley and along the Shela Rud, while hundreds of Timurid buildings were constructed on the modern delta and on the Sar-o-Tar plain.

Channel changes during historical times were undoubtedly far more complex than it is possible to reconstruct from the fragmentary archeological and written records. The frequency of natural channel change indicates that the processes causing these changes were not controlled by long-term factors, such as climate change or tectonic activity, although individual events, such as a decade-long drought or a local fault movement in a stream valley, may have contributed to a specific channel change. Instead, the processes that cause the Helmand to shift channels are channel aggradation, common on all low-gradient deltas, and the frequent high-magnitude floods that characterize this desert basin. Conolly (1840) described this process of channel change in 1840:

It requires but little knowledge of physical geography, to judge of the effect of a large body of water discharged in this manner, with varying velocity, into a basin, incapable, from its nature, of offering the slightest resistance to its progress. The water hurries away to the lowest spots, and there, when its turbulence has subsided, drops its load of earth, till in the process of time these low spots have become elevated, and the water is driven to some other place. It necessarily results, that the level of the country must constantly be altering, and that as the whole bed of the lake is thus gradually filling up, the waters spread themselves over a large surface every year. This extension is much assisted by the deposits which take place in the beds of the rivers at their mouths, which deposits are of course ever on the increase as the current becomes less rapid, when layer after layer of settling earth diminishes the slope. In consequence of this filling up of their beds, nearly all these rivers overflow their banks on entering Seistan.

The behavior of the lower Helmand River in historical times demonstrates that major hydrologic changes took place that directly affected the survival of ancient settlements in the Sistan depression; furthermore, these changes were not uncommon and were not ostensibly controlled by an external factor such as climate change. Channel change, or channel shifting, is a natural process during the growth of a delta.

\section{The Helmand Valley Project}

"In Seistan, as in Egypt, there is no cultivation without irrigation, both owe their existence to the fertility brought to an almost rainless tract by surplus waters of a far distant catchment..." (from the introduction to T.R.J. Ward's 1906 study of the lower Helmand River, delta, and lakes in Seistan for the Afghan Commission).

Numerous visitors to the lower Helmand Basin in the 19 th and early 20 th centuries were impressed by the remnants of vast irrigated fields and archeological ruins along the Helmand Valley and especially in Sistan. People have been living in the lower Helmand Basin for over 5,000 years (Dupree, 1980). The Government of Afghanistan became interested in expanding agriculture in the 1930s, and a few ancient canals were rebuilt by German and later Japanese engineers in the middle Helmand Valley. The Afghan Government continued canal construction during World War II and hired the American firm of Morrison-Knudsen, Inc. in 1946 with U.S. Government funding to build two diversion dams on the Helmand and Arghandab Rivers, to enlarge canals, and to build roads in the valleys (Caudill, 1969; Zakhilwal, 2004). The Afghan Government put a strong emphasis on the project in hopes of resettling a large portion of the nomad population and augmenting agricultural exports, as well as supplying electrical power to the southern provinces in order to modernize the country.

Afghanistan found itself the beneficiary of Cold War politics between the Soviet Union and the United States. During the 1950s and 1960s Afghanistan "received one of the highest levels of per capita aid of any country in the world"-about \$1.2 billion up to 1972 (Nyrop and Seekins, 1986, p. 147), which is equivalent to over $\$ 7.4$ billion in 2005 dollars. After World War II the U.S. Government took an interest in underdeveloped, independent nations and used the Tennessee Valley Authority (TVA) as a model for economic development 
(Cullather, 2002). U.S. aid and assistance focused on three areas: transportation and communications, infrastructure, and agricultural development. The United States concentrated development efforts in the southern half of the country, primarily the lower Helmand Basin, while the Soviet Union created and oversaw projects in the north, including oil and gas exploration and development.

Work in the Helmand and Arghandab Valleys, known as the Helmand Valley Project (HVP), was the largest agricultural development project in the country and in the early 1950s was financed by U.S. Technical Assistance Grants (fig. 19). Morrison-Knudsen, Inc., completed the 44.2-meter-high (145 feet) Arghandab Dam with its storage capacity of 388,000 acrefeet of water (18 miles northeast of Kandahar) in 1952. A few months later in April 1953 the Kajakai Dam (72 miles upstream from Lashkar Gah) was finished. The rock-fill dam was 91.4 meters high (300 feet) and 26.5 meters long ( 87 feet) with a 51.5-kilometer-long (32 miles) reservoir and a capacity of almost 1.5 million acre-feet of water (fig. 20). Before the dams were constructed, appropriate soil and topography studies were not conducted before designing irrigation tracts on new (previously not irrigated) lands designed for agricultural development (Michel, 1972). A 1950 United Nations report (cited in Zakhilwal, 2004) cast doubt on the economic soundness of the project, and later Bureau of Reclamation engineers cautioned that the project would require "extraordinary (that is, expensive) protective installations (soil drains) and maintenance, and extensive releveling of the newly irrigated lands" (Bureau of Reclamation, 1954).

Two negative effects occurred relatively quickly when irrigation waters were spread across both new and traditional agricultural lands. A strongly cemented conglomerate underlies the newly irrigated lands and impeded infiltration of irrigation waters which in turn caused the local water table to rise 4.9 meters (16 feet) within 3-4 years of opening the main Boghra canal (Michel, 1972). Because of high evaporation rates and lack of persons experienced in irrigation management, large areas of the new lands became salinized and unsuitable for farming. In other areas, especially on traditional agricultural lands, increased water on the land resulted in waterlogging and loss of crops. The Bureau of Reclamation was brought in to install drainage systems and redesign some of the irrigation schemes, and some of these salinized and waterlogged lands were reclaimed. The U.S. Geological Survey set up surface- and ground-water monitoring programs (Taylor, 1976), and this work continued until the United States was forced out of the country in the late 1970s.

The Helmand Valley Project cost roughly $\$ 150$ million (about $\$ 850$ million in 2005 dollars), half of which was directly financed by the United States (Clapp-Wincek, 1983). Of the target of 540,000 acres to be irrigated in the project, about 170,000 (31 percent) received irrigation water by the

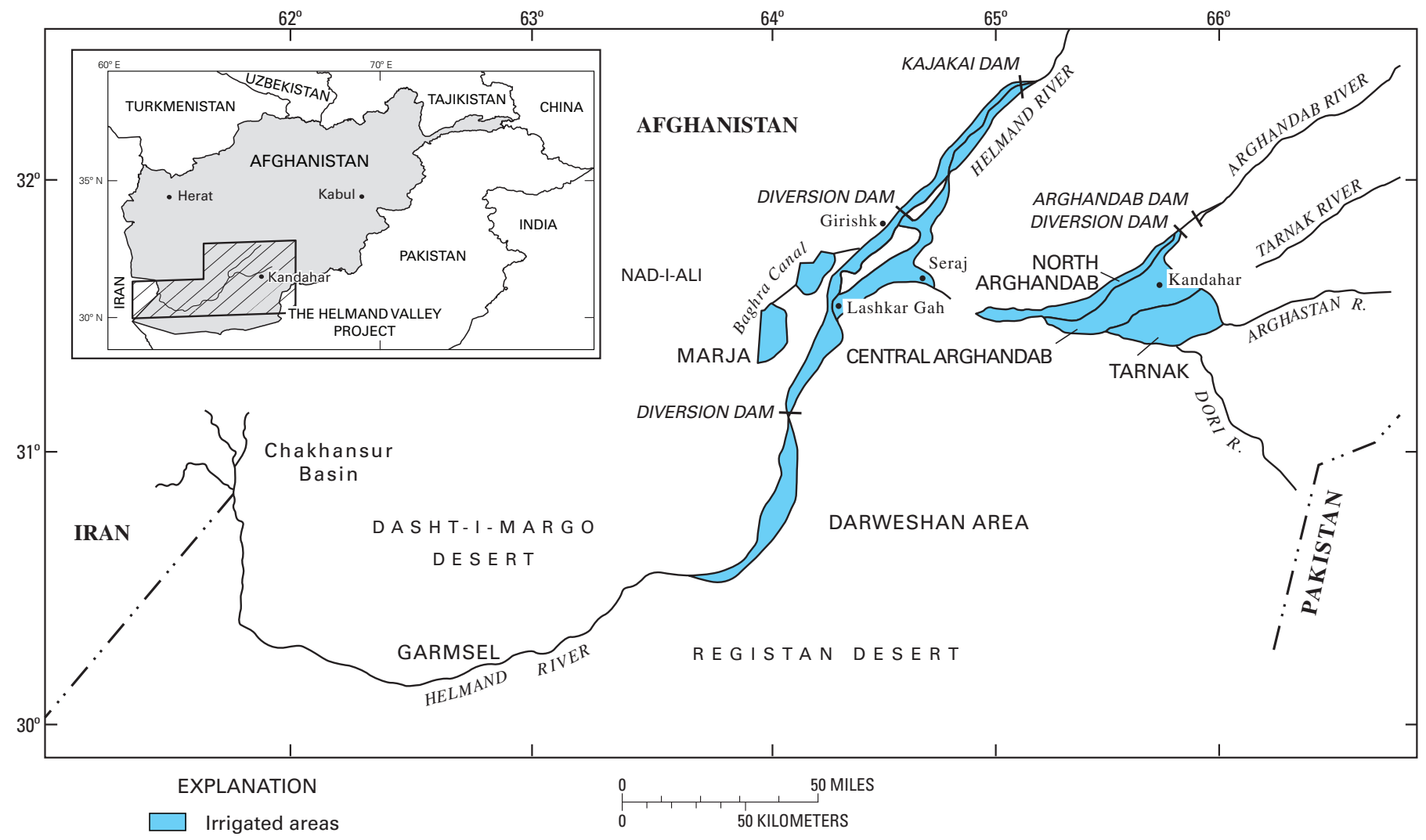

Figure 19. Map of agricultural lands irrigated by the Kajakai and Arghandab Dams of the Helmand Valley Project. Modified from Michel (1972). 
Figure 20. Kajakai Reservoir on the Helmand River in 1976. View is upstream.

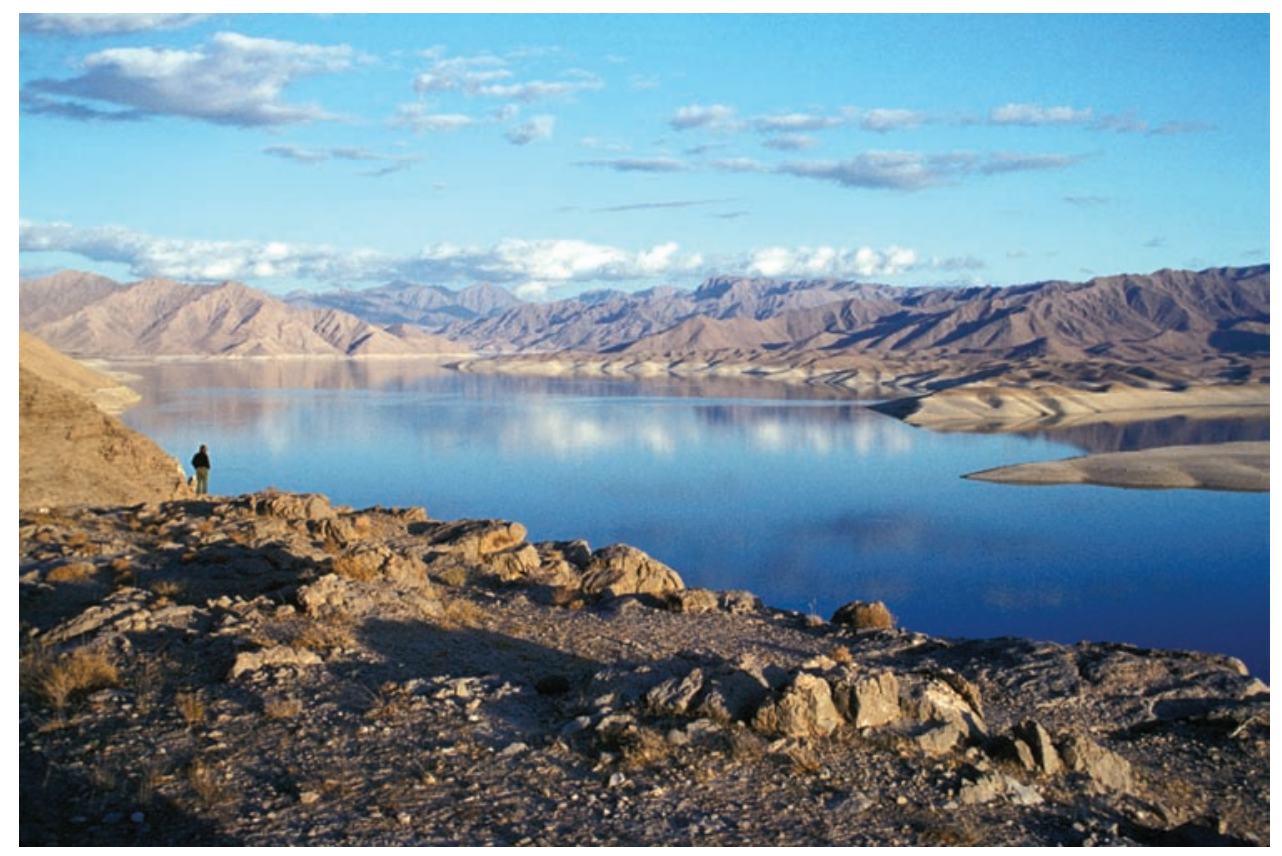

mid-1970s, and some of those lands were previously under cultivation (Zakhilwal, 2004). By 1970, HVP lands were producing 100,000 tons of wheat per year. This amounted to only 4 percent of the national wheat production, yet the project consumed over one-third of the total public investment in agriculture (Nyrop and Seekins, 1986). By the mid-1970s, however, the region was producing cotton, fruits, and nuts for export, although the volumes were not as high as anticipated.

More than 2 decades of war and intense political strife have left Afghanistan as one of the poorest nations on Earth. The principal Helmand Valley cash crop during the early years of the 21st century is opium. Since the late 1990s, Afghanistan is the world's largest producer of opium (more than 80 percent of 2004 world supply) and has become the major supplier of heroin to Europe. In 2003 opium brought in $\$ 1.2$ billion to Afghanistan, roughly one-half its gross domestic product (Robyn Dixon, Los Angeles Times, October 5, 2003). In 2002 the Helmand Province had 30,000-35,000 hectares under poppy production, the most of any province in the country.

No HVP provisions or plans were made for improved irrigation on the Helmand delta in Sistan, site of several former civilizations (Tate, 1910-12; Tosi, 1973). Several negative effects of the dams and water distribution schemes in the lower Helmand Valley and the delta were, in fact, observed by the author during the mid-1970s. The foremost effect in the valley was increased incision by the Helmand River into its flood plain due to decreased sediment delivery and lower discharges in the river. Villagers and farmers were forced to extend their irrigation canals several kilometers upstream in order to bring water up onto the flood plain (fig. 21). Water and sediment trapped behind the dams has also affected the delta. Smaller volumes of water to the delta have resulted in shrinking hamuns and adjacent wetlands, especially in drier years when a greater proportion of the annual discharge has been withheld upstream. Less water also results in lower water tables on the main delta and poorer water quality. More lands have experienced salinization, and lack of fresh annual sediment has decreased soil fertility. Another consequence of less water on the delta is less vegetation holding the soil: local residents interviewed in 1977 claimed that sand movement across deltaic agricultural lands (fig. 22) had increased since the dams were completed. These negative environmental effects in the lower valley, along with waterlogging and salinization downstream from the dam, have not been calculated as indirect costs of the Helmand Valley Project.

During the first 15 years of operation, the Kajakai reservoir received an annual average of 194 cubic meters per second of water and trapped an average of 9,625,060 cubic meters of sediment ( $340 \times 10^{6}$ cubic feet) (Perkins and Culbertson, 1970). If patterns of discharge on the Helmand have been roughly the same since the late 1960s, then about 405,860 acre-feet of sediment has accumulated behind the dam by 2005 , which implies that storage capacity has decreased by 27 percent.

\section{An Unknown Future}

This report presents an overview of the geology, hydrology, and climate of the lower Helmand Basin - an earth science base upon which future studies can improve both knowledge and resource management in southern Afghanistan. Nearly all the work discussed here was accomplished before 1980 because Afghanistan has been through nearly 


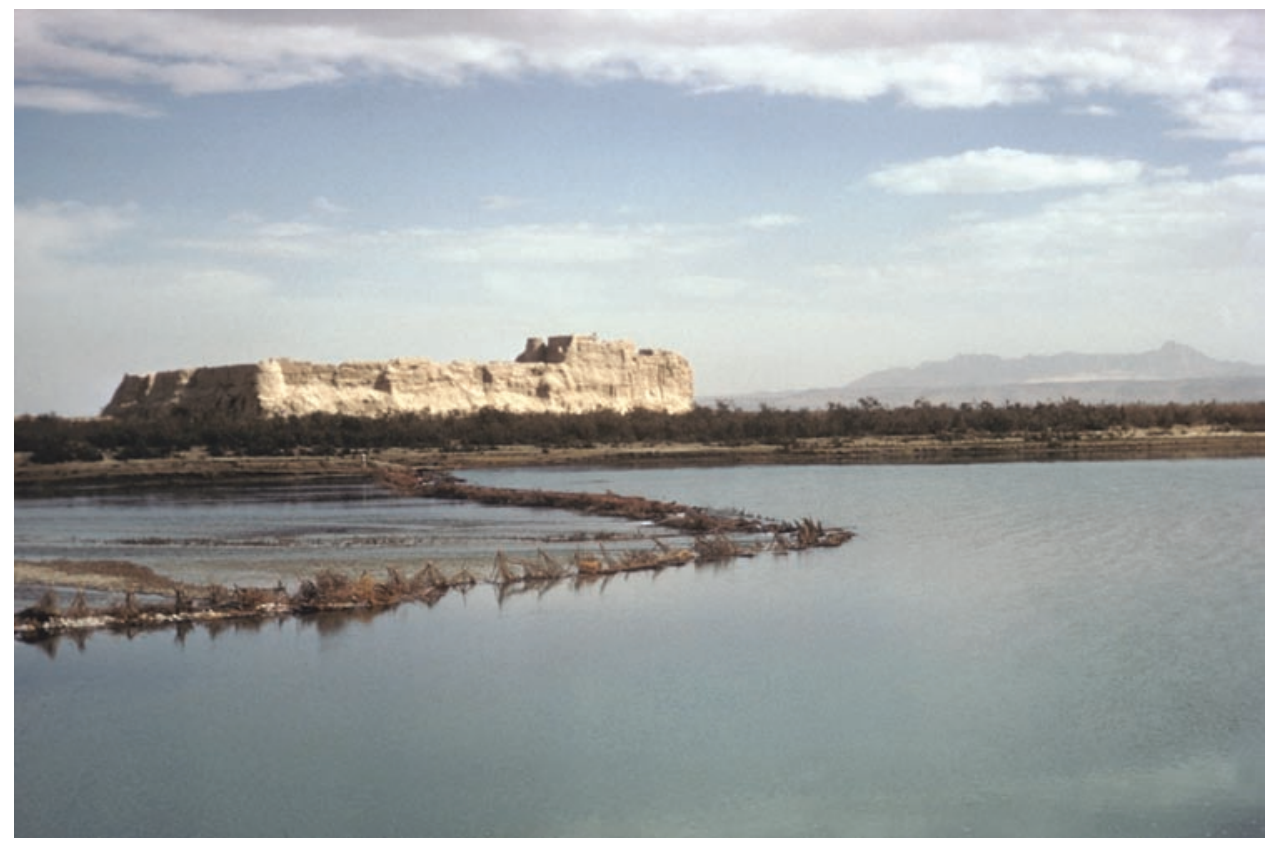

Figure 21. A tamarisk band (a porous dam) on the Helmand River raises the water level in order to irrigate on the flood plain.

constant political and civil strife for the past 25 years. One of the poorest nations in the world, the country has been at or near survival-level conditions for a generation. Much time and effort are needed to rebuild the nation's technical infrastructure before new insights can be gained into the geology and geomorphology of the lower Helmand Basin.

Few details of the geologic history of the lower Helmand Basin are available. Exposed basin fill and dated volcanic rocks are of Neogene age, and the southern part of the basin has continued to subside throughout the Quaternary to form the Sistan depression. The active faults bounding the southwestern basin and depression are located across the international boundaries with Iran and Pakistan and are yet to be studied in detail. Sistan receives the discharge of the Helmand River, which supplies a semicircular chain of hamuns around the north end of the delta. Delta position and stream incision have responded through the late Quaternary to active subsidence in the depression. Scour by the unusual wind conditions unique to Sistan and eastern Iran has deflated dry lakebeds and flood deposits and spread vast seas of eolian sand across the southern and eastern parts of the basin. Planned airborne geophysical surveys of the Helmand Basin in 2006 by the USGS will provide new data for an improved picture of the basin tectonic setting and for oil and gas resource assessment.

The Helmand River and its tributaries are the lifeblood of southern Afghanistan. Water supports Kandahar, the second largest city in the country, and the irrigated fields along the Helmand and Arghandab Rivers provide food for much of the country. Thirty years ago, agricultural products from the lower Helmand Basin were abundant enough to be one of the major sources of foreign exchange for the country. Now, out of desperation, the main source of foreign exchange is opium.
Rebuilding a sustainable agricultural economy of southern Afghanistan is a high priority of the Afghan Government. In order to accomplish this goal, management of the surface and ground waters in the lower Helmand Basin, along with improved agricultural methods and land reclamation, will be critical.

Sistan was home to many historic civilizations; however, the delta region was left out of the first Helmand Valley Project. A reevaluation of and reinvestment in the agricultural potential of Sistan may provide more productive agricultural lands for the country. Maintenance of the hamuns and extensive wetlands around the delta would help to preserve the unique ecological setting and niche for human inhabitants, birds, and animals (United Nations Environment Programme, 2006).

The Helmand River is the only perennial river between the Indus and Tigris-Euphrates Rivers. A typical desert river, the Helmand is fed by melting snow from high mountains and infrequent storms. Great fluctuations in discharge-from tremendous floods to years of successive drought - can be expected. Intelligent management of water distribution for irrigation, power generation, and human consumption is essential in this arid environment. More than 50 years have passed since the Kajakai and Arghandab Dams were completed. Afghanistan can build on its vast experiences, good and bad, with irrigation and drainage schemes, land reform, agricultural methods, power requirements, and environmental costs to upgrade and to improve the water distribution system of the lower Helmand Basin. The reinvestment costs to upgrade dams and irrigations systems will be significant; however, improved water management in the lower Helmand Basin will be a critical element in the reconstruction of the country. 

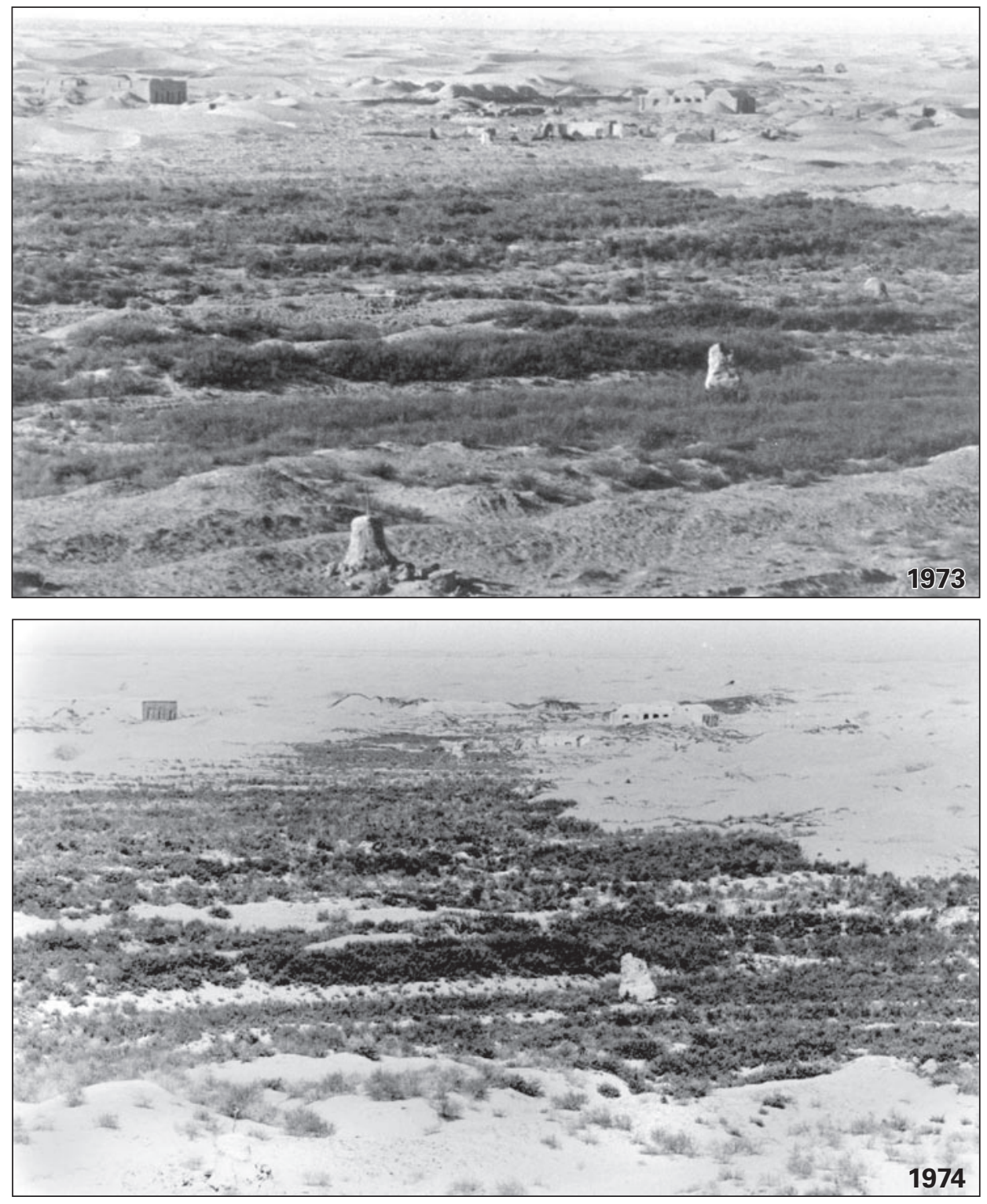

Figure 22. A small village on the Helmand River flood plain near Qala-i Fath at the head of the delta is engulfed by dunes.

\section{Acknowledgments}

The author acknowledges his original support from the Smithsonian Institution and from William Trousdale, the effective and insightful director of the Helmand-Sistan Project during the 1970s. The present study was prepared for the
USGS Afghanistan Project, which has been funded by the U.S. Agency for International Development (USAID) Mission in Kabul through an Interagency Agreement. The author appreciates careful reviews and suggestions by Michael Chornack, Patrick Tucci, and Thomas Judkins. Lisa Rukstales greatly improved the figures in this report and Mary Kidd enhanced the clarity of the text by her editing. 


\section{References Cited}

(hard-to-find references are marked with an*)

Abdullah, Shareq, 1979, The Chaman-Moqur fault: Tectonophysics, v. 52, p. 345-346.

Abdullah, J., Bordet, P., Carbonnel, J.-P., and Pias, J., 1975, Sur l'existence d'un dome récent de carbonatites dans le Registan: Comptes Rendus de l'Académie des Sciences Paris, v. 281, p. 1801-1804.

Afghan Institut de Meteorologie, 1971, Meteorological records of Afghanistan for 1970: Kabul, open-file data, 37 p. *Most of these data are summarized in U.S. Agency for International Development 1976 report on the Helmand Basin.

Allchin, Bridgit, and Goudie, A., 1978, Climatic change in the Indian Desert and north-west India during the late Pleistocene and early Holocene, in Brice, W.C., ed., The Environmental history of the Near and Middle East: London, Academic Press, p. 255-260.

Allchin, Bridget, Goudie, A., and Hedge, M., 1978, The prehistory and palaeogeography of the Great Indian desert: London, Academic Press, 339 p.

Anderson, A.O., 1973, Pleistocene geology and archeological problems of the Seistan Basin, southwest Afghanistan: Albuquerque, University of New Mexico, Master's thesis, $105 \mathrm{p}$.

Auden, J.B., 1974, Afghanistan-West Pakistan, in Spencer, A.M., ed., Mesozoic-Cenozoic orogenic belts: Geological Society of London, p. 235-253.

Balland, Viviane, and Lang, Jacque, 1974, Les rapports géomorphologique Quaternaires et actuels du bassin de Bamyan et de ses bordures montagneuses (Afghanistan central): Revue de géographie et de géologie dynamique, v. 16, p. $327-350$.

Barlow, Matthew, Cullen, H., and Lyon, B., 2002, Drought in central and southwest Asia: La Niña, the warm pool, and Indian Ocean precipitation: Journal of Climate, v. 15, p. 697-701.

Beaumont, Peter, Blake, G.H., and Wagstaff, J.M., 1976, The Middle East-A geographical study: London, Wiley, 572 p.

Becker, H., Forster, H., and Soffel, H.,1973, Central Iran, a former part of Gondwanaland-Paleomagnetic evidence from Infracambrian rocks and iron ores of the Bafq area, central Iran: Zeitschrift fur Geophysics, v. 38, p. 953-963.

Berberian, Manuel, 1976, The seismicity of Iran-Preliminary map of epicentres and focal depths: Tehran, Geological Survey of Iran, scale 1: 2,500,000.
Berberian, Manuel, 1981, Active faulting and tectonics of Iran, in Gupta, H.K., and Delany, F.M., eds., Zagros, Hindu Kush, Himalaya-Geodynamic evolution: Washington, D.C., American Geophysical Union and Geological Society of America (Boulder Geodynamic series), v. 3, p. 33-69.

Beun, Noel, Bordet, P., and Carbonnel, J.P., 1979, Premières données quantitatives Relatives au Coulissage du Décrochement de Chaman (Afghanistan du Sud-Est): Comptes Rendus de l'Académie des Sciences Paris, v. 288, p. 931-934.

Blanford, W.T., 1873, On the nature and probable origin of the superficial deposits in the valleys and deserts of central Persia: Geological Society of London Quarterly Journal, v. 29 , p. $493-503$.

Bobek, Hans, 1963, Nature and implications of Quaternary climatic changes in Iran: UNESCO-WHO Symposium on changes of climate, October 1961, Rome, p. 403-413.

Bobek, Hans, 1969, Zur Kenntnis der Sudlichen Lut: Mittlungen der Oesterreichischen Geographischen Gesellschaft, v. 3, p. 155-192.

Bottema, Sytze, 1978, The late glacial in the eastern Mediterranean and the Near East, in Brice, W.C., ed., The environmental history of the Near and Middle East: London, Academic Press, p. 15-28.

Bowler, J.M., 1978, Glacial age aeolian events at high and low latitudes-A southern perspective, in Van Zinderen Bakker, E.M., Antarctic glacial history and world palaeoenvironments: Rotterdam, A.A. Balkema, p. 149-172.

Brigham, R.H., 1964, Compilation of hydrologic data, Helmand River valley, Afghanistan, through September 1960: U.S. Geological Survey Open-File Report, 236 p.

Bureau of Reclamation, 1954, Drainage and related problems of irrigation development in the Helmand Valley of Afghanistan: Reconnaissance Report, Foreign Operations Administration, 35 p. (C.R. Maierhofer, writer) *Available at Bureau of Reclamation library, Denver, Colorado.

Butzer, K.W., 1978, The Late Prehistoric environmental history of the Near East, in Brice, W.C., ed., The environmental history of the Near and Middle East: London, Academic Press, p. 5-12.

Caudill, Mildred, 1969, Helmand-Arghandab Valley: USAID/ Afghanistan, Lashkar Gah, 70 p. * Available in libraries that are repositories for U.S. Government reports.

Childers, Dallas, 1974, Compilation of streamflow records, Helmand River valley and adjacent areas, Afghanistan, 1961-1968: U.S. Geological Survey Open-File Report (no number), $144 \mathrm{p}$. 
Clapp-Wincek, Cynthia, 1983, The Helmand Valley Project in Afghanistan: A.I.D. Evaluation Special Study no. 18, U.S. Agency for International Development PN-AAL-028, 29 p. *Available in libraries that are repositories for U.S. Government reports.

Conolly, E., 1840, Sketch of the physical geography of Seistan: Journal of the Asiatic Society of Bengal, v. 9, p. 710-726.

Conrad, Georges, and Conrad, J., 1970a, Le Tertiare continental des monts de Kerman et du Lout (Iran oriental): Comptes Rendus de l'Académie des Sciences Paris, v. 270, p. 1421-1423.

Conrad, Georges, and Conrad, J., 1970b, L'évolution quarternaire de la dépression du Lut (Iran oriental): Comptes Rendus de 1'Académie des Sciences Paris, v. 270, p. 1672-1674.

Costantini, Lorenzo, and Tosi, M., 1978, The environment of southern Sistan in the Third Millennium B.C., and its exploitation by the Proto-urban Hilmand civilization, in Brice, W. C., ed., The environmental history of the Near and Middle East: London, Academic Press, p. 165-182.

Cullather, Nick, 2002, Damming Afghanistan-Modernization in a buffer state: Journal of American History, v. 89, p. 512-537.

Degens, E.T., and Paluska, A., 1979, Tectonic and climatic pulses recorded in Quaternary sediments of the CaspianBlack Sea region: Sedimentary Geology, v. 23, p. 149-163.

Dickey, P.A., 1968, Contemporary nonmarine sedimentation in Soviet Central Asia: American Association of Petroleum Geologists Bulletin, v. 52, p. 2396-2421.

Dixon, Robyn, 2003, Opium production spreading in Afghanistan: Los Angeles Times, October 5, 2003, newspaper article.

Dupree, Louis, 1980 (1973 revised), Afghanistan: London, Oxford University Press, 804 p.

Ehlers, Eckart, 1971, Die historischen Spiegelschwankeungen des Kaspischen Meeres und Probleme ihrer Deutung: Erkunde, v. 25, p. 241-248.

Emiliani, Cesare, 1955, Pleistocene temperature variations in the Mediterranean: Quarternaria, v. 2, p. 87-98.

Enzel, Yahuda, Ely, L.L., Mishra, S., Ramesh, R., Amit, R., Lazar, B., Rajaguru, S.N., Baker, V., and Sandler, A., 1999, High-resolution Holocene environmental changes in the Thar Desert, northwestern India: Science, v. 284, p. $125-128$.

Fairbridge, R.W., 1961, Eustatic changes in sea level: Physics and chemistry of the earth, v. 4, p. 99-185.
Fairservis, W.A., 1961, Archaeological studies in the Seistan basin of southwestern Afghanistan and eastern Iran: New York, Anthropological Papers of the American Museum of Natural History, v. 58, p. 1-128.

Fisher, W.B., 1968, Physical geography, in Fisher, W.B., The land of Iran-The Cambridge history of Iran, I: Cambridge University Press, v. 1, p. 3-110.

Forster, Hansgeorg, 1976, Continental drift in Iran in relation to the Afar structures, in Pilger, A., and Rosler, A., eds., Afar between continental and oceanic rifting-Proceedings of an international symposium on the Afar region and related rift problems held in Bad Bergzabern, F. R. Germany, April 1-6, 1974: Stuttgart, E. Schweizerbart'sche Verlagsbuchhandlung, v. 2, p. 180-190.

Forster, Hansgeorg, 1978, Mesozoic-Cenozoic metallogenesis in Iran: Journal of the Geological Society of London, v. 135, p. $443-455$.

Freund, Raphael, 1970, Rotation of strike slip faults in Sistan, southeast Iran: Journal of Geology, v. 78, p. 188-200.

Ganji, M.H., 1968, The climate of Iran, in Fisher, W.B., ed., The land of Iran-The Cambridge history of Iran, I: Cambridge, University Press, p. 212-245.

Gansser, Augusto, 1971, The Taftan volcano (SE Iran): Ecologae Geologicae Helvetiaev, v. 64, no. 2, p. 319-334.

Gerasimov, I.P., 1978, Ancient rivers in the deserts of Soviet Central Asia, in Brice, W.C., ed., The environmental history of the Near and Middle East: London, Academic Press, p. 319-334.

Goldsmid, Sir Frederic, 1876, Eastern Persia: London, Macmillan and Co., 2 volumes.

Goudie, A.S., Allchin, B., and Hedge, K.T.M., 1973, The former extensions of the Great Indian Sand Desert: Geographical Journal, v. 139, p. 243-257.

Grotzbach, E., and Rathjens, C., 1969, Die heutige and jung Pleistozane Vergletcherung des Afghanischen Hindukush: Zeitschrift fur Geomorphologie, Supplement band 8, p. $58-75$.

Hedin, S.A., 1910, Zu Land nach Indien durch Persien, Seistan, Belutschistan: Leipzig, Brochaus, 2 volumes.

Holcombe, C.J., 1978, Intraplate wrench deformation in Iran, Afghanistan and western Pakistan: Geologische Rundschau, v. 67 , p. $37-48$.

Horvath, Eva, 1975, Glaciers of the Hindu Kush, in Field, W.O., Mountain glaciers of the northern hemisphere: Cold Regions Research and Engineering Laboratory, Hanover, N.H., v. 1, p. 361-370. 
Huntington, Ellsworth, 1905, The basin of eastern Persia and Sistan, in Pumpelly, Raphael, Explorations in Turkestan: Washington, D.C., Carnegie Institution, v. 26, 219-316.

International Engineering Company, 1972, Preliminary assessment of providing flood control in Chakhansur, Afghanistan: Report to the Asian Development Bank, Philippines, 134 p. *Available in Kabul at the Ministry of Water and Energy. IECO was the engineering company subsidiary of Morrison-Knudsen Corporation, which is the heritage company of Washington Group International.

Jux, Ulrich, and Kempf, K.E., 1983, Regional geology of Afghan Sistan, in Tosi, M., ed., Prehistoric Sistan: Rome, Istituto Italiano per il Medio ed EstremoOriente, Reports and Memoirs, v. 19, p. 5-60.

Kendrew, W.G., 1961, The climate of the continents: New York, Oxford University Press, 5th ed., 608 p.

Klootwijk, C.T. and Pierce, J.W., 1979, India's and Australia's pole path since the late Mesozoic and the India-Asia collision: Nature, v. 282, p. 605-607.

Krinsley, D.B., 1970, A geomorphological and paleoclimatological study of the playas of Iran: Bedford, Mass., U.S. Air Force Cambridge Research Laboratories, 486 p.

Krinsley, D.B., 1972, The paleoclimatic significance of Iranian playas: Paleoecology of Africa and of the surrounding islands and Antarctica, v. 6, p. 114-120.

Krumsiek, Klaus, 1976, Zur Bewegung der Iranisch-Afghanistan Platte: Geologische Rundschau, v. 65, p. 909-930.

Krumsiek, Klaus, 1980, Zur plattentectonischen Entwicklung des Indo-Iranischen Raumes (Resultate palaomagnetischer Untersuchungen in Afghanistan): Stuttgart, Geotektonische Forschungen, band 60, $223 \mathrm{p}$.

Lamb, H.H., 1977, Climate-Present, past and future: London, Methuen and Company, volume 2 (Climatic history and the future), $335 \mathrm{p}$.

Lang, H.O., 1971, Uber das Jungtertiar und Quartar in SudAfghanistan: Beihefte zum Geologischen Jahrbuch, heft 96, p. 167-208.

Lang, Jacques, 1975, Les bassins intramontagneux Cenozoiques de l'Afghanistan central: Nancy, Sciences de la Terre, Tome XX, no. 1, 115 p.

Lydolph, P.E., 1977, Climates of the Soviet Union: Amsterdam, Elsevier Scientific Publishing Co., p. 7-33 and 151-189.
McCauley, J.F., Grolier, M.J., and Breed, C.S., 1977, Yardangs, in Doehring, D.O., ed., Geomorphology in arid regions: Proceedings, 8th Annual Geomorphology Symposium, Binghamton, State University of New York, p. 233269.

McMahon, A.H., 1897, The southern borderlands of Afghanistan: Journal of the Royal Geographical Society, v. 19, p. 931-934.

McMahon, Henry, 1906, Recent survey and exploration in Seistan: Journal of the Royal Geographical Society, v. 28, p. 209-228 and 333-352.

Michel, A.A., 1972, The impact of modern irrigation technology in the Indus and Helmand Basins of southwest Afghanistan, in Farvar, M.T., and Milton, J.P., eds., The careless technology: Garden City, N.Y., Natural History Press, p. 257-275.

Middleton, N.J., 1986, A geography of dust storms in southwest Asia: Journal of Climatology, v. 6, p. 183-196.

Molnar, Peter, and Tapponnier, P., 1975, Cenozoic tectonics of Asia-Effects of a continental collision: Science, v. 189, p. 419-426.

Norin, Erik, 1932, Quaternary climatic changes in the Tarim Basin: Geographical Review, v. 107, p. 591-598.

Norin, Erik, 1941, Geological reconnaissance in Chinese Turkestan: Stockholm, Reports of the Sino-Swedish Expedition, publication no. 16, p. 186-190.

Nowroozi, A. A., 1972, Focal mechanism of earthquakes in Persia, Turkey, West Pakistan, and Afghanistan, and plate tectonics of the Middle East: Bulletin of the Seismological Society of America, v. 62, p. 823-850.

Nowroozi, A. A., 1976, Seismotectonic provinces of Iran: Bulletin of the Seismological Society of America, v. 66, p. 1249-1276.

Nyrop, R.F., and Seekins, D.M., eds., 1986, Afghanistan-A country profile: Washington, D.C., American University Foreign Area Studies, 408 p.

O'Leary, D.W., and Whitney, J.W., 2005a, Geological map of quadrangles 3062 and 2962, Charbuiak (609), Khannesin (610), Gawdezereh (615) and Galach (616), Afghanistan: U.S. Geological Survey Open-File Report 2005-1122A, scale 1:250,000.

O'Leary, D.W., and Whitney, J.W., 2005b, Geological map of quadrangles 3164, Lashkargah (605) and Kandahar (606), Afghanistan: U.S. Geological Survey Open-File Report 2005-1119A, scale 1:250,000. 
Paluska, Antonin, and Degens, E.T., 1979, Climatic and tectonic events controlling the Quaternary in the Black Sea region: Geologische Rundschau, v. 68, p. 284-301.

Partow, Hassan, 2003, Sistan oasis parched by droughts, in Atlas of global change: United Nations Environmental Programme, Oxford University Press, p. 144-145.

Perkins, D.C., and Culbertson, J.K., 1970, Hydrographic and sedimentation survey of Kajakai reservoir, Afghanistan: U.S. Geological Survey Water-Supply Paper 1608-M, 43 p.

Pias, Jean, 1972, Signification geologique, pedologique et paleoclimatique de formations paleolacustres et deltaiques au Seistan: Comptes Rendus de l'Academie des Sciences Paris, v. 274, p. 1143-1146.

Pias, Jean, 1974a, Genese de croutes et encroutements calcaires en Afghanistan au Quarternaire Recent: International Congress of Soil Sciences, Transactions, no. D, v. 6, pt. 2 (commission 5), p. 394-401.

Pias, Jean, 1974b, Pedogeneses et accumulations calcaires successives en Afghanistan au cours des quarante derniers millenaires: Comptes Rendus de l'Academie des Sciences Paris, v. 278, p. 2625-2621.

Pias, Jean, 1976, Formations superficielles et sols d'Afghanistan: Paris, Travaux et Documents de l'O.R.S.T.O.M. (Institut Français de Recherche Scientifique pour le Développement en Coopération), no. 55, 315 p.

Radermacher, Helmut, 1974, Historical irrigation systems in Afghan Sistan-Their origin, their decline and possibilities of their reconstruction: Annual Bulletin of the International Commission on Irrigation and Drainage, p. 34-42.

Radermacher, Helmut, 1976, Historische und gegenwartige Bewasserungssysteme, in Fischer, K., ed., NimruzArchaologische landesaufnahme in Sudwest Afghanistan: Bonn, Rudolf Habelt Verlag, p. 159-213.

Rawlinson, Henry, 1873, Notes on Seistan: Journal of the Royal Geographical Society, v. 43, p. 272-294.

Reeves, C.C., 1977, Intermontane basins of the arid western United States, in Doehring, D.O., ed., Geomorphology in arid regions: Binghamton, N.Y., 8th Annual Geomorphology Symposium proceedings, p. 7-25.

Schreiber, Alfred, Weippert, D., Wittekindt, H._P., and Wolfart, R., 1971, Geology and petroleum potentials of central and south Afghanistan: The American Association of Petroleum Geologists Bulletin, v. 56, p. 1494-1519.

Schulz, Erhard, and Whitney, J.W., 1986, Upper Pleistocene and Holocene lakes in the An Nafud, Saudi Arabia: Hydrobiologia, v. 143, p. 175-190.
Shareq, Abdullah, 1981, Geological observations and geophysical investigations carried out in Afghanistan over the period of 1972-1979, in Gupta, H.K., and Delany, F.M., Zagros, Hindu Kush, Himalaya-Geodynamic evolution: Washington, D.C., American Geophysical Union and Geological Society of America (Boulder), Geodynamic series, v. 3 , p. $75-86$.

Shareq, Abdullah, Chmyriov, V.M., Stazhilo-Alekseev, K.F., Dronov, V.I., Gannon, P.J., Lubemov, B.K., Kafarskiy, A.Kh., and Malyarov, E.P., 1977, Mineral resources of Afghanistan (2d ed.): Kabul, United Nations Development Programme, 429 p.

Singh, Gurdip, Joshi, R.D., and Singh, A.B., 1972, Stratigraphic and radiocarbon evidence for the age and development of three salt lake deposits in Rajastan, India: Quaternary Research, v. 2, p. 496-505.

Singh, Gurdip, Joshi, R.D., Chopra, S.K., and Singh, A.B., 1974, Late Quaternary history of vegetation and climate of the Rajastan desert, India: Philosophical transactions of the Royal Society, series B, v. 267, p. 467-501.

Sivall, T.R., 1977, Synoptic-climatological study of the Asian summer monsoon in Afghanistan: Geografiska Annaler, v. 59 , p. $67-87$.

Smith, G.I., 1974, Quaternary deposits in southwestern Afghanistan: Quaternary Research, v. 4, p. 39-52.

Soffel, Heinrich, Forster, H., and Becker, H., 1975, Preliminary polar wander path of Central Iran: Zeitschrift fur Geophysics, v. 41, p. 541-543.

Stein, Sir M.A., 1928, Innermost Asia-Detailed report of explorations in Central Asia, Kan-su, and eastern Iran: Oxford, Oxford University Press, 3 volumes.

Stocklin, Jovan, 1974, Possible ancient continental margins in Iran, in Burke, K., and Drake, C., eds., The geology of continental margins: New York, John Wiley, p. 873-887.

Stocklin, Jovan, Eftekhar-nezhad, J., and Hushmand-zadeh, A., 1972, Central Lut reconnaissance, east Iran: Tehran, Geological Survey of Iran, report no. 22, 61 p.

Street, F.A., and Grove, J., 1976, Late Quaternary lake level fluctuations in Africa-Environmental and climatic: Nature, v. 261, p. 385-390.

Sykes, P.M., 1902, Ten thousand miles in Persia, or eight years in Iran: London, John Murray, 481 p.

Takahashi, Koichiro, and Arakawa, H., ed., 1981, Climates of southern and western Asia: Elsevier Publishing Company (World Survey of Climatology, v. 9), 333 p. 
Tate, G.P., 1910-12, Seistan, A memoir on the topography, ruins, and people: Calcutta, Superintendent of Printing, 4 volumes, 374 p. *Available at a few American research libraries.

Taylor, G.C., 1976, Historical review of the international water-resources program of the U.S. Geological Survey, 1940-70: U.S. Geological Survey Professional Paper 911, p. 62-65.

Thunnell, R.C., 1979, Eastern Mediterranean Sea during the last glacial maximum-An 18,000-years B.P. reconstruction: Quaternary Research, v. 11, p. 353-372.

Tosi, Maurizo, 1973, L'industria litica e italiana; lavorazione degli element, di collana a Shahr-i-Sokhta (Iran): GeoArcheologia, v. 1, p. 23-29.

Tosi, Maurizo, 1976, A topographical and stratigraphical periplus of Sahr-e Suxteh, in Bagherzadeh, F., ed.: Proceedings of the 4th Annual Symposium an Archeological Research in Iran, 3-8 November, Tehran, 1975, p. 130-158.

Trifonov, V.G., 1978, Late Quaternary tectonic movements of western and central Asia: Geological Society of America Bulletin, v. 89, p. 1059-1072.

United Nations Educational, Scientific, and Cultural Organizations, 1979, Map of the world distribution of arid regions-Man and the biosphere technical notes no. 7: Paris, UNESCO, 54 p.

United Nations Environment Programme, 2003, Afghanistan-Post conflict assessment: Switzerland, United Nations Environment Programme, 180 p.

United Nations Environment Programme, 2006, History of environmental change in the Sistan Basin based on satellite image analysis, 1976-2005: Geneva, Switzerland, United Nations Environment Programme, 56 p.

U.S. Agency for International Development, 1976, Helmand River Basin-Soil and water survey study report: Open File Report in Kabul, 180 p. *Available in Kabul at the Ministry of Water and Energy library.

Van Zeist, Willem, and Bottema, S., 1977, Palynological investigations in western Iran: Palaeohistoria, v. 19, p. $19-85$.

Van Zeist, Willem, and Bottema, S., 1982, Vegetational history of the eastern Mediterranean and Near East during the last 20,000 years, in Bintliff, J.L., and Van Zeist, W., eds., Paleoclimates, paleoenvironments and human communities in the eastern Mediterranean region in later prehistory: Oxford, British Archeological Reports, v. 133 (part 2), p. 277-321.
Velichko, A.A., 1984, Late Pleistocene spatial paleoclimatic reconstructions, in Velichko, A.A., ed., Late Quaternary environments of the Soviet Union: Minneapolis, University of Minnesota Press, p. 261-285.

Vikhter, B. Ya., Yeremenko, G.K., Chmyrev, V.M., and Abdullah, D., 1978, Pliocene-Quaternary volcanism of Afghanistan: International Geology Review, v. 20, p. 525-536.

Walter, Heinrich, 1973, Vegetation of the earth (translated by J. Wieser): New York, Springer-Verlag, 237 p.

Ward, T.R.J., 1906, Seistan-Revenue reports and notes (vol. 1), Irrigation report (vol. 2): Simla, India, Government Central Printing Office. *Available in Great Britain.

Weippert, Dietrich, Wittekindt, H., and Wolfart, R., 1970, Zur geologischen Entwicklung von Zentral- und Sudafghanistan: Kabul, Beihefte zum Geologischen Jahrbuch, heft 92 , $99 \mathrm{p}$.

Wellman, H.W., 1966, Active wrench faults of Iran, Afghanistan, and Pakistan: Geologische Rundschau, band 55, p. 716-735.

Wheeler, R.L., Bufe, C.G., Johnson, M.L., and Dart, R.L., 2005, Seismotectonic map of Afghanistan, with annotated bibliography: U.S. Geological Survey Open-File Report 2005-1264, 31 p.

Whitney, J.W., 1983, Erosional history and surficial geology of western Saudi Arabia: Jiddah, Kingdom of Saudi Arabia, Deputy Ministry of Mineral Resources Technical Record TR-04-01, 90 p. (U.S. Geological Survey Interagency Report 621). *Available at U.S. Geological Survey library.

Whitney, J.W., Faulkender, D.J., and Rubin, M., 1983, The environmental history and present condition of the Saudi Arabia's northern sand seas: U.S. Geological Survey OpenFile Report 83-749, 42 p.

Whitney, J.W., and Trousdale, W., 1982, Catastrophic floods, wind erosion, and historical occupation on the Helmand River delta, southwest Afghanistan: American Quaternary Association, 7th biennial conference, June 28-30, Seattle, Wash., p. 180.

Whitney, J.W., and Trousdale, W., 1984, Man versus sand in southwest Afghanistan: Geological Society of America Abstracts with Programs, v. 16, no. 7, p. 693.

Williams, M.A.J., and Faure, H., eds., 1980, The Sahara and the Nile: Rotterdam, A. A. Balkema, 607 p.

Wittekindt, Hans, and Weippert, D., compilers, 1973, Geologische Karte von Zentral- und Sudafghanistan: Hannover, Bundesanstalt fur Bodenforschung, 4 sheets, scale 1:500,000. 
Woodruff, S.A., and Horton, B.P., 2005, Holocene sea-level changes in the Indo-Pacific: Journal of Asian Earth Sciences, v. 25, p. 29-43.
Zakhilwal, Omar, 2004, The Helmand Valley Project: Institute for Afghan Studies, archived article at http://www.institutefor-afghan-studies.org/Foreign\%20Affairs/us-afghan/ helmand_0.htm (accessed Oct. 3, 2005).

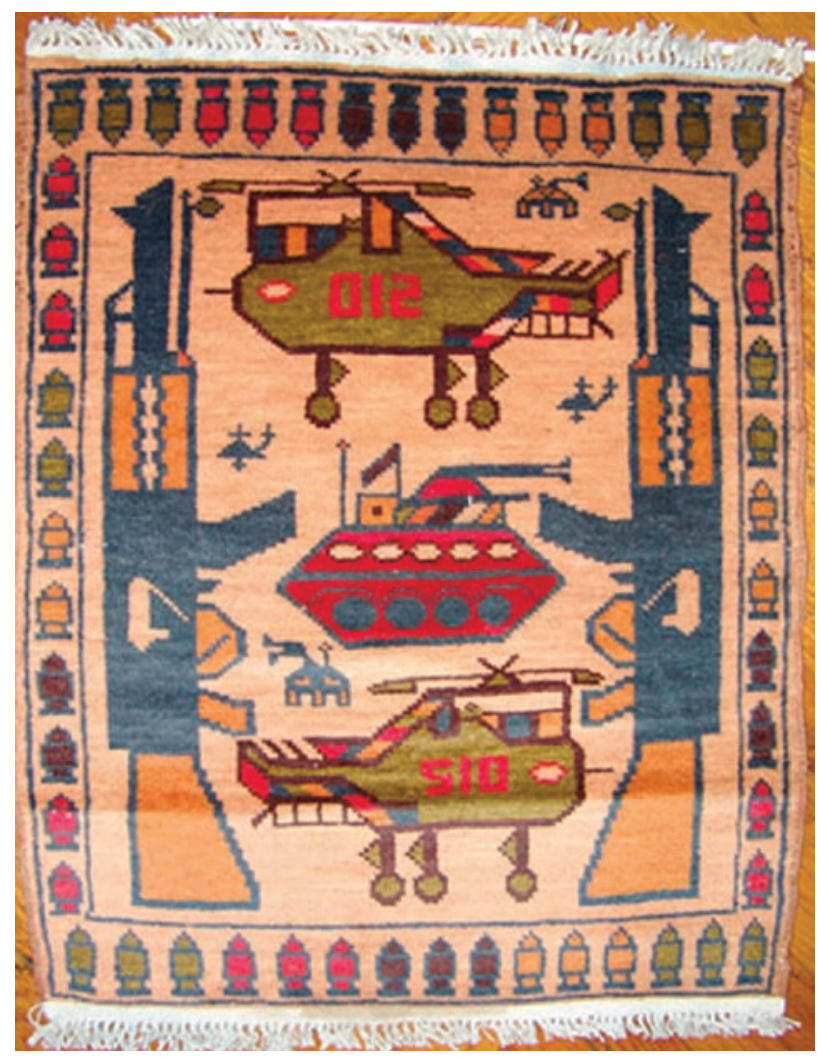

Over 25 years of war and political strife have left an indelible impact on the Afghan people and have become a common theme in their famed handmade carpets. 
Back cover photograph: Spring and oasis on the alluvial fan that drains northward into the Gaud-i Zirreh at Kirtaka in Pakistan. 


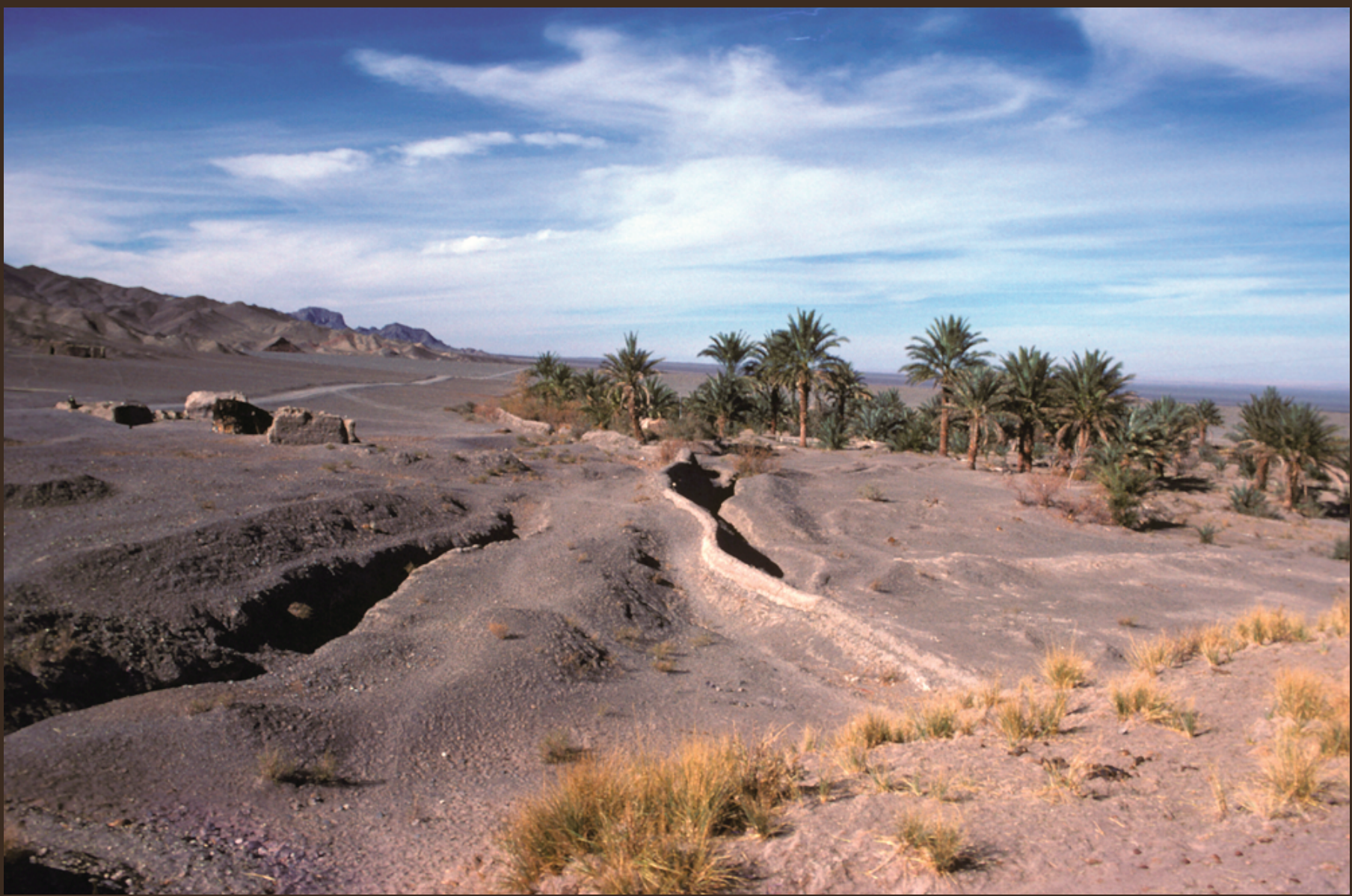

疍

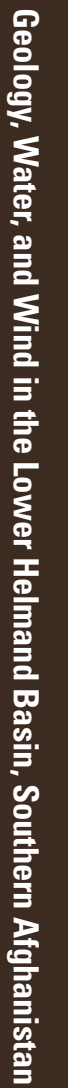

量

